Department of Internal Medicine I, University Hospital Ulm,

Prof. Dr. Seufferlein

\title{
Hepcidin knockout mice as a model of iron-overload associated liver disease
}

Dissertation presented to the Medical Faculty of Ulm University

to obtain the degree Doctor of Human Biology

Mariia Lunova

Leninakan, Armenia

2013 
Current Dean: Prof. Thomas Wirth

Thesis reviewers:

$1^{\text {st }}$ reviewer: PD Dr. Pavel Strnad

$2^{\text {nd }}$ reviewer: Prof. Thomas Simmet

Date of doctorate awarded: 08.11.13 


\section{Table of contents}

ABBREVIATIONS _ 5

1 INTRODUCTION _

1.1 Iron homeostasis _ 7

1.2 The role of hepcidin in iron homeostasis __ 7

1.3 Hepcidin - Ferroportin interaction and cellular iron release ___ 9

1.4 Iron overload disorders. Role of hepcidin in iron overload __ 9

1.4.1 The role of hepcidin in iron overload disorders ___ 9

1.4.2 Hereditary hemochromatosis $(\mathrm{HH}) \_12$

1.4.3 Secondary hemochromatosis $(\mathrm{SH}) \ldots 13$

1.5 Iron redistribution and storage _ـ 15

1.5.1 Plasma iron and mechanism of cellular iron uptake___ 15

1.5.2 Storage of intracellular iron ___ 17

1.6 Iron toxicity via reactive oxygen species (ROS). Mechanism of oxidative liver fibrosis development _ـ 18

2 AIMS OF THE STUDY__ 21

3 MATERIAL AND METHODS___ 22

3.1 Animal experiments___ 22

3.2 Deoxyribonucleic acid (DNA) isolation ___ 22

3.3 Mouse genotyping _ 23

3.4 Agarose gel electrophoresis___ 24

3.5 Western Blot___ 24

3.6 Subcellular fractionation___ 26

3.7 Hydroxyproline assay __ 28

3.8 Serum enzymes concentrations and serum iron parameters __ 28

3.9 Tissue staining __ 28

3.10 Perls' Prussian Blue staining __ 29

3.11 Picro-Sirius-Red (PSR) staining __ 29

3.12 Haematoxylin and Eosin staining (H\&E) ___ 30

3.13 Immunohistochemical staining ___ 30

3.14 DNA damage staining ___ 31

3.15 Electron microscopy staining (EM) ___ 32

3.16 Determination of nonheme hepatic iron ___ 32

3.17 Determination of Non Transferrin Bound Iron (NTBI) _ 33

3.18 Ribonucleic acid (RNA) isolation___ 33 
3.19 Reverse transcription

3.20 Quantitative real - time PCR (RT - PCR) _ 34

3.21 Statistical analysis ___ 35

3.22 Materials _ 35

4 RESULTS

4.1 Phenotypic analysis of Hepcidin 1 knockout mouse

4.2 Experimental iron overload model

4.3 6 months old hepcidin knockout mice on iron-rich diet display elevated transaminases levels _ 49

4.4 Hepcidin knockout mice show elevated serum iron parameters 50

4.5 Accelerated and ubiquitous iron accumulation in 6 months old hepcidin knockout mice fed ironrich diet

4.6 6 months old hepcidin knockout mice develop mild liver injury

4.7 6 months old hepcidin knockout mice fed iron-rich diet display a mild chronic elevated expression of inflammatory cytokines

4.8 Hepcidin knockout mice on iron-rich diet display elevated liver apoptosis

4.9 6 months old hepcidin knockout mice fed iron-rich diet show signs of hepatic stellate cells activation, but no significant liver fibrosis

4.10 12 months old, iron-rich diet fed hepcidin knockout mice develop moderate liver injury _ 58

4.11 Hepcidin knockout mice develop progressive iron overload at 12 months 59

4.12 Hepcidin knockout mice show dramatic deposition of iron in liver 61

4.13 12 months old hepcidin knockout mice kept on iron-rich diet develop significant liver fibrosis

4.14 Hepcidin knockout mice show accumulation of iron in cytoplasm, mitochondria and lysosomes

4.15 6 months old hepcidin knockout mice fed iron-rich diet display large iron-containing complexes within lysosomes

4.16 Hepcidin knockout mice show downregulation of STEAP3 and DMT1 68

4.17 Hepcidin knockout mice display elevated ferritin _ 70

4.18 Chronic iron overload leads to lysosomal damage in 6 months old hepcidin knockout mice fed iron - rich diet

4.19 Hepcidin knockouts fed with iron-rich diet for 5 months show an altered autophagy activation

4.20 Hepcidin knockout mice display an elevated oxidative DNA damage 


\section{Abbreviations}

ALD Alcoholic Liver Disease

ALC Alcoholic Liver Cirrhosis

ALT Alanine Transaminase

AP Alkaline Phosphotase

AST Aspartate Transaminase

ATP Adenosine triphosphate

BSA Bovine Serum Albumin

BPT Bathophenantrolinedisulfonic acid disodium salt hydrate

cDNA Complementary Deoxyribonucleic Acid

CTGF Connective Tissue Growth Factor

DAB Diaminobenzidine

DMT1 Divalent Metal Transporter 1

DNA Deoxyribonucleic Acid

dNTP Deoxyribonucleotide

ECM Extra Cellular Matrix

EPON Epoxy Resin

ER Endoplasmatic Reticulum

$\mathrm{Fe}-\mathrm{S} \quad$ Iron-Sulfur

FeNTA Iron III Nitrotriacetic Acid

FTH1 Ferritin Heavy Polypeptide 1

$\mathrm{H}_{2} \mathrm{O}_{2} \quad$ Hydrogen Peroxide

H\&E Haematoxylin and Eosin

HCV Hepatitis C Virus

HDAC2 Histone Deacetylase 2

HGF Hepatocytes Growth Factor

$\mathrm{HH}$ Hereditary Hemochromatosis

HNE 4-hydroxynonenal

HSC Hepatic Stellate Cells

Hsc70 Constitutively Expressed Chaperone 70

Hsp60 Heat Shock Protein 60

HRP Horseradish Peroxidase

ICAM Intracellular Adhesion Molecule

IHC Immunohistochemistry 


$\begin{array}{ll}\text { KO } & \text { Knockout } \\ \text { LC3 } & \text { Light Chain } 3 \\ \text { MCP1 } & \text { Monocyte Chemoattractant Protein 1 } \\ \text { MDA } & \text { Malondialdehyde } \\ \text { NTBI } & \text { Non Tranferrin Bound Iron } \\ \text { PAGE } & \text { Polyacrylamide Gel Electrophoresis } \\ \text { PBS } & \text { Phosphate Buffered Saline } \\ \text { PCR } & \text { Polymerase Chain Reaction } \\ \text { PDGF } & \text { Platelet Derived Growth Factor } \\ \text { POD } & \text { Peroxidase } \\ \text { PSR } & \text { Pico Sirius Red } \\ \text { PVDF } & \text { Polyvinylidene Difluoride } \\ \text { RNA } & \text { Ribonucleic Acid } \\ \text { ROS } & \text { Reactive Oxygen Species } \\ \text { RT } & \text { Room Temperature } \\ \text { SDS } & \text { Sodium Dodecyl Sulphate } \\ \text { SD } & \text { Standard Deviation } \\ \text { SEM } & \text { Scanning Electron Microscope } \\ \text { SH } & \text { Secondary Hemochromatosis } \\ \text { TBA } & \text { Thiobarbituric Acid } \\ \text { TBST } & \text { Tris Buffered Saline containing 0,1\% Tween } \\ \text { TEM } & \text { Transmission Electron Microscope } \\ \text { TEMED } & \text { 1,2-Bis(dimethylamino)ethane } \\ \text { TdT } & \text { Terminal Deoxynucleotidyl Transferase } \\ \text { TF } & \text { Transferrin } \\ \text { TFR1 } & \text { Transferrin Receptor 1 } \\ \text { TFR2 } & \text { Transferrin Receptor 2 } \\ \text { TGFB } & \text { Transforming Growth Factor } ß \\ \text { Transferrin Saturation } \\ \text { Western Blot } \\ \text { Wild Type } \\ \text { WB }\end{array}$




\section{Introduction}

\subsection{Iron homeostasis}

Iron is an essential element which plays an important role in growth and survival, since it is necessary for various cellular processes such as DNA synthesis and repair, regulation of transcription, mitochondria respiration, or oxidative phosphorylation, and other enzymatic functions [1]. It is also required for iron sulphur clusters synthesis (iron sulphur clusters participate in electron transport, catalysis and regulatory processes of the cell) [2], haem synthesis and ferritin production [1,3]. The most important function of iron is to accept and donate electrons, thereby enabling oxygen transport $[1,4]$ and generation of adenosine triphosphate (ATP). The human body contains $4-5 \mathrm{~g}$ of iron [5] which is found mainly as haem in haemoglobin of erythroid cells ( $>2 \mathrm{~g}$ ) or myoglobin in muscles (about $300 \mathrm{mg}$ ). Macrophages from spleen, liver, and bone marrow harbour the transient iron fraction which totals approximately $600 \mathrm{mg}$, while approximately $1000 \mathrm{mg}$ of iron is stored in parenchymal cells in the form of ferritin [6]. Among the parenchymal cells, liver hepatocytes represent the major iron - storing cells. $1-2 \mathrm{mg}$ of the iron is lost every day through excretion via urins, faces, sweat etc as well as physiological blood loss [7]. Lost amount of iron needs to be replaced with iron absorbed from intestine [8]. In fact, intestinal iron uptake represents the only way to regulate iron metabolism and this regulation is executed by hepcidin, the central iron regulator.

\subsection{The role of hepcidin in iron homeostasis}

Hepcidin was first isolated from plasma and urine filtrates by A. Krause in 2000 [9] and C. H. Park in $2001[10,11]$. The gene encoding hepcidin (HAMP) resides at chromosome 19q13 and encodes an 84 amino acid long precursor termed preprohepcidin. After two cleavage steps, the final 25 amino acid long hepcidin is found. Hepcidin exerts its function through binding and subsequent internalization and degradation of ferroportin, the only 
known iron exporter [12]. Thereby iron export from the intestine into blood, the release of iron from macrophages and hepatocytes (Figure 1.1) [13]. Liver hepatocytes represent the predominant source of hepcidin synthesis and hepcidin production is regulated by iron demand [14]. In case of iron abundance, hepcidin concentration increases and limits further iron absorption $[15,16]$. On the other hand, in case of iron deficiency, hepcidin expression decreases and thereby permits an unrestricted release of iron from the intestine to the plasma $[16,17,18,19,20]$. However the regulation of hepcidin expression is very complex and increases in response to many processes such as infection and inflammation (via IL - 6 STAT3 signalling pathway) or hypoxia [21].

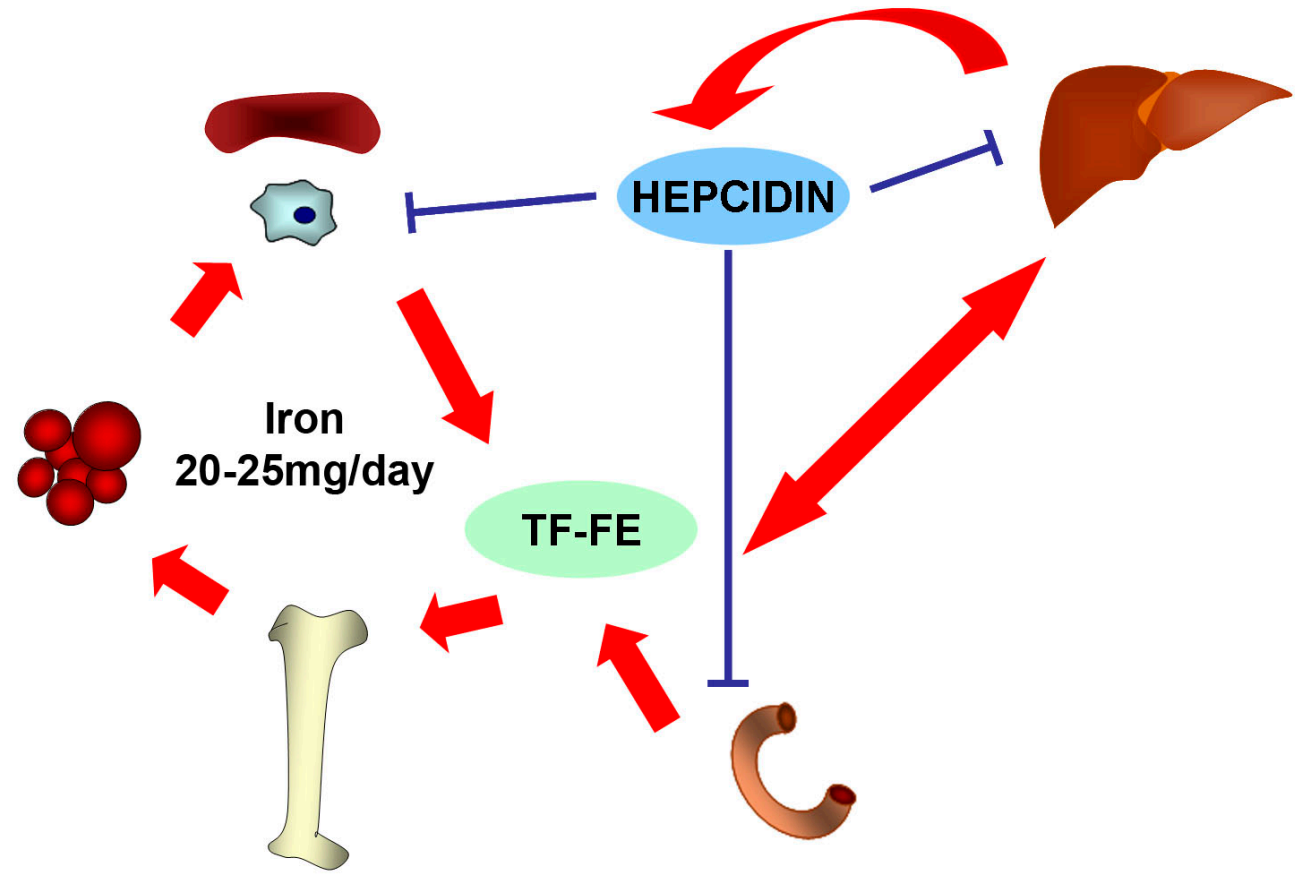

Figure 1.1. Iron distribution in human body. Human body contains about $4-5 \mathrm{~g}$ of iron. The majority of the iron is found in haemoglobin of circulating red blood cells. Approximately $20-30 \%$ of body iron is stored in hepatocytes and reticuloendothelial macrophages bound to ferritin or hemosiderin. Hepcidin is the major regulator of iron metabolism which controls iron release from intestine, macrophages, and hepatocytes. 


\subsection{Hepcidin - Ferroportin interaction and cellular iron release}

It has been shown that binding of hepcidin to ferroportin leads to phosphorylation, internalization, ubiquitination, and finally to lysosomal degradation of ferroportin [22,23]. The $5 \mathrm{~N}$ - terminal amino - acid of hepcidin residues are needed for this interaction $[22,24,25]$. In situations of high hepcidin production, iron is located within the enterocytes and is lost through desquamation of cells into the gut lumen. Ferroportin is also expressed by macrophages and, thereby, hepcidin plays a key role in iron recycling [26]. To that end, senescent red blood cells are phagocytosed by macrophages, iron liberated from haem, and this iron is brought back to the bloodstream via ferroportin, where it is bound to transferrin and redistributed into different tissues. Ferroportin is also found in hepatocytes, the liver parenchymal cells [27]. In summary, hepcidin regulates the amount of ferroportin and release of iron from multiple different cells; and patients in whom the hepcidin ferroportin interaction is disrupted due to ferroportin mutation, Kupffer cells contain increased amount of iron (Table 1.1).

\subsection{Iron overload disorders. Role of hepcidin in iron overload}

\subsubsection{The role of hepcidin in iron overload disorders}

Multiple human conditions result in a dramatic iron overload, which is typically caused by a dysfunction in hepcidin signalling, inappropriately low hepcidin production and/or exogenous iron supply mainly due to repeated blood transfusions. Such an iron overload can damage multiple tissues and lead to many symptoms such as: diabetes, cardiomyopathy, arthritis, bronze pigmentation of the skin, and liver cirrhosis [28]. Mutations in hepcidin or several hepcidin - related genes including HFE, TFR2, and HJV lead to an inherited iron overload and this group of diseases is termed hereditary hemochromatosis $(\mathrm{HH})$. To that end, under normal conditions, the membrane proteins HFE, TFR2, and HJV form a multi - protein membrane complex required for hepatic production of iron hepcidin [29]. Consequently, a defect in HFE [30], TFR2, and HJV 
leads to diminished hepcidin expression and results in iron overload (Table 1.1) [28,31]. Mutations in HFE are the most common form of $\mathrm{HH}$ accounting for $>85 \%$ of $\mathrm{HH}$ cases, with mutations in HJV or hepcidin resulting in particularly severe diseases [28]. Secondary or acquired iron overload usually develops as a result of repeated blood transfusions [32], and/or due to non - physiologically low hepcidin production in hepatic disorders such as hepatitis $\mathrm{C}$ or alcoholic liver disease [33,34]. Every millilitre of transfused blood adds about $0,47 \mathrm{mg}$ of iron [35]. In addition, anemia is known to decrease hepcidin production thereby triggering absorption of iron from intestine [19,32]. Therefore, patients with multiple blood transfusions eventually develop iron overload. 
Table 1.1. The role of hepcidin in selected human disorders. Black font HH; Blue font SH.

\begin{tabular}{|c|c|c|c|}
\hline Disorder & $\begin{array}{l}\text { Gene name; } \\
\text { chromosomal } \\
\text { location }\end{array}$ & Gene function & $\begin{array}{l}\text { Hepcidin and } \\
\text { consequences }\end{array}$ \\
\hline $\begin{array}{l}\text { Hereditary } \\
\text { Hemochromatosis } \\
\text { Type I }\end{array}$ & HFE; $6 \mathrm{p} 21.3$ & $\begin{array}{l}\text { Interaction with transferrin } \\
\text { receptor 1; uptake of transferrin } \\
\text { bound iron; modulation of } \\
\text { hepcidin expression }\end{array}$ & $\begin{array}{l}\text { Low or inappropriately } \\
\text { normal; iron overload } \\
\text { in liver, endocrine } \\
\text { glands, heart }\end{array}$ \\
\hline $\begin{array}{l}\text { Juvenile Hereditary } \\
\text { Hemochromatosis } \\
\text { Type II A }\end{array}$ & HJV; 1q21 & $\begin{array}{l}\text { Co - receptor of BMP, interacts } \\
\text { with BMP6; modulation of } \\
\text { hepcidin expression }\end{array}$ & $\begin{array}{l}\text { Low or inappropriately } \\
\text { normal; iron overload } \\
\text { in liver, endocrine } \\
\text { glands, heart }\end{array}$ \\
\hline $\begin{array}{l}\text { Juvenile Hereditary } \\
\text { Hemochromatosis } \\
\text { Type II B }\end{array}$ & HAMP; 19q13.1 & $\begin{array}{l}\text { Up - regulation of iron release by } \\
\text { enterocytes, macrophages, and } \\
\text { placental cells. }\end{array}$ & $\begin{array}{l}\text { Hepcidin } \\
\text { dysfunctional iron } \\
\text { overload in liver, } \\
\text { endocrine glands, heart }\end{array}$ \\
\hline $\begin{array}{l}\text { TFR2 related } \\
\text { Hereditary } \\
\text { Hemochromatosis Type } \\
\text { III }\end{array}$ & TFR2; 7q22 & $\begin{array}{l}\text { Possibly uptake of iron by } \\
\text { hepatocytes; precise role of TFR } 2 \\
\text { remains unclear }\end{array}$ & $\begin{array}{l}\text { Low or inappropriately } \\
\text { normal; iron overload } \\
\text { in liver, endocrine } \\
\text { glands, heart }\end{array}$ \\
\hline $\begin{array}{l}\text { Ferroportin disease } \\
\text { Type IV }\end{array}$ & SLC40A1; 2q32 & $\begin{array}{l}\text { Ferroportin - iron transporter, } \\
\text { regulated by hepcidin. Export of } \\
\text { iron from enterocytes, } \\
\text { macrophages, placental cells, or } \\
\text { hepatocytes }\end{array}$ & $\begin{array}{l}\text { Depending on the } \\
\text { mutation site, may lead } \\
\text { to iron - deficiency or } \\
\text { iron overload }\end{array}$ \\
\hline $\begin{array}{l}\text { Iron - refractory iron } \\
\text { deficiency anemia }\end{array}$ & $\begin{array}{l}\text { TMPRSS6; } \\
22 \mathrm{q} 12.3\end{array}$ & $\begin{array}{l}\text { TMPRSS6 gene, which encodes } \\
\text { the serine-protease matriptase } 2 \\
{[36] \text { an inhibitor of hepcidin }} \\
\text { production }\end{array}$ & $\begin{array}{l}\text { High level of hepcidin; } \\
\text { iron deficiency }\end{array}$ \\
\hline Hypotransferrinemia & $\begin{array}{l}\text { Transferrin } \\
(\mathrm{TF}) ; 3 \mathrm{q} 22.1\end{array}$ & $\begin{array}{l}\text { Binds and transport iron from the } \\
\text { intestine, reticuloendothelial } \\
\text { system, and liver parenchymal } \\
\text { cells to all proliferating cells in the } \\
\text { body }\end{array}$ & $\begin{array}{l}\text { Low level of hepcidin, } \\
\text { anemia, iron overload } \\
\text { in liver and heart }\end{array}$ \\
\hline $\begin{array}{l}\beta-\text { Thalassemia } \\
\text { intermedia }\end{array}$ & $\begin{array}{l}\beta-\text { Globin; } \\
11 \mathrm{p} 15.5\end{array}$ & $\begin{array}{l}\text { Mutant } \beta \text { - globin causes sickle cell } \\
\text { anemia }\end{array}$ & $\begin{array}{l}\text { Low level of hepcidin } \\
\text { due to anemia }\end{array}$ \\
\hline $\begin{array}{l}\text { Chronic Hepatitis C, } \\
\text { alcoholic liver disease }\end{array}$ & & $\begin{array}{l}\text { Inappropriately low hepcidin } \\
\text { production }\end{array}$ & $\begin{array}{l}\text { Hepcidin } \\
\text { decreased }\end{array}$ \\
\hline $\begin{array}{l}\text { Anemia of } \\
\text { inflammation }\end{array}$ & & $\begin{array}{l}\text { Inappropriately high hepcidin } \\
\text { production due to IL }-6 \text { signalling }\end{array}$ & $\begin{array}{l}\text { High level of hepcidin, } \\
\text { despite anemia and } \\
\text { hypoferremia }\end{array}$ \\
\hline $\begin{array}{l}\text { Anemia of chronic } \\
\text { kidney diseases }\end{array}$ & & $\begin{array}{l}\text { Hepcidin inappropriately high due } \\
\text { to ongoing inflammation }\end{array}$ & $\begin{array}{l}\text { High level of hepcidin, } \\
\text { despite anemia and } \\
\text { hypoferremia }\end{array}$ \\
\hline $\begin{array}{l}\text { Alcoholic Liver } \\
\text { Cirrhosis }\end{array}$ & & $\begin{array}{l}\text { Inappropriately low hepcidin } \\
\text { production }\end{array}$ & $\begin{array}{l}\text { Hepcidin } \\
\text { decreased }\end{array}$ \\
\hline
\end{tabular}




\subsubsection{Hereditary hemochromatosis (HH)}

The most common inherited disorder of iron metabolism is the HH type I. It constitutes an autosomal recessive disease with mutation in HFE gene. HFE is located at chromosome 6p and encodes an atypical major histocompatibility complex (MHC) class I type molecule [31,37]. Majority of patients with type I HH have point mutation in exon 4 of HFE gene that results in substitution of tyrosine for cysteine at position 282 of HFE protein (C282Y) [28,37]. Other patients are compound heterozygote for C282Y / H63D HFE mutations which result in a mild phenotype. Homozygous $\mathrm{C} 282 \mathrm{Y}$ mutation represents one of the most common inherited disorders and are found in people of Northern European origin [38,39]. In the US HFE C282Y mutation is responsible for $80-90 \%$ of hemochromatosis cases [40]. While homozygotes for C282Y mutation frequently all develop a multiple organ iron overload as a marker [41], the percentage of the disease (i.e. occurrence of clinical symptoms) is relatively low [42]. Similarly, HFE C282Y mutation leads to marked iron overload in mice, however it does not typically lead to tissue damage under basal conditions [43]. The H63D variant is even more common and is found in $15-40 \%$ of Caucasians, however homozygous presence of H63D variant is not sufficient to cause disease development [44]. On the other hand, compound heterozygotes C282Y / H63D may develop a disease although the phenotype is milder than the one seen in homozygous HFE C282Y carriers [45]. Reports of several groups show that the disease development in HFE C282Y carriers correlates with the extent of iron overload, albeit this correlation is imperfect $[46,47]$. The second most common $\mathrm{HH}$ form is due to homozygous mutation in the gene encoding the transferrin receptor 2 (TFR2) and was first described in 2000 by Camaschella [48]. Although the role of TFR2 in iron mechanism is incompletely understood, current evidence suggests that TFR2 is involved in cellular iron regulation rather than in iron uptake [49]. TFR2 related hemochromatosis shows relatively late development $\left(3^{\text {rd }}-4^{\text {th }}\right.$ decade of the life) and can lead to heart disease, endocrine disorders 
as well as liver damage [50,51]. The most severe type of $\mathrm{HH}$ is also known as a juvenile hemochromatosis $(\mathrm{JH})$. It represents an autosomal recessive disorder with severe iron accumulation and disease development in 15 - 20 years old subjects [52]. In addition to elevated transferrin saturation (TS), serum iron, and serum ferritin levels, the patients display impotence and cardiomyopathy. $\mathrm{JH}$ might be caused by mutations in the gene coding for HJV (more common, type 2A HH) or HAMP (less common, type 2B HH) [52,53]. In agreement with that, HJV as well as hepcidin knockout mice develop severe iron overload phenotype [54]. Mutations in ferroportin gene (SLC40A1) causes HH type IV which is also known as 'ferroportin disease' [55]. The phenotype of 'ferroportin disease' typically includes elevated serum ferritin level and low or normal transferrin saturation. Dependent on the position of ferroportin mutation, these mutations can lead either to diminished ferroportin levels resulting in macrophages iron overload or to hepcidin resistance (i. e. elevated ferroportin levels) with hepatocellular iron overload $[22,25,56]$. 'Ferroportin disease' is inherited in autosomal - dominant manner, is typically less severe than HFE but display a large variability dependent on the underlying mutation [57].

\subsubsection{Secondary hemochromatosis $(\mathrm{SH})$}

The term Secondary Hemochromatosis $(\mathrm{SH})$ describes a heterogeneous group of disorders, in which the development of iron overload is not due to an inherited mutation in a gene involved in iron methabolism. ß-thalassemia represents probably the best known cause of SH and with at least 60000 individuals being born every year [58,59]. $\beta$-thalassemia arise B - globin gene which results in its reduced synthesis, ineffective erythropoiesis and deregulation of iron metabolism lead to iron overload due to the need for multiple blood transfusions and increased intestinal iron absorption. Together with the massive haemolysis, iron overload causes accumulation of Non Transferrin Bound Iron (NTBI) which contributes to the observed damage in multiple tissues such as spleen, liver 
(predominantly hepatocytes), and bone marrow [60,61]. Several researchers showed that despite the presence of iron overload, hepcidin remains low in patients with $\beta$ - thalassemia probably because of the anemia which inhibits hepcidin production [62]. Of note, a crossbreeding of thalassemia mice with homozygous Tmprss6 significantly improved the phenotype of the mice and increased their life span [63]. Another two common disorders which are associated with hepatic iron overload are chronic Hepatitis C Virus (HCV) infection [33] and Alcoholic liver disease (ALD) [34,64]. HCV and ALD represent two abundant chronic liver diseases which may lead to development of liver cirrhosis and hepatocellular carcinoma thereby causing a significant mortality and mobility. It has been reported by Friedmann in 1988 that patients with ALD have twice increased intestinal iron absorption which leads to elevation of serum iron markers even at early age and iron accumulation in liver (predominantly periportal hepatocytes and later in Kupffer cells) [34]. Iron accumulation in ALD is typically relatively mild, but increase with development of cirrhosis. The pathomechanism of iron accumulation in patients with ALC is not completely understood, but it seems to be due to inappropriately low hepcidin expression $[65,66,67]$. Several researchers showed that alcohol consumption decreases hepcidin levels mainly due to an inhibition of transcriptional factor known to regulate hepcidin expression $[65,66,67]$. Several studies suggest that iron overload contributes to progression of ALD likely due to the facts that both iron and alcohol leads to generation of Reactive oxygen species (ROS) and thereby to activation of hepatic stellate cells (HSC) with subsequent fibrogenesis $[68,69]$. In contrast to ALD, the iron accumulation in HCV infected patients starts approximately at the age of 40 years. Several groups reported that $\mathrm{HCV}$ - infected patients displaying hepatic iron overload developed a more severe liver damage $[33,64]$. Similar to ALD, iron accumulation in hepatocytes of HCV - infected patients is likely due to hepcidin suppression. Hepatic iron overload is thought to lead to generation of ROS as well as to mitochondrial damage [70]. 


\subsection{Iron redistribution and storage}

\subsubsection{Plasma iron and mechanism of cellular iron uptake}

To avoid toxic reactions, most of iron in the blood is bound to plasma proteins. Transferrin (TF) represents the major iron carrier, while minute iron amount is also bound to albumin or citric acid [71]. The major function of $\mathrm{TF}$ is to transport iron through the body. Transferrin is a glycoprotein with homologous $\mathrm{N}$ - and $\mathrm{C}$ - terminal iron binding domains and is synthesized mainly in the liver. Under normal conditions, about $30 \%$ of plasma TF is loaded with iron. To that end, TF - binding is also crucial for cellular iron uptake. The $\mathrm{TF}$ - iron complex binds to Transferrin Receptors 1 (TFR1) (Figure 1.2) [72,73] which is expressed on all dividing cells. In contrast to TFR1 transferrin receptor 2 (TFR2) [74] is expressed primarily in the liver and binds to $\mathrm{TF}$ - iron (Fe III) complex with much lower affinity [75]. The precise role of TFR2 is unknown, but it seems to be involved in iron sensing rather than iron uptake. Upon binding to TFR1, TF - bound iron (Fe III) is taken up by the cell via receptor mediated endocytosis (Figure 1.2) [76]. Within the endosome, the internalized iron is released from TF, a process which requires an ATP - dependent acidification of endosome as well as reduction of Fe III to Fe II [77,78]. The reduction of FeIII to FeII is mediated by ferrireductase STEAP3 [79]. The ferrous iron is then transported into the cytoplasm by Dvalent Metal Transporter 1 (DMT1) [80]. At acidic pH the apotransferrin (i. e. TF which lost its iron) remains bound to TFR1 and is brought back to the cell surface. After a switch to neutral $\mathrm{pH}$, apotransferrin separates from TFR1 and is releases into extracellular milieu where it can bind the next iron ion $[79,81]$.

Under normal conditions most of plasma iron is bound to TF, and only small fraction remains as NTBI [82]. In case of plasma iron overload, capacity of TF to bind iron is exceeded which leads to high level of NTBI $[82,83]$. Additionally, free iron is toxic since it produces reactive oxygen species and NTBI serve as an important marker of potentially toxic iron [82]. The precise composition of NTBI is unknown, but they include iron bound 
to albumin or small organic acids such as citric [78]. The uptake of NTBI is incompletely understood but seems to involve DMT1 [84,85] (Figure 1.2) and stimulator of iron transport (SFT) which is found on plasma membrane of hepatocytes. Accordingly, expression of DMT1 and SFT is increased in situation of iron overload $[84,85,86,87]$.
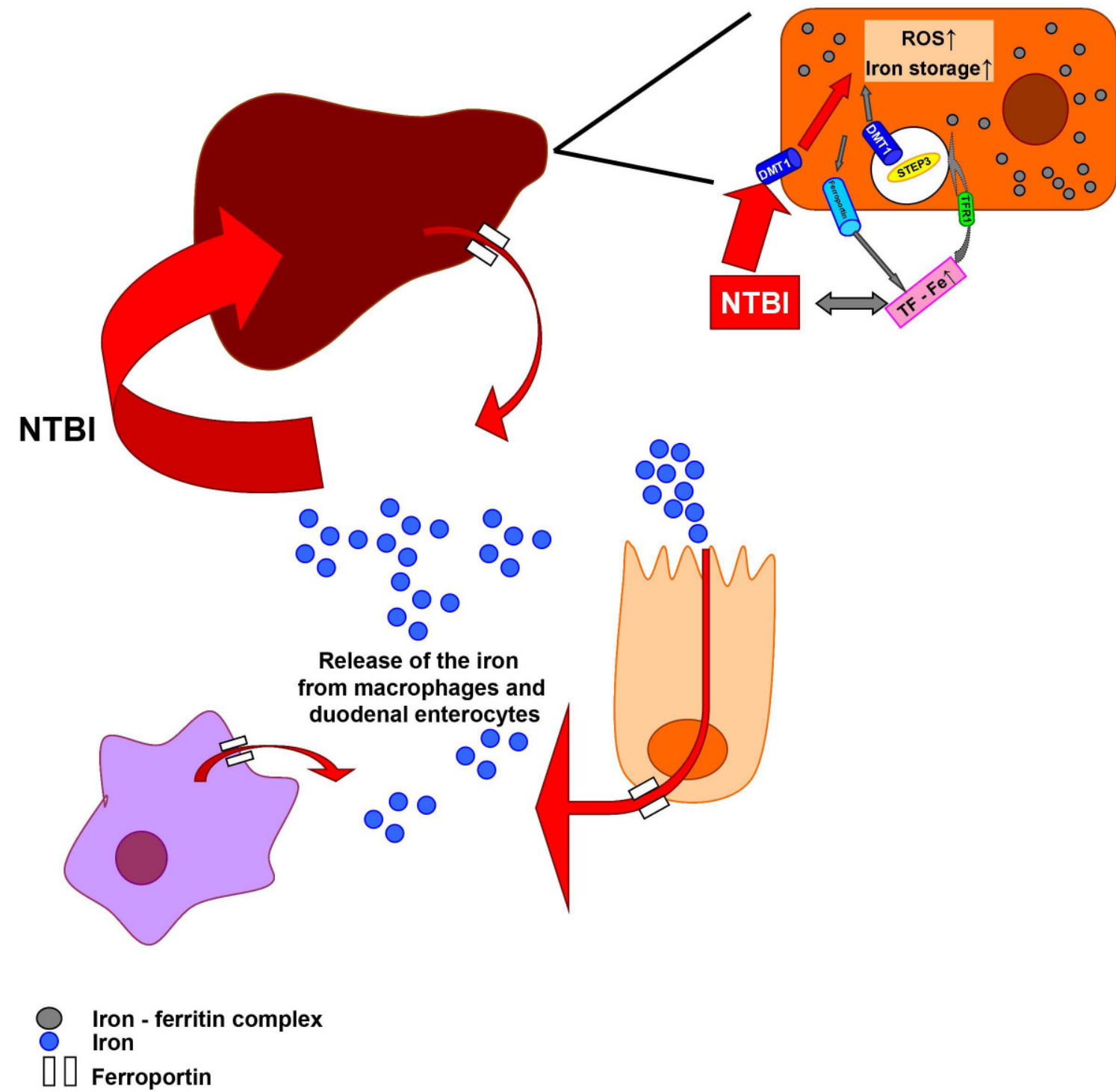

Figure 1.2. Pathogenic model of hepcidin deficient hemochromatosis. Loss of hepcidin signalling leads to development of hemochromatosis (for instance, Hemochromatosis Type 1, 2A and 2B) due to uncontrolled iron absorption by intestine. Elevated iron amount leads to increased amount of NTBI which are taken up and stored by liver hepatocytes. Heavy iron accumulation within the liver may lead to iron toxicity due to production of ROS and disruption of lysosomes. These processes may in term cause apoptosis or other forms of cellular death. 


\subsubsection{Storage of intracellular iron}

Intracellular iron has to be stored in nontoxic form to prevent formation of ROS, but at the same time has to be available for all cellular needs. The most abundant iron storage form constitutes the binding to ferritin (Figure 1.2) [88]. Ferritin is a ubiquitously expressed protein of $450 \mathrm{kDa}$ consisting of 24 subunits which are both of the light (L, $19 \mathrm{kDa})$ and heavy type $(\mathrm{H}, 21 \mathrm{kDa})$ [89]. Up to 4500 iron atoms bound to oxygen can be stored within ferritin, which forms a shell around the iron. Ferritin production is regulated by iron content and hepatic ferritin amount correlates with body iron levels [90]. Under normal conditions, hepatocytes are the major iron - storing and ferritin - synthesizing cells [88]. The majority of this protein is located within the cell, but a small part of ferritin is glycosylated and secreted into the circulation [88]. Of note, serum ferritin constitutes a useful parameter to estimate the body iron stores. The serum ferritin binds iron, but does not significantly affect iron trafficking throughout the body. Extracellular ferritin is quickly removed from the plasma by the liver via binding to a specific ferritin receptor and subsequent endocytosis [91]. Although the majority of the ferritin is taken up by hepatocytes, hepatic stellate cells (HSC) are also able to take up ferritin [88]. Mitochondrial ferritin represents another iron - sequestering protein localizing to mitochondria [92]. Overexpression of mitochondrial ferritin leads to iron sequestration within mitochondria, decrease in cytosolic ferritin and an increase in TFR1 expression [92]. Another important iron storage complex is hemosiderin (see Figure 1.2). Once the liver becomes iron overloaded, ferritin molecules are proteolytically degraded and form hemosiderin aggregates which are able to store even more iron [89]. Iron is also found in iron - sulfur (Fe-S) proteins [2]. This general term describes a family of metalloproteins such as ferredoxins, NADH dehydrogenases, cytochrome c reductase, and nitrogenase, which all contain $\mathrm{Fe}-\mathrm{S}$ clusters in their structure. Fe-S proteins are found in cytoplasm, mitochondria, endoplasmatic reticulum (ER) and nucleus and assist in many important 
cellular functions such as catalysis, electron transport, DNA/RNA synthesis and repair, and iron as well as haem metabolism [2,3].

\subsection{Iron toxicity via reactive oxygen species (ROS). Mechanism of oxidative liver fibrosis development}

Liver iron is usually stored in the form of ferritin within lysosomes and the cytoplasm as well as in the form of mitochondrial ferritin within mitochondria. In situation of iron overload, lysosomal iron is also stored in the form of hemosiderin $[93,94,95,96]$. Such an lysosomal iron accumulation is found in hemochromatosis patients [97] and these lysosomes are proins to generation of free iron which leads to oxidative stress and may result in apoptosis $[96,98]$. Free iron is an established transition metal which catalyses the formation of the highly reactive hydroxyl radicals $(* \mathrm{OH})$ via Fenton and Haber - Weiss reactions $[99,100]$.

$\mathrm{H}_{2} \mathrm{O}_{2}+\mathrm{O}_{2}{ }^{*-} \stackrel{\mathrm{Fe}}{\rightarrow} \mathrm{OH}^{-}+\mathrm{OH}^{*}+\mathrm{O}_{2} \quad$ Fenton and Haber - Weiss reaction

This is why cellular organelles produce ROS as a consequence of unbalanced iron overload. To prevent cellular damage, the ROS have to be detoxified with enzymes such as superoxide dismutase, catalase, and glutathione peroxidases [96,101]. In this protective response, an overwhelming ROS lead to oxidative damage of cellular organelles and membranes causing a leakage of enzymes. It also results in oxidation of amino acids and in DNA strand breaks [70,100]. In particular, hydrogen peroxide in combination with lysosomal free iron leads to lysosomal membrane damage $[95,102]$. At the same time, iron overload results in mitochondrial dysfunction and inhibition of mitochondrial electron transport chain via peroxidation of cytochrome $\mathrm{C}$ oxidase and increase in mitochondrial DNA damage [102]. $\mathrm{OH}^{*}$ groups react with polyunsaturated fatty acids and that leads to generation of lipid radicals as well as formation of peroxyl radicals in the presence of oxygen (Figure 1.3). 


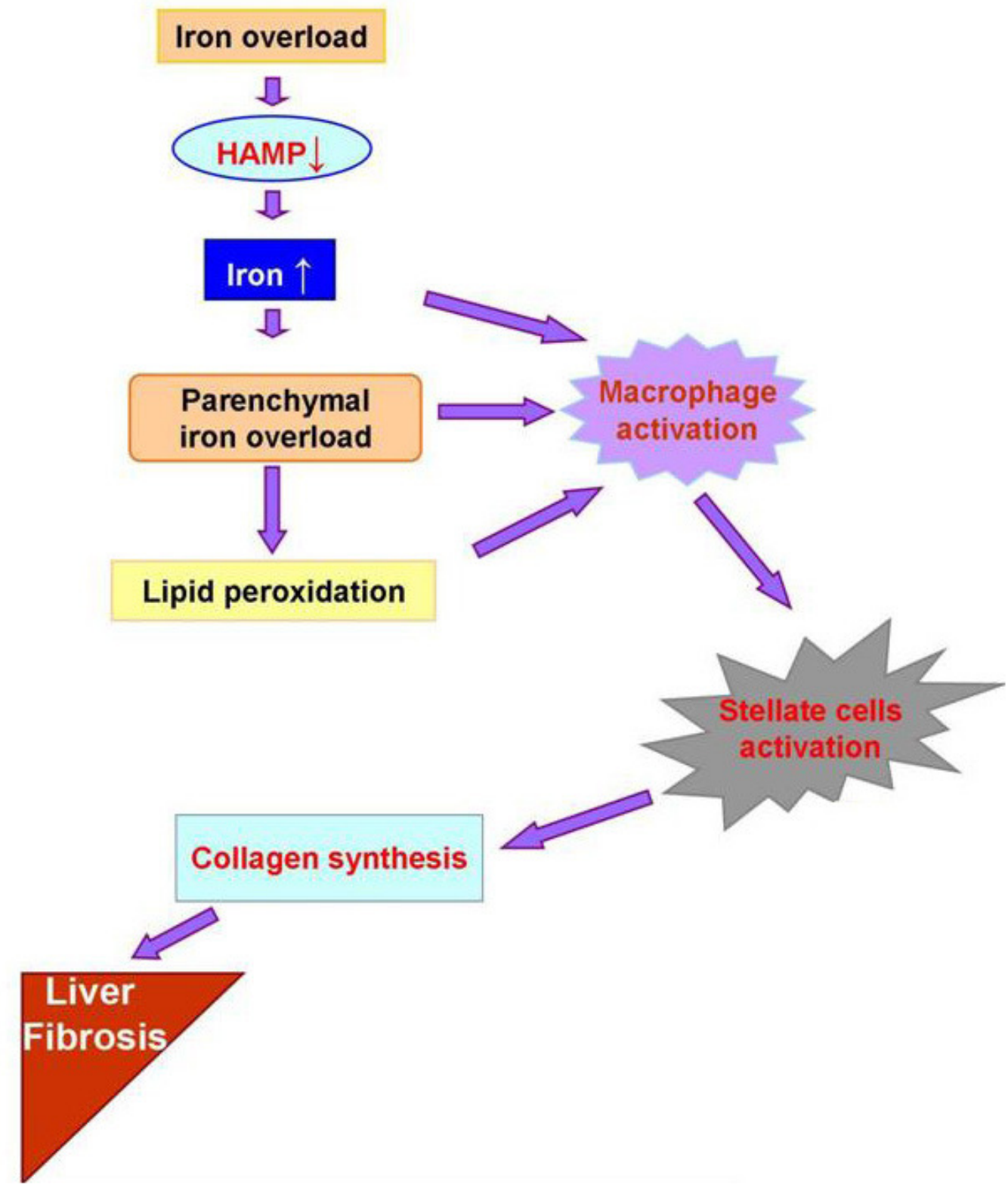

Figure 1.3. Potential mechanism of iron associated liver damage. Inappropriately low concentration of hepcidin leads to iron overload. The liver is the major iron storage organ and hepatocytes are able to store large quantities of iron in a chemically inert form. When this storage capacity is exceeded, unbound iron leads to ROS generation, lipid peroxidation, and subsequent activation of macrophages (both resident termed as Kupffer cells and monocytes recruited from blood stream). Macrophages in term stimulate activation of stellate cells via generation of proinflammatory cytokines. The active stellate cells start to produce collagen and thereby lead to development of liver fibrosis. 
The iron induced ROS initiate a cascade of reactions with lipids which leads to generation of end - products such as Malondialdehyde (MDA) or 4-hydroxynonenal (HNE). The presence of MDA in tissues can be detected due to their reactivity with thiobarbituric acid (TBA) which results in formation of fluorescent product [102,103]. Moreover, end products of lipid peroxidation may react with DNA thereby forming DNA adducts. Last but not least, protein carbonylation, oxidation of amino acids in proteins, inactivation of specific enzymes via oxidation of co - factors. The presence of oxidative stress does not only cause cellular damage, but also leads to inflammation with recruitment of resident macrophages (Kupffer cells) and blood stream macrophages (mononuclear cells) [93,104]. Activated macrophages produce various signalling molecules such as adhision molecules (intracellular adhesion molecule - ICAM), growth factors (hepatocytes growth factor HGF), profibrogenetic stimuli (connective tissue growth factor - CTGF, platelet derived growth factor - PDGF), cytokines and chemokines (monocyte chemoattractant protein MCP - 1, transforming growth factor beta TGFß) $[105,106,107]$. The messenger molecules induce activation of HSC which start producing expression of extracellular matrix (ECM) proteins such as collagen type I/III and fibronectin [108] and thereby lead to development of liver fibrosis [103]. 


\section{Aims of the study}

While there is a large body of evidence demonstrating that iron overload precipitates the development of human liver diseases, the underlying pathomechanisms remain incompletely understood. This is in particular due to the fact that there is a lack of animal models leading to development of liver damage as a consequence of chronic iron overload. To overcome this problem, was explored the usefulness of hepcidin knockout animals fed with iron-rich diet as such a model.

Hepcidin knockout mice were chosen given that (i) hepcidin represents the key regulator of iron homeostasis; (ii) hepcidin expression is inappropriately low in multiple human conditions and (iii) mutations in hepcidin lead to particularly severe disease.

By employing this model, there is a hope to gain further insight into the following basic questions of iron biology:

- Is the lack of hepcidin in combination with iron-rich diet sufficient to precipitate the development of liver injury?

- How is the iron storage and trafficking in the liver altered in situations of chronic iron overload?

- What are the precise mechanisms of iron-overload induced tissue damage? 


\section{Material and methods}

\subsection{Animal experiments}

To study the consequences of multivisceral iron overload, were used previously described hepcidin knockout (KO) mice on C57BL/6N background [54]. Genotyping was performed as previously described [109] with primers given in Table 2.1. To induce iron overload, hepcidin $\mathrm{KO}$ mice and their non-transgenic littermates were fed $3 \%$ carbonyl iron containing diet (Ssniff, D12450B including $3 \%$ Iron carbonate, Sigma) starting at the age of 28 days. The diet was pre-mixed and ordered as pellets (Sniff). Mice fed standard diet (Ssniff, D12450B) were used as controls. Mice were sacrificed at indicated time-points by $\mathrm{CO}_{2}$-inhalation, blood was obtained by cardiac puncture for measurement of serum parameters and liver was rapidly removed and cut into pieces that were: 1) immediately fixed in $10 \%$ formalin for histological/immunohistochemical (IHC) analysis, 2) snapfrozen in liquid nitrogen for protein analysis, or 3) submerged into RNAlater stabilization reagent (Ambion) for mRNA analyses. The animal experiments were approved by the state of Baden-Württemberg in Germany and the University of Ulm animal care committee and were conducted in compliance with the German Law for Welfare of Laboratory Animals.

\subsection{Deoxyribonucleic acid (DNA) isolation}

DNA was isolated from mouse tail tips and genotyping has been performed using the DNeasy Blood and Tissue kit (Qiagen). Briefly, the tail tips were digested in a mixture of proteinase $\mathrm{K}$ and buffer ATL at $56^{\circ} \mathrm{C}$ over night. To ensure an optimal binding of DNA to the column, $200 \mu \mathrm{l}$ buffer AL and then $200 \mu 196$ - $100 \%$ ethanol (Sigma) were added, samples were thoroughly vortexed after each step and placed onto DNeasy Mini spin columns. During subsequent centrifugation, DNA selectively bound to the column and the flow-through was discarded. To wash the column, $500 \mu \mathrm{l}$ of AW1 buffer and then $500 \mu 1$ of AW2 was used, each step followed by a centrifugation. To remove the washing buffer 
AW2 completely, the collection tube was replaced with fresh one after first centrifugation and columns were centrifuged once more at $20000 \mathrm{~g}$ for 1 minute. To elute DNA from this column, a low - salt elution buffer AE (provided in the kit) with basic $\mathrm{pH}$ was used.

\subsection{Mouse genotyping}

Hepcidin $\mathrm{KO}$ and their non-transgenic littermates were genotyped using polymerase chain reaction (PCR). To that end, were used previously described primers [54]- see table 2.1 for details. PCR reaction was carried out with the GoTaq Green Master Mix (Promega) which includes Taq DNA Polymerase, dNTPs, and the appropriate reaction buffers.

Reaction mix:

GoTaq Green Master Mix, 2x $\quad 25 \mu 1$

Primer, each $10 \mu \mathrm{M}$

DNA template $\quad 2.5 \mu 1$

Nuclease-free water $\quad 16.5 \mu 1$

The reaction mix was placed into PCR tubes and the reaction was started with an initial denaturation of DNA at $94^{\circ} \mathrm{C}$ for 4 minutes. After that, 40 PCR cycles were performed, such consisting of (i) a denaturation step at $94^{\circ} \mathrm{C}$ for 30 seconds; (ii) an annealing step at $54^{\circ} \mathrm{C}$ (optimal primer melting temperature) for 30 seconds, these step enabled this primers to bind to single strand DNA; (iii) extention step performed at $72^{\circ} \mathrm{C}$ (optimal working temperature for Taq DNA Polymerase) for 30 seconds (extension time is dependent on DNA length and Polymerase, under normal conditions this time is about 10 second per 100bp of DNA). To ensure that all single strands of the DNA fully extended, the final extension was performed at $72^{\circ} \mathrm{C}$ for 10 minutes and the DNA fragments were stored at $4^{\circ} \mathrm{C}$. 


\subsection{Agarose gel electrophoresis}

To estimate the size of DNA products, agarose gel electrophoresis was performed. This method allows separating the molecules based on their size. To that end, negatively charged DNA molecules move through agarose matrix due to an applied electric field. Shorter molecules move faster than longer and migrate further. After PCR amplification, $9 \mu 1$ of the sample was mixed with $1 \mu \mathrm{l}$ of $6 \mathrm{x}$ DNA Loading Dye (Fermentas) and loaded on $1.5 \%$ agarose gel (Biozym; this gel concentration was used to allow detection of this expected relatively small DNA fragments). For detection of DNA fragments, $0.0005 \%$ ethidium bromide (Sigma) was added. This dye intercalates between two DNA strands and omits fluorescence under UV light. Electrophoresis was performed in TAE buffer at $130 \mathrm{~V}$ for 45 minutes. Gene Ruler 50 bp (Fermentas) was used to identify the DNA fragment size.

\subsection{Western Blot}

All procedures concerning protein isolation and latter application were performed on ice. To avoid the protein degradation, livers were homogenized in $3 \%$ sodium dodecyl sulphate (SDS) homogenisation buffer (buffer described below). After homogenisation, the tissue lysates were centrifuged (14000 rpm, 1 minute) to remove non - solubilized debris. To ensure that samples reach sufficient density to sink to the bottom of the well, liver tissue homogenates were diluted $1: 2$ with 4 x loading buffer which contains glycerol. Protein concentration was determined using the Bio - Rad DC protein assay (Bio - Rad Laboratories). This colorimetric method is based on binding of the dye Coomassie Briliant Blue $\mathrm{G}-250$ to basic and aromatic amino acid residues which results in a shift in absorbance maximum from 465 to $595 \mathrm{~nm}$. Equal amounts of protein were separated by $10 \%$ SDS-polyacrylamide gel electrophoresis (PAGE, see figure 2.1). Briefly, denaturated proteins bind to SDS to ensure relatively constant negative charge and are therefore separated based on their molecular weight. The gels consisted of stacking gel which has large pores and enable concentration of proteins in a thin zones and a resolving gels $(10 \%$ 
gel was used in most gels), which leads to a separation of proteins based on their size. The electrophoresis was performed at $70 \mathrm{~V}$ for 30 minutes (migration thorough stacking gel) and after that at $110 \mathrm{~V}$ for 1 hour (migration through resolving gel) using Bio - Rad system. After the electrophoretical separation, the negatively charged proteins were transferred onto PVDF membrane $(0.45 \mu \mathrm{m}$ pore size, Millipore $)$ using constant current of 0.2 A for 80 minutes and a wet - blot apparatus (Bio - Rad). To reduce nonspecific binding to the membrane, PVDF membranes were blocked 1 hour at room temperature with $5 \%$ Milk powder (Roth) dissolved in Tris Buffered Saline containing 0.1\% Tween (TBST) buffer. To detect the proteins of interest, the membranes were incubated with primary antibody (diluted in blocking buffer) at $+4^{\circ} \mathrm{C}$ overnight. Afterwards, at least 5 washing steps (5 minutes each) with TBST buffer were performed to remove the unbound antibody before the membranes were incubated with secondary antibody (diluted in $5 \%$ blocking buffer) for 1 hour at room temperature. After 5 TBST washes, these membranes were incubated with enhanced chemiluminescence reagent (GE Healthcare/Amersham Biosciences). This reagent containing substrate for horse radish peroxides (HRP) and the enzyme coupled to secondary antibodies. The reaction between HRP and this substrate leads to formation of hydrogen peroxide which oxidizes luminal and therefore leads to an emission of light. The antibodies (Abs) used were anti Hsp 60 (heat shock protein 60, Stressgen), cathepsin B (Santa Cruz), cytochrome C (Santa Cruz), FTH1 (ferritin heavy polypeptide 1, Cell Signaling), 3 - tubulin (Sigma), HDAC2 (histone deacetilase 2, Cell Signaling), D237 (obtained from MB Omary, University of Michigan) [110], LC 3 (light chain 3, Novus Biological), p62 (Progen), and Hsc70 (constitutively expressed chaperone protein 70, Stressgen). 


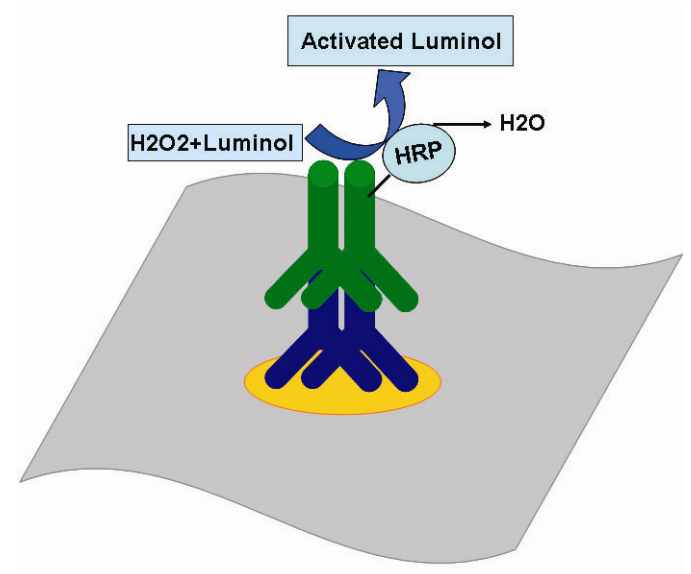

Figure 2.1. Schematic of protein detection by Western blotting. Using SDS - gel electrophoresis, proteins were separated based on their molecular weight. After that, proteins were transferred onto PVDF membrane (gray) and detected by a combination of protein specific primary (blue) and species - specific secondary (green) antibody. The secondary antibody was conjugated to an enzyme named horseradish - peroxidase (HRP). After addition of the substrates, HRP catalyzed the production of $\mathrm{H}_{2} \mathrm{O}_{2}$ which leads to luminal oxidation and subsequent light emission.

\subsection{Subcellular fractionation}

To better understand where the iron accumulated inside of the cell, subcellular fractionation was performed. This method allows separating nucleus, mitochondria, lysosomes, autophogosomes, and cytoplasm. Subcellular fractionation was performed as it was described previously by Wattiaux et al [111]. Briefly, the livers were harvested and washed twice with cool $\left(4^{\circ} \mathrm{C}\right)$ phosphate buffered saline (PBS Dulbecco, Biochrom) to remove red blood cells. The livers were homogenized in $0.25 \mathrm{M}$ sucrose (Sigma) using a teflon homogenizer (Mikro-Tissue homogenizer) with a ratio between buffer volume and liver weight of $7: 1$. To remove cell debris, the mixture was filtered through two layers of cheesecloth. The flow-trough was collected in tube and centrifuged at $4{ }^{\circ} \mathrm{C}, 2000 \mathrm{~g}$ for 5 minutes, and then supernatant was collected in separate tube and kept on ice as supernatant 1. To clear the nucleus fraction from the other fractions, pellet 1 was resuspended in $1 / 2$ volume of $0.25 \mathrm{M}$ sucrose (Sigma) and centrifuged at $4^{\circ} \mathrm{C}, 2000 \mathrm{~g}, 5$ minutes leading to a separation into supernatant 2 and pellet 2 . Both supernatants were put 
together for latter fractionation and pellet 2 was saved as nuclear fraction. To precipitate further cellular organelles, the supernatant was centrifuged at $17000 \mathrm{~g}$ for 12 minutes at $4^{\circ} \mathrm{C}$, after which the supernatant was saved as cytoplasm and the pellet 3 was used for isolation of the remaining cellular organelles. For this purpose, a Nycodenz gradient centrifugation was used (Figure 2.2), which allows separating cellular parts according to their size and weight (smaller cellular parts are found in lower density and bigger cellular parts in higher density fraction). To do so, the pellet 3 was mixed with $1.9 \mathrm{ml}$ of sucrose and $2.8 \mathrm{ml}$ of $85.6 \%$ nycodenz (Progen) in water $(\mathrm{pH}=7.2)$ and (see Figure 2.2) transferred to the bottom of an ultracentrifugation tube (Beckmann Coulter). The nycodenz gradient was prepared 2 hours in advance and stored at $4^{\circ} \mathrm{C}$. The gradient centrifugation was performed on ultracentrifuge with SW41 rotor for 3 hours at $25000 \mathrm{rpm} 4{ }^{\circ} \mathrm{C}$. Afterwards, the different layers were carefully collected.

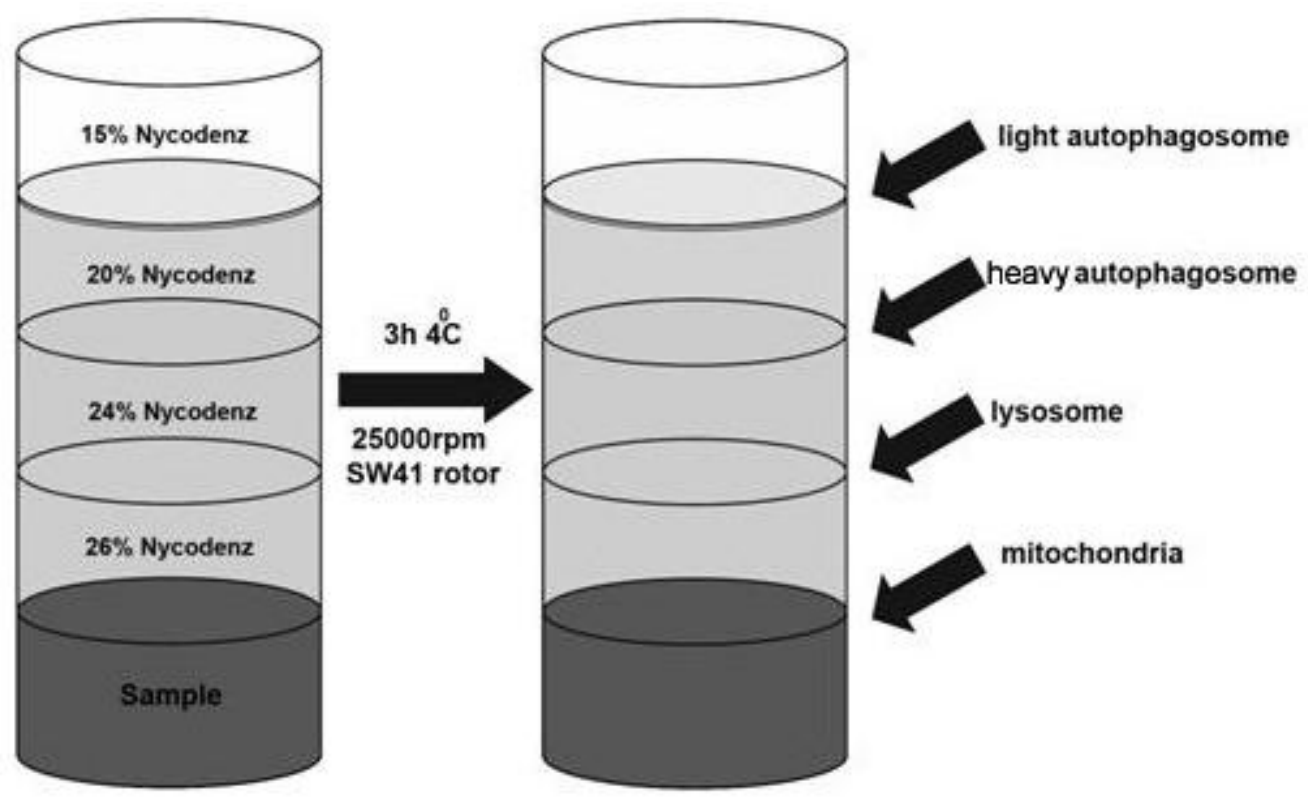

Figure 2.2. Schematic view of subcellular fractionation method based on Nycodenz density gradient. This method allows separation of organelles based on their size. For instance, smaller and lighter particles and found in the lower density layer and vice versa. 


\subsection{Hydroxyproline assay}

To detect collagen amount in liver tissue samples hydroxyproline assay was performed. Hydroxyproline is an amino acid modification found almost exclusively in collagen and plays a key role in collagen stability. Hydroxyproline in liver samples was measured colorimetrically as described [112]. Briefly, liver tissues samples were weighted and homogenized in water. The lysates were hydrolysed in $6 \mathrm{~N} \mathrm{HCL}$ at $110^{\circ} \mathrm{C}$ for 18 hours, then filtered to remove debris and evaporated by speed vacuum centrifugation. The pellets or $0.5-20 \mu \mathrm{g}$ of trans-4-hydroxy-L-proline standards (Sigma) were dissolved in $50 \mu \mathrm{l}$ of distilled water. The oxidation of the samples was performed via addition of $450 \mu 1$ of $56 \mathrm{mM}$ chloramine $-\mathrm{T}$ trihydrate $($ Sigma) in acetate buffer $(\mathrm{pH}=6.5)$ and incubation for 25 minutes at RT. The detection of hydroxyproline is based on formation of the pyrrole type chromophore with absorbance at wave length of $562 \mathrm{~nm}$. To form the compound, $500 \mu \mathrm{l}$ of Ehrlich solution was added and this mixture was incubated at $65^{\circ} \mathrm{C}$ for 20 minutes. After incubation, the samples were measured at $562 \mathrm{~nm}$. The results are presented as means \pm standard deviation (SD).

\subsection{Serum enzymes concentrations and serum iron parameters}

The serum levels of alanine aminotransferase (ALT), aspartate aminotransferase (AST), alkaline phosphatase (AP), serum ferritin, and serum iron were analyzed in the local clinical chemistry department. Data are shown as means \pm SD.

\subsection{Tissue staining}

The harvested livers were fixed in $10 \%$ buffered formalin at RT overnight, embedded in paraffin, sectioned $(3 \mu \mathrm{m})$, and stained with Haematoxylin and Eosin (H\&E), Perls' Prussian Blue as well as Sirius Red staining or were used for immunohistochemistry (IHC). 


\subsection{Perls' Prussian Blue staining}

Formaldehyde fixed liver tissue sections were washed twice with xylol (VWR Prolabo) 10 min each time to remove paraffin and then hydrated with a descending ethanol series (100\%; $96 \% ; 90 \% ; 80 \%$ and $70 \%$ - 2 minutes each). Afterwards, the slides were washed with deionized water 3 times for 5 minutes each. To produce blue iron complex liver slides were incubated 30 minutes in a mixture of $2 \mathrm{~g}$ of potassium hexacyanoferrate(II) trihydrate (Sigma) dissolved in distilled water and then mixed with $2.7 \% \mathrm{HCL}$ in water for $\mathrm{pH}$ adjustment. As a next step, the slides were washed in deionized water and stained at RT for 5 minutes with $0.5 \%$ Eosin G-solution (Merk) for visualisation of basic parts of the cell (for instance cytoplasm). After that, slides were washed with deionised water, dehydrated in a graded ethanol series $(70 \% ; 80 \% ; 90 \% ; 96 \%$ and $100 \%$ each $1 \mathrm{~min}$ ) and incubated in xylol for 10 minutes. The slides were covered with glass coverslip using the Entellan medium (Merk).

\subsection{Picro-Sirius-Red (PSR) staining}

Picro-Sirius-Red (PSR) staining was used for visualization of the fibrotic matrix. Paraffin fixed liver tissues were deparaffinized with xylol and then hydrated with different concentrations of ethanol (100\%; $96 \% ; 90 \% ; 80 \%$ and $70 \%)$. Tissue was incubated in water for $5 \mathrm{~min}$ and placed into iron haematoxylin solution (Merk) for 10 minutes for visualisation of nuclei. After that, the slides were washed with tap water. A mixture of $500 \mathrm{ml}$ Picric acid solution $1.2 \%$ (Chroma) and $0.5 \mathrm{~g}$ of Direct Red 80 (Sigma) was used to stain the fibrotic areas. The staining was performed for 1 hour at RT and samples were washed in deionized water afterwards. Subsequently, the probes were dehydrated via an ascending ethanol series and covered with glass coverslip. Fibrosis score of the livers was evaluated using an established Scheuer scoring system [113]. 


\subsection{Haematoxylin and Eosin staining (H\&E)}

For overall histological assessment, H\&E staining was used. The tissue was deparaffinized in xylol and hydrated with serial dilutions of ethanol (100\%; $96 \% ; 90 \% ; 80 \%$ and $70 \%)$. After that, probes were incubated in deionised water for 1 minute at RT. To visualise the nuclei, slides were incubated with haematoxylin solution (Dako) for 5 minutes. After removing the stain via washing with tap water for 5 minutes, samples were placed into $0.5 \%$ Eosin G-solution (see above) for 5 minutes (cytoplasm staining) and were washed with deionised water afterwards. Stained slides were dehydrated with serial dilutions of ethanol and xylol and covered with glass coverslip using Entellan medium (see above).

\subsection{Immunohistochemical staining}

Immunohistochemistry staining was performed with a mouse ABC Staining System (Vectastain ABC Kit, Vector Laboratories) as described previously [114]. To that end, deparrafinized, hydrated sections were boiled in Antigen Retrieval Solution (Vector Laboratories) and preincubated with $3 \%$ hydrogen peroxide solution $\left(\mathrm{H}_{2} \mathrm{O}_{2}\right)$ (Fischer) for 10 minutes to remove endogenous peroxidase activity. To reduce unspecific background staining, slides were incubated with a blocking buffer containing bovine serum albumin (BSA, fraction V) (Serva). After exposure to BSA-containing buffer for 20 minutes, the slides were incubated with primary antibody D237 for 1 hour, washed 3 times with TBST, and incubated with biotinylated secondary antibody for 30 minutes (all at RT). For detection of the specific signal, a chromogenic reporter - $A B$ enzyme reagent (Vector Laboratories) was used. To that end, the slides were incubated with $\mathrm{AB}$ enzymes reagent for 30 minutes and washed with TBST. This enzyme reacts with a substrate Vector Nova Red (Vector Laboratories, INC) to yield an intensively colour product that can be analyzed with a microscope. The slides were than dehydrated with graded ethanol series $(70 \% ; 80$ $\%$; $90 \% ; 96 \%$ and $100 \%$ each 1 minute) and incubated with xylol for 10 minutes. The slides were covered with glass coverslip using the Entellan medium (Merk). 


\subsection{DNA damage staining}

DNA damage staining was performed with "In situ Cell Death Detection Kit, POD” from Roche (TdT - mediated dUTP Nick End Labeling). Oxidative damage is known to cause single strand breaks and fragmentation of DNA. The terminal deoxynucleotidyl transferase (TdT) detects these nick ends and ligates fluorescein labelled nucleotides to the free 3'- $\mathrm{OH}$ - ends of the DNA fragments. The fluorescein - nucleotide adducts are then recognized by an HRP - conjugated antibody and after addition of substrate visualised in light microscopy.

The staining was performed on paraffin embedded liver sections. Sections were deparaffinized in xylol and hydrated with serial dilutions of ethanol (100\%; $96 \%$; $90 \%$; $80 \%$ and $70 \%$ ). Then, probes were incubated in deionised water for 1 minute at RT. After that, sections were washed in PBS for 30 minutes and put for 10 minutes into blocking solution containing $3 \%$ hydrogen peroxide in methanol to inhibit the endogen peroxide. Subsequently, probes were shortly washed with PBS, incubated 2 minutes on ice with permeabilisation solution $(0.1 \%$ Triton $X-100 / 0.2 \%$ sodium citrate) and another washing step with PBS was performed. One slide was used as a negative control and labelled with $50 \mu 1$ of Label solution (supplemented in kit), the other slides were treated with mixture of $45 \mu \mathrm{l} \mathrm{Label} \mathrm{solution}$ and $5 \mu$ Enzyme solution (the enzyme terminal deoxynucleotidyl transferase ( $\mathrm{TdT}$ ) catalyzes the template - independent polymerization of deoxyribonucleotides to the 3"- end of single and double strand DNA) and incubated at $37^{\circ} \mathrm{C}$ in a dark, humidified chamber for 1 hour. Slides were washed with PBS 3 times and then were incubated with $50 \mu \mathrm{l}$ of Converter - POD (peroxidase) for 30 minutes at $37^{\circ} \mathrm{C}$ in a humidified chamber. After washing with PBS, tissue slides were treated with DAB solution as a POD substrate for several minutes, until the brown colour was detected under light microscope, washed with PBS and then rinsed shortly with $70 \%$ ethanol to reduce 
DAB (diaminobenzidine) staining. After that, slides were washed one more time with tap water and were covered with medium and coverslip.

\subsection{Electron microscopy staining (EM)}

EM was prepared using standard procedure described previously by Walther et al 2003 for visualisation of the cellular organelles and iron distribution in the cell [115]. Liver tissues with thickness of approximately $0.2-0.4 \mathrm{~mm}$ were placed in the cavity of supporting aluminium plate and surrounded by 1 - hexadecane upon application of a second covering plate. The prepared sample - sandwiches were immediately high pressure (> 2000 bar) frozen in liquid nitrogen using Balzers HPM 010 apparatus with in which they were stored until next step. To bring the samples to RT and make a chemical stabilisation of tissue a few soft rising temperature steps were performed: the samples were replaced for 12 hours into $-90^{\circ} \mathrm{C}$ with water - free acetone mixture (Acetone, $2 \%$ of Osmiumtetroxid, $1 \%$ of Uranylacetate and $1 \%$ of Methanol and $5 \%$ of water), then $-60^{\circ} \mathrm{C}$ for 6 hours and $30^{\circ} \mathrm{C}$ for 3 hours. After that, samples were brought to RT and infiltrated with epoxy resin (Epon). This preserves the tissue sample in a snapshot of its solution state. The image was created on FEI 300 kV "Titan" Raster-Transmissions Electron microscope using a beam of electrons.

\subsection{Determination of nonheme hepatic iron}

Hepatic iron content was measured as described previously [116]. Firstly, liver tissue were dried at $120^{\circ} \mathrm{C}$ for 24 hours and weighted. Subsequently, they were hydrolysed in $1 \mathrm{ml}$ of $100 \mathrm{mM}$ citric acid (Calbiochem) at $60^{\circ} \mathrm{C}$ for 4 hours. To detect total iron, $500 \mu 1$ of the samples were mixed well with $500 \mu \mathrm{l}$ of $100 \mathrm{mM}$ citric acid, $50 \mu 1$ of L-ascorbic acid (Sigma) which can reduce the iron (III) to iron (II) and then iron (II) react with $100 \mu$ of $5 \mathrm{mM}$ Bathophenanthrolinedisulfonic acid disodium salt (BPS, Sigma) which forms red colour complex with iron. The samples were mixed well and incubated for 30 minutes in the dark to develop the described red - compound iron - complex. The absorbance was 
measured with a spectrophotometer at wavelength $535 \mathrm{~nm}$. The data are presented as average \pm SD

\subsection{Determination of Non Transferrin Bound Iron (NTBI)}

To detect free iron NTBI measurement was performed. Determination of NTBI was done as described [117]. This method consist two steps: first - to produce the FeNTA (iron nitrilotriacetic acid) complex with NTBI and second - to detect the red iron complex with Bathophenanthrolinedisulfonic acid disodium salt hydrate (BPT) as described above. For formation of FeNTA complex, liver tissues were homogenized in water and mixed with $800 \mathrm{mM}$ NTA (mixture of nitrilotriacetic acid disodium salt (Sigma) and trisodium salt (Sigma), $\mathrm{pH}=7$ ) in ratio 1:9. To clear the FeNTA from cellular debris and protein mixture, the samples were ultrafiltered using Amicon Ultra 0.5 Centrifugal Filter Unit with Ultracel - 30 membrane (Millipore) with centrifugal force of $3000 \mathrm{~g}$ for 1 hour at $4^{\circ} \mathrm{C}$. The filtrates were mixed in ratio $1: 1$ with $5 \mathrm{mM}$ MOPS (Sigma) buffer $(\mathrm{pH}=7.4)$. For red complex formation, $50 \mu \mathrm{l}$ of $120 \mathrm{mM}$ sodium thioglycolate (TGA) (Sigma) in deionised water and $50 \mu \mathrm{l}$ of $60 \mathrm{mM}$ BPT (Sigma) in deionized water were added into solution and incubated for 30 minutes at room temperature. The complex was measured by spectrophotometer at $535 \mathrm{~nm}$. The data were presented as average $\pm \mathrm{SD}$.

\subsection{Ribonucleic acid (RNA) isolation}

To ensure optimal RNA quality, tissue samples were stored in RNAlater stabilization reagent (Ambion) and the RNA was isolated with a RNeasy mini kit (Qiagen). To that end, $\sim 20 \mathrm{mg}$ of liver was homogenized in lysis buffer containing: $600 \mu \mathrm{l}$ of RLT $+1 \%$ B mercaptoethanol (Sigma). To remove cell debris, the lysate was filtered thought QIAshredder columns (Qiagen) at $14000 \mathrm{rpm}$ for 3 minutes. The liquid was collected and mixed with $600 \mu \mathrm{l}$ of $70 \%$ ethanol to guarantee appropriate binding of RNA to the column. The complex was transferred onto RNeasy spin columns which bound RNA to their silica-based membrane. After discarding the flow-trough, columns were washed with 
buffer RW1. To remove DNA contaminations, columns were incubated with a mixture of RDD buffer - DNase (RNase - Free DNase Set) in ratio $70 \mu 1: 10 \mu l$ for 15 minutes at RT. After that, column was washed once with $350 \mu \mathrm{l}$ of RW1 buffer and twice with $500 \mu 1$ RPE buffer. To remove the RPE buffer completely, the column was placed onto a new collection tube after the last washing step and centrifuged once more at $14000 \mathrm{rpm}$ for 1 minute. At the end, RNA was eluated with $30 \mu \mathrm{l}$ of RNase free water provided in the kit. To increase RNA yield, the elution step was performed twice. The concentration of RNA was determined by measuring the absorbance at $260 \mathrm{~nm}$ in NanoDrop 1000 spectrophotometer (Thermo Scientific). The purity of RNA was calculated as an absorbance ratio of 260 and $280 \mathrm{~nm}$.

\subsection{Reverse transcription}

Each $2 \mu \mathrm{g}$ of isolated RNA was reverse transcribed using SuperScript II reverse transcriptase (Invitrogen). To that end, RNA was first mixed with $100 \mathrm{ng}$ of random primers (Invitrogen), $0.5 \mathrm{mM}$ of deoxynucleoside triphosphate (dNTP's) (5Prime) and DEPC treated water (Pyrogen free, Invitrogen) was added up to $13 \mu 1$ of total volume. The mixture was incubated at $65^{\circ} \mathrm{C}$ for 5 minutes for denaturation of secondary RNA structure and quickly placed on ice to let the primers anneal to the RNA. Then, $2 \mu 1$ of $0.1 \mathrm{M}$ DTT (Sigma), $4 \mu \mathrm{l}$ of $5 \mathrm{x}$ First - Strand buffer (provided in kit) and 200 units of reverse transcriptase-SuperScript were added. The transcription was performed at $42^{\circ} \mathrm{C}$ for 50 minutes. Finally, to stop the reaction, the samples were heated to $70^{\circ} \mathrm{C}$ for 15 minutes.

\subsection{Quantitative real - time PCR (RT - PCR)}

Quantitative real - time PCR was performed with a Sequence Detection System (Applied Biosystems 7500 fast Real Time PCR system) using specific primers (Table 2.1) and DNA binding dye SYBR Green which binds to all double strand DNAs in PCR and emits fluorescent light. An increase of the DNA products during PCR leads to increase in intensity of fluorescence which is measured during each cycle of PCR and allows 
quantification of the initial, target-gene specific, mRNA level. SYBR Green qPCR Master mix (Qiagen) which contains SYBR Green Dye, AmpliTag Gold Polymerase, and dNTPs with dUTP, was used for amplification and detection. The samples were pipetted into MicroAmp Fast Optical 96well Reaction Plate (Applied Biosystems) and were analyzed in duplicates. At least 4 individual mice were tested for each genotype. The mixtures were composed of $12.5 \mu \mathrm{l}$ of SYBR Green Master Mix, $1 \mu \mathrm{l}$ of $10 \mathrm{pM}$ forward and reverse primers, $9 \mu \mathrm{l}$ of DEPC treated water (Pyrogen free, Invitrogen) and $2.5 \mu 1$ of cDNA (complementary deoxyribonucleic acid). The plate was sealed with MicroAmp Optical Adhesive Film (Applied Biosystems) to prevent evaporation of the samples. Samples were collected to the bottom of the plate via a centrifugation at $2000 \mathrm{~g}$ for 3 minutes and amplification of the product was done using following conditions: initial activation of the enzyme at $95^{\circ} \mathrm{C}$ for 10 minutes; 45 amplification cycles each consisting of a denaturation step $\left(95^{\circ} \mathrm{C}\right.$ for 15 seconds) and an combination of annealing and extention step $\left(60^{\circ} \mathrm{C}\right.$ for 1 minute). L7 ribosomal protein (Table 2.1) was used as an internal control and cDNA levels were normalized so that L7 expression was equal in all tested mice. Data were analysed using Excel and Statistics programs. After confirming that the amplification efficiency was approximately equal for all genes, the transcript levels relative to L7 were determined and reported as means $\pm \mathrm{SD}$.

\subsection{Statistical analysis}

The results were expressed as average \pm SD. The Kruskal Wallis test (nonparametric statistic for multiple comparisons) was used for multi-group comparisons. Differences were considered statistically significant at $p<0.05$.

\subsection{Materials}

\section{Antibodies}

For western blot (WB), all antibodies were diluted in 5\% dry fat milk (milk powder, Roth) in TBST. Incubation with specific antibodies for WB occurred overnight at $4^{\circ} \mathrm{C}$. 
Secondary antibodies were diluted 1:10000 with $5 \%$ dry fat milk in TBST. For immunostaining, incubations occurred with specific antibodies (diluted in $5 \%$ BSA /TBST) for one hour at room temperature in dark chamber with humidified environment.

\begin{tabular}{|c|c|c|c|}
\hline Antibody & Company & Cat. No. & Aplication \\
\hline Hsp 60 & Stressgen, Ann Arbor, USA & SPA-805 & WB \\
\hline Cathepsin B & Santa Cruz, Germany & sc-13985 & WB \\
\hline Cytochrome C & Santa Cruz, Germany & sc-13156 & WB \\
\hline Hsc70 & Stressgen, Germany & SPA-819 & WB \\
\hline FTH1 (ferritin) & Cell Signaling, Germany & 3998 & WB \\
\hline $\begin{array}{l}\text { Histone diacetylase } 2 \\
(\mathrm{HDAC} 2)\end{array}$ & Cell Signaling, Germany & 2570 & WB \\
\hline LC3 & Novus Biologicals, Germany & NB100-2220 & WB \\
\hline P62 & Progen, Germany & GP62-C & WB \\
\hline B-Tubulin & Sigma, Germany & T8328 & WB \\
\hline $\begin{array}{l}\text { D237 } \\
\text { Keratin } 18 \text { (Asp 237) }\end{array}$ & $\begin{array}{r}\text { obtained from } \mathrm{MB} \mathrm{O} \\
55148 \mathrm{~A}, \text { Anna }\end{array}$ & & $\mathrm{WB}, \mathrm{IHC}$ \\
\hline
\end{tabular}




\section{Primers}

Primer pairs were designed as 19-21 mer and produced at Biomers. net GmbH, Germany.

Table 2.1. PCR Primers (5'-3') for Genotyping and Real-Time qRT-PCR

\begin{tabular}{|c|c|c|}
\hline \multicolumn{3}{|c|}{ Genotyping PCR } \\
\hline Primer & Forward & Reverse \\
\hline musHepc1KO-Scr-F1* & ggctgtagaggttctgctg & \multirow{3}{*}{ aacagataccacactgggaa } \\
\hline musHepc1KO-Scr-F2* & gctgaagaacgagatcagc & \\
\hline musHepc1KO-Scr-R* & & \\
\hline \multicolumn{3}{|c|}{ Real-time qRT-PCR } \\
\hline Primer & Forward & Reverse \\
\hline musHamp & ctgtctcetgettctcetcct & ggctgcagctctgtagtctgt \\
\hline musMCP1 & cgg ctg gag cat cca cgt gt & ctt tgg gac acc tgc $\operatorname{tgc} \operatorname{tgg} t$ \\
\hline mus collagen $1 a 1$ & tgaagaactggactgtcccaacc & gggtccctcgactcctacatctt \\
\hline mus TGFB & gcctgagtggctgtcttttga & gctgaatcgaaagccetgtatt \\
\hline mus STEAP3 & aactctgccetgattccaga & atagcagtgccttcgtggac \\
\hline mus DMT1 & catgctgacctctttcccag & ctggccagaataggttccag \\
\hline mus L7 & gaaaggcaaggaggaagctcatct & aatctcagtgcggtacatctgcct \\
\hline
\end{tabular}

* Genotyping of hepcidin knockout mice. 
Kits

\begin{tabular}{|c|c|}
\hline Item & Company \\
\hline 0,5\% Eosin G-solution & Merck, Germany \\
\hline Antigen Retrieval Solution & Vector Laboratories, INC., CA \\
\hline Bio-Rad DC Protein Assay & Bio-Rad Laboratories, Hercules, CA \\
\hline DNeasy Blood and Tissue Kit & Qiagen, Germany \\
\hline ECL Western Blotting Detection Reagent & $\begin{array}{l}\text { GE-Healthcare, Amersham } \\
\text { Biosc.,Munich }\end{array}$ \\
\hline Gene Ruler 50bp & Fermentas, Germany \\
\hline GoTaq Green Master Mix & Promega, Germany \\
\hline Haematoxylin solution & Dako, Germany \\
\hline In Situ Cell Death Detection Kit, POD & Roche, Germany \\
\hline RNase-Free DNase Set & Qiagen, Germany \\
\hline RNeasy Mini Kit & Qiagen, Germany \\
\hline SuperScript II Reverse Transcriptase & Invitrogen, Carlsbad \\
\hline SYBR Green PCR Master Mix & Applied Biosystems, Germany \\
\hline Vectastain ABC Kit & $\begin{array}{l}\text { Vector Laboratories; Inc, } \\
\text { Burlingame CA }\end{array}$ \\
\hline Vector Nova Red & Vector Laboratories, INC., CA \\
\hline Weigerts Iron haematoxylin solution & Merck, Germany \\
\hline
\end{tabular}

\section{Chemicals}

\begin{tabular}{|l|l|}
\hline \multicolumn{1}{|c|}{ Item } & \multicolumn{1}{c|}{ Company, ordering number } \\
\hline Acetic acid 100\% & VWR Prolabo, 20104.298, Germany \\
\hline Acrylamide 30\% & Roth, 3029.1, Germany \\
\hline
\end{tabular}




\begin{tabular}{|c|c|}
\hline Agarose & $\begin{array}{l}\text { Biozym, 840004, Germany, Lonza } \\
50004\end{array}$ \\
\hline Albumin bovine factor V (BSA) & Serva, 11930, Germany \\
\hline Ammonium persulphate & Sigma, A-3678, Germany \\
\hline $\begin{array}{l}\text { Bathophenanthrolinedisulfonic acid } \\
\text { disodium salt }\end{array}$ & Sigma, 146617, Germany \\
\hline $\begin{array}{l}\text { Bathophenanthrolinedisulfonic acid } \\
\text { disodium salt hydrate (BPT) }\end{array}$ & Sigma, B1375, Germany \\
\hline Bromphenol blue sodium salt & Sigma, B5525, Germany \\
\hline Chloramine-T trihydrate & Sigma, 31224, Germany \\
\hline Citric acid monohydrate & Calbiochem, 231211, Germany \\
\hline Coomassie Briliant blue R250 & Sigma, B0149, Germany \\
\hline Deoxynucleotides Set (dNTPs) & 5Prime, 2900340, Germany \\
\hline Direct red 80 & Sigma, 365548, Germany \\
\hline DL-Dithiothreitol (DTT) & Sigma, D9163, Germany \\
\hline EDTA & Roth, 8043.1, Germany \\
\hline Ehrlich's solution & Sigma, 03891, Germany \\
\hline Entellan & Merk, 1.07961.0100, Germany \\
\hline Ethanol & Sigma, 32.205, Germany \\
\hline Ethidium bromide & Sigma, E1510, Germany \\
\hline Glycerol & Roth, 7530.1, Germany \\
\hline Hydrochloric acid (HCL) $35 \%$ & VWR Prolabo, 20252.290, Germany \\
\hline Hydrogen peroxide $\left(\mathrm{H}_{2} \mathrm{O}_{2}\right)$ solution $30 \%$ & Fischer, 55760, Germany \\
\hline L-Ascorbic Acid & Sigma, 5960, Germany \\
\hline Methanol & Sigma, 32213, Germany \\
\hline
\end{tabular}




\begin{tabular}{|c|c|}
\hline Milk Powder & Roth, T145.2, Germany \\
\hline $\begin{array}{l}\text { MOPS(3-(N-Morpholino)propanesulfonic } \\
\text { acid, 4-Morpholinepropanesulfonic acid) }\end{array}$ & Sigma, M1254, Germany \\
\hline Nitrilotriacetic acid disodium salt & Sigma, N0128, Germany \\
\hline Nitrilotriacetic acid trisodium salt & Sigma, N0253, Germany \\
\hline Nonidet P40 (NP-40) & Roche, 11332473001, Germany \\
\hline Nycodenz & Progen, 1002424, Germany \\
\hline PBS Dulbecco & Biochrom, L182-50, Germany \\
\hline Phenylmethanesulfonylfluorid (PMSF) & Sigma, P-7626, Germany \\
\hline Potassium chloride & AppliChem, A2939, Germany \\
\hline Potassium Deoxycholate & Sigma, D9750, Germany \\
\hline Potassium hexacianoferrate (II) trihydrate & Sigma, P9387, Germany \\
\hline RNAlater & Ambion, AM7024, US \\
\hline Sodium dodecyl sulphate (SDS) & Roth, 2326,2, Germany \\
\hline Sodium thioglycolate (TGA) & Sigma, T0632, Germany \\
\hline ß-Mercaptoethanol & Sigma, M3148, Germany \\
\hline Sucrose & Sigma, S-0389, Germany \\
\hline TEMED (1,2-Bis(dimethylamino)ethane) & Sigma, T-7024, Germany \\
\hline Trans-4-hydroxy-L-proline standard & Sigma, 54409, Germany \\
\hline Tris & USB, 75825, Germany \\
\hline Tween 20 & Roth, 9127.1, Germany \\
\hline Xylol & VWR Prolabo, 28975.325, Germany \\
\hline
\end{tabular}


Other

\begin{tabular}{|l|l|}
\hline \multicolumn{1}{|c|}{ Item } & \multicolumn{1}{c|}{ Company, ordering number } \\
\hline AmiconUltra centrifuge tube & Millipore, 42422, Germany \\
\hline MicroAmp Fast Optical 96well Reaction & Applied Biosystems, 4346906, Germany \\
\hline MicroAmp Optical Adhesive Film & Applied Biosystems, 4311971, Germany \\
\hline PVDF membrane & Millipore, IPVH00010, Germany \\
\hline Random primers & Invitrogen, 48190-011, Germany \\
\hline SuperFrost Plus microscope slides & ThermoScientific, J1800AMNZ, Germany \\
\hline D12450B with 3\% carbonyl iron & Ssniff, Germany \\
\hline Ultracentrifuge tubes & B2B/Beckmann Coulter, 344059, \\
& Germany \\
\hline
\end{tabular}

\section{Laboratory equipment}

\begin{tabular}{|l|l|}
\hline \multicolumn{1}{|c|}{ Item } & \multicolumn{1}{c|}{ Company } \\
\hline s500 Fast Real-Time PCR System, with & \\
Software, Version 1.4 & AppliedBiosystems, Germany \\
\hline Block thermostate & \\
\hline Centrifuge 5417C & Biostep GmbH, Jahnsdorf, Germany \\
\hline Centrifuge 5417R & Eppendorf, Germany \\
\hline Deep freezer & Eppendorf, Germany \\
\hline DNAEngine Piltier Thermal Cycler & Bio-Rad Lab, USA \\
\hline Gel electrophoresis equipment and & Bio-Rad Laboratories, USA \\
\hline accessories & \\
\hline Homogenisator & VWR 432-5032, Germany \\
\hline
\end{tabular}




\begin{tabular}{|l|l|}
\hline Ice machine AF200 & Scotsman, Germany \\
\hline Microscope light & Leica Mikrosysteme Vertrieb GmbH, with \\
& $\begin{array}{l}\text { sofware ',Leica application suite', } \\
\text { Wetzlar, Germany }\end{array}$ \\
\hline MS3 Minishaker (Vortex) & IKA, Staufen, Works Inc., Germany \\
\hline NanoDrop 1000 & Thermo Scientific, Schwerte, Germany \\
\hline pH-Meter DRI-Block & Biostep GmbH, Jahnsdorf, Germany \\
\hline Photometer Ultrospec 1100 pro & GE Healthcare, München, Germany \\
\hline Pipet boy & Hirschmann Lab equipment, Germany \\
\hline Pipets & Eppendorf, Germany \\
\hline Power supply & Bio-Rad Laboratories, USA \\
\hline Scale PM 4000 & Mettler-Toledo GmbH, Giessen, Germany \\
\hline Sorvall Ultracentrifuge OTD 50B & DuPONT, Germany \\
\hline Waterbath & Laboratory technology, Germany \\
\hline
\end{tabular}

\section{General buffers}

\section{TAE Buffer pH 8:}

$40 \mathrm{mM}$ Tris

$20 \mathrm{mM}$ acetic acid

$1 \mathrm{mM}$ EDTA

\section{Homogenisation buffer:}

SDS(Sodium dodecyl sulphate) $\quad 3 \%$

Tris $\mathrm{pH} \mathrm{7,8}$

$50 \mathrm{mM}$

Potassium chloride

$150 \mathrm{mM}$

Nonidet P 40

$1 \%$

Potassium deoxycholate 
Spermidine

$25 \mu \mathrm{g} / \mathrm{ml}$

0,1 \% Coomassie brilliant blue buffer :

Coomassie brilliant blue $\quad 1 \mathrm{~g}$

Methanol $\quad 500 \mathrm{ml}$

Acetic acid $\quad 100 \mathrm{ml}$

Distilled water $\quad 400 \mathrm{ml}$

$10 \times$ TBS, $\mathbf{p H}=7,6$ :

Tris

$24.2 \mathrm{~g}$

$\mathrm{NaCl}$

$80 \mathrm{~g}$

Distilled water till

$1000 \mathrm{ml}$

1 x TBS:

10xTBS $100 \mathrm{ml}$

Distilled water $\quad 900 \mathrm{ml}$

TBST:

10x TBS

$100 \mathrm{ml}$

Distilled water

$900 \mathrm{ml}$

Tween 20

$1 \mathrm{ml}$

APS (Ammonium persulphate) $10 \%$ :

Ammonium persulphate

$0.1 \mathrm{~g}$

Distilled water $1000 \mu 1$

SDS (Sodium dodecyl sulphate)10 \% :

SDS

$10 \mathrm{~g}$

Distilled water

$100 \mathrm{ml}$

Resolving gel buffer:

Tris base

$181.71 \mathrm{~g}$

Distillate water

$500 \mathrm{ml}$ 
pH to 8.8 (with HCL)

Distilled water till

$1 \mathrm{~L}$

Stacking gel buffer:

Tris base

$60.5 \mathrm{~g}$

Distillate water

$600 \mathrm{ml}$

$\mathrm{pH}$ to 6.8 (with $\mathrm{HCl}$ )

Distilled water till

$1 \mathrm{~L}$

4 x SDS Loading Buffer(Laemmli buffer):

$1 \mathrm{M}$ TrisCl$(\mathrm{pH} 6,8)$

$1.5 \mathrm{ml}$

1M DTT

$3 \mathrm{ml}$

SDS

$0.6 \mathrm{~g}$

Bromophenol blue

$0.03 \mathrm{~g}$

$100 \%$ Glycerol

$3 \mathrm{ml}$

10 x Gel Running Buffer:

SDS

$50 \mathrm{~g}$

Tris Base

$150 \mathrm{~g}$

Glycine

$720 \mathrm{~g}$

Distillate water

$4 \mathrm{~L}$

Heat up at $70-80^{\circ} \mathrm{C}$ in a waterbath to dissolve the chemicals

Add distillate water till

$5 \mathrm{~L}$ 
10 x Transfer Buffer:

Tris base

$30.48 \mathrm{~g}$

Glycine

$72.1 \mathrm{~g}$

Add distillate water till 1L

1 x Transfer Buffer:

10xTransfer Buffer

$100 \mathrm{ml}$

Methanol

$200 \mathrm{ml}$

Distillate water

$700 \mathrm{ml}$

10\% SDS Resolving gel:

\begin{tabular}{|l|c|}
\hline $\mathrm{H}_{2} \mathrm{O}, \mathrm{ml}$ & 2.05 \\
\hline Resolving gel buffer, $\mathrm{ml}$ & 1.3 \\
\hline $30 \%$ Acrylamide, $\mathrm{ml}$ & 1.65 \\
\hline $10 \% \mathrm{SDS}, \mu \mathrm{l}$ & 50 \\
\hline $10 \%$ APS, $\mu \mathrm{l}$ & 25 \\
\hline TEMED, $\mu \mathrm{l}$ & 7.5 \\
\hline
\end{tabular}

Stacking gel:

\begin{tabular}{|l|c|}
\hline $\mathrm{H}_{2} \mathrm{O}, \mathrm{ml}$ & 1.5 \\
\hline Stacking gel buffer, $\mathrm{ml}$ & 0.65 \\
\hline $30 \%$ Acrylamide, $\mu \mathrm{l}$ & 375 \\
\hline $10 \%$ SDS, $\mu \mathrm{l}$ & 25 \\
\hline $10 \%$ APS,$\mu \mathrm{l}$ & 12.5 \\
\hline TEMED, $\mu \mathrm{l}$ & 2.5 \\
\hline
\end{tabular}




\section{Results}

\subsection{Phenotypic analysis of Hepcidin 1 knockout mouse}

To study the mechanism of iron overload associated liver injury, hepcidin knockout mice were used, given that hepcidin represents the central regulator of iron metabolism and human hepcidin mutations leads to a particularly severe disease $[15,16]$. To that end, we used previously described hepcidin knockout mice generated by replacing exons 1, 2 and part of exon 3 with hygromycin resistance cassette using homologous recombination in Embryonic Stem cells (Figure 4.1.A) [54]. Hepcidin heterozygous mice were bred together in order to obtain hepcidin knockout animals and their non - transgenic littermates. The genotyping was done via PCR (Figure 4.1.B) and the lack of hepcidin expression was confirmed by RT - PCR (Figure 4.1.C) analysis. 

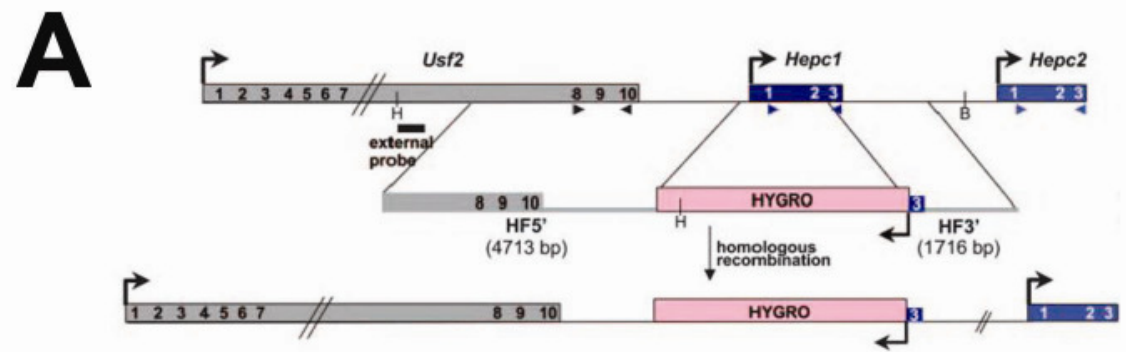

\section{0bp WT HT KO HT KO WT Blank 50bp}
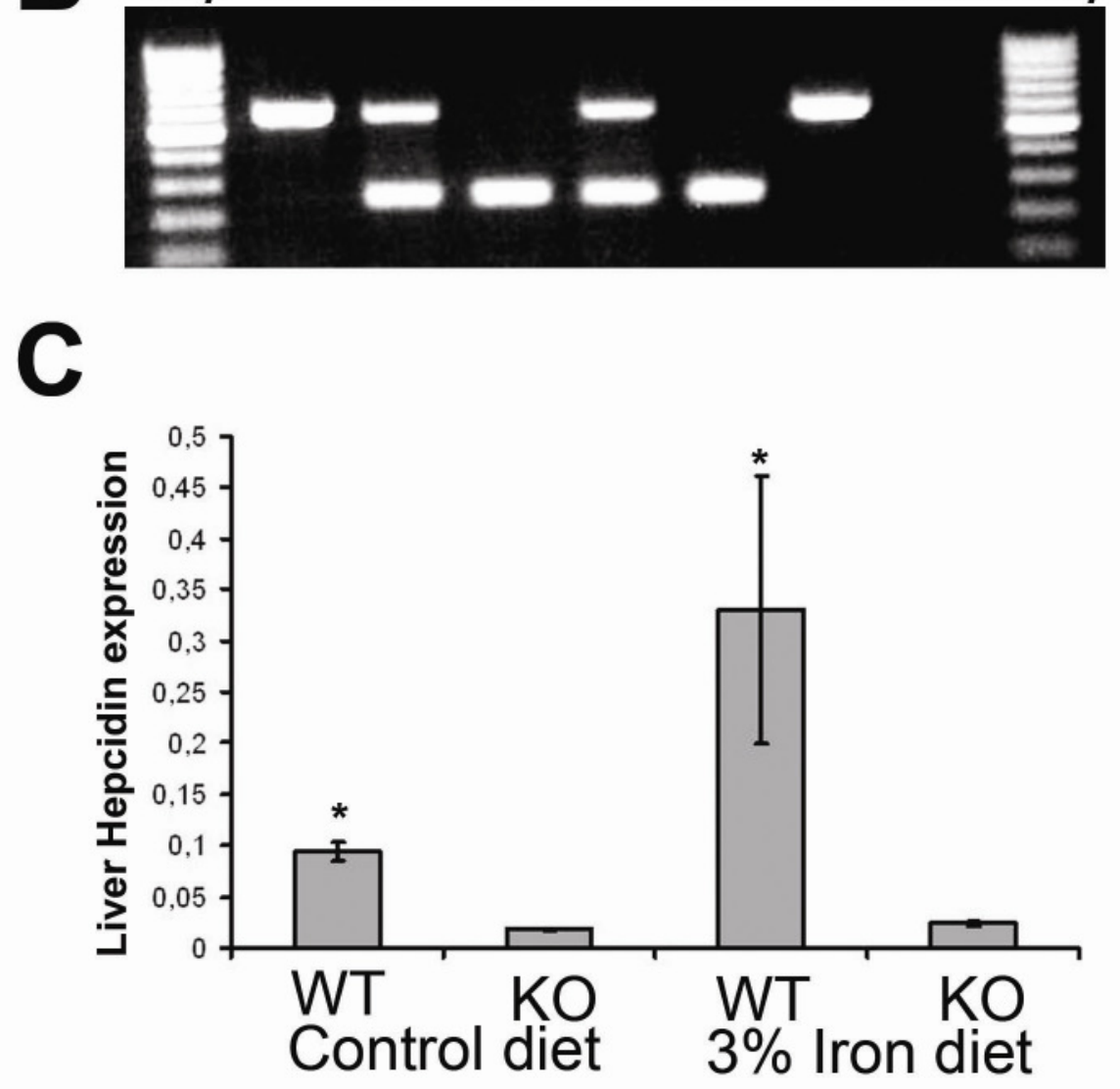

Figure 4.1. Genotypic analysis of Hepcidin 1 knockout mouse. A) Schematic presentation of generation hepcidin 1 knockout mouse. The gene locus containing Usf2, Hepc 1, and Hepc 2 genes is shown on the top, the targeting construct in the middle and the resulting - targeting allele at the bottom. The genes are depicted as colour boxes and arrows highlight the direction of transcription; modified from Lesbordes-Brion et al, 2006. B) Genotyping of transgenic mice via PCR. C) Determination of hepcidin transcript levels using real time RT - PCR. Results are expressed as mean \pm SD $(n=5) p<0.05$. 


\subsection{Experimental iron overload model}

To further increase the iron accumulation in hepcidin knockout mice feeding of them ironrich (3\% iron carbonyl - containing diet) diet $[118,119,120]$ was started at the age of 28 days (Figure 4.2.). Control animals were fed standard chow containing approximately 0.02 $\%$ of iron (Ssniff). To study the influence of iron overload on hepcidin level in hepcidin WT mice real time RT - PCR was performed (Figure 4.1.C). In six months old animals fed iron-rich diet, were observed significantly higher hepcidin transcript levels that in mice kept on control diet. Of note, the levels of hepcidin expression were negligible in hepcidin KOs regardless of the treatment regimen.

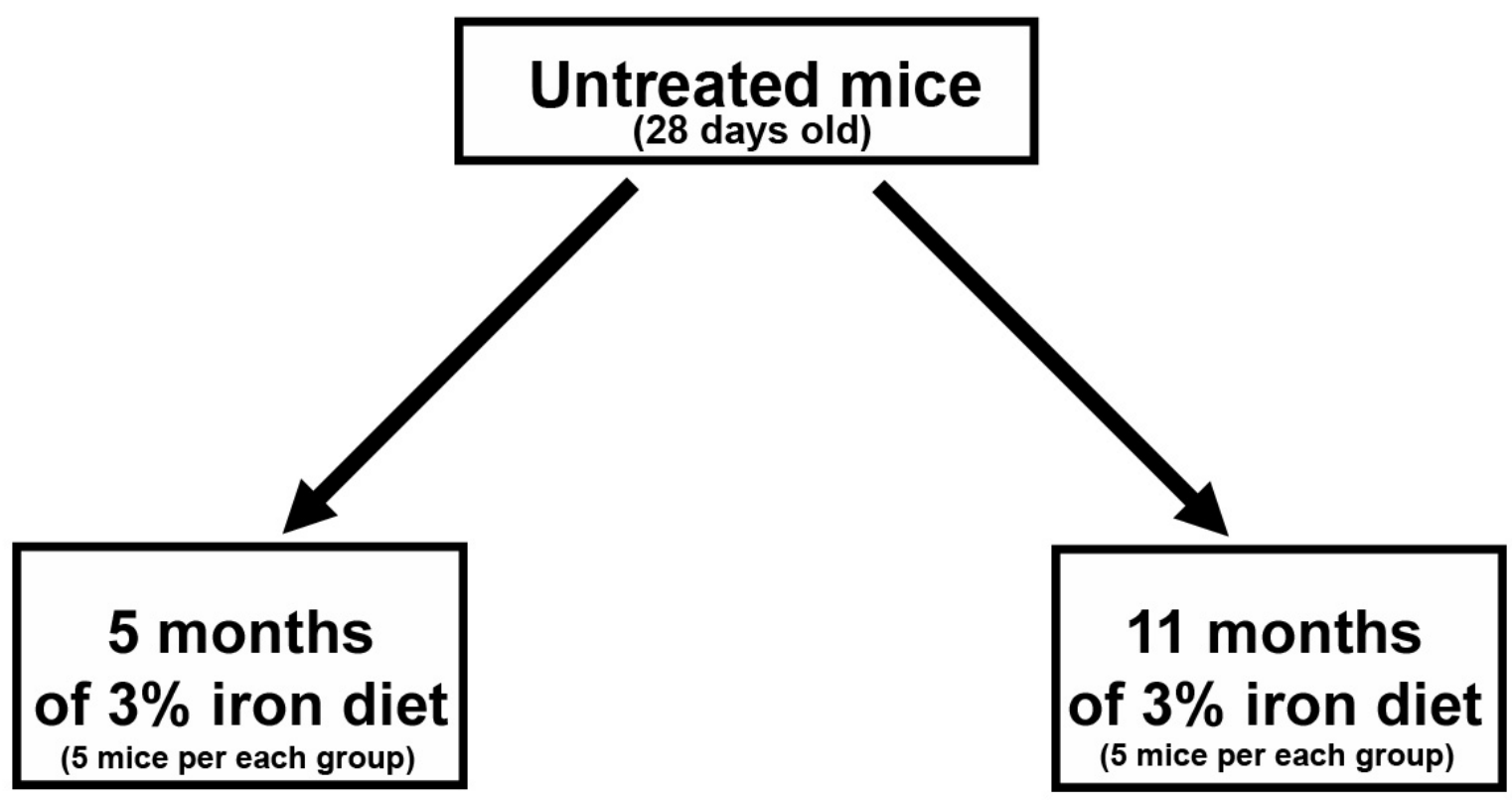

Figure 4.2. Schematic view of the chronic iron overload model. 28 days old hepcidin knockout and wild type mice were placed on $3 \%$ iron - carbonyl containing (latter like iron-rich) diet or standard chow for 5 and 11 months after which they were sacrificed and analysed. At least 5 mice were used per each group. 


\subsection{6 months old hepcidin knockout mice on iron-rich diet display elevated transaminases levels}

Liver injury was assessed by measuring serum ALT, AST, and AP levels (Figure 4.3. A,B,C). In mice fed standard diet, serum ALT, AST, and AP levels remained within the normal range for both genotypes. After 5 months of iron-rich diet, serum ALT, AST, and AP activity were moderately, but significantly increased in Hepcidin KO mice but not WT animals (Figure 4.3. A,B,C).
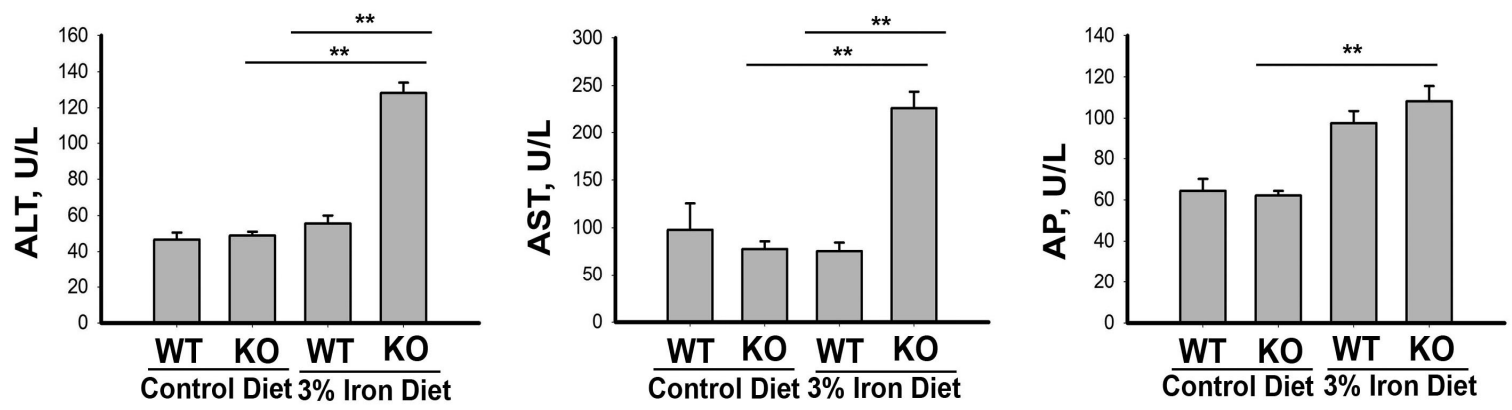

Figure 4.3. Hepcidin knockout mice display elevated transaminases levels after 6 months of iron-rich diet. ALT (A), AST (B), and AP (C) which were used as biochemical markers of liver injury display a moderate increase in hepcidin KO mice after 5 months of iron-rich diet. On the other hand, hepcidin KO mice kept on normal chow do not develop elevated transaminases. Results are shown as mean $\pm \operatorname{SD}(n=5)$. Double asterisk indicate results with $\mathrm{p}<0.05$. 


\subsection{Hepcidin knockout mice show elevated serum iron parameters}

As reported previously [54], 6 months old hepcidin KO mice kept on standard diet display higher serum ferritin levels, while no differences were observed in serum iron (Frigure 4.4.). On the other hand serum ferritin levels were comparable in 6 months old WT mice kept on iron-rich diet and hepcidin KOs on standard chow, whereas hepcidin KO mice on iron - rich diet showed clearly the highest serum iron and ferritin levels. Furthermore, the hepatic NTBI levels were analysed, given that NTBI represents the most reactive iron subpool. Among the mice on standard diet, hepcidin KO mice display significantly higher NTBI levels which were clearly higher than the levels seen in WT mice on iron-rich diet. Of note, feeding with iron-rich diet resulted in an approximately two fold increase of NTBI levels in hepcidin KO mice. 

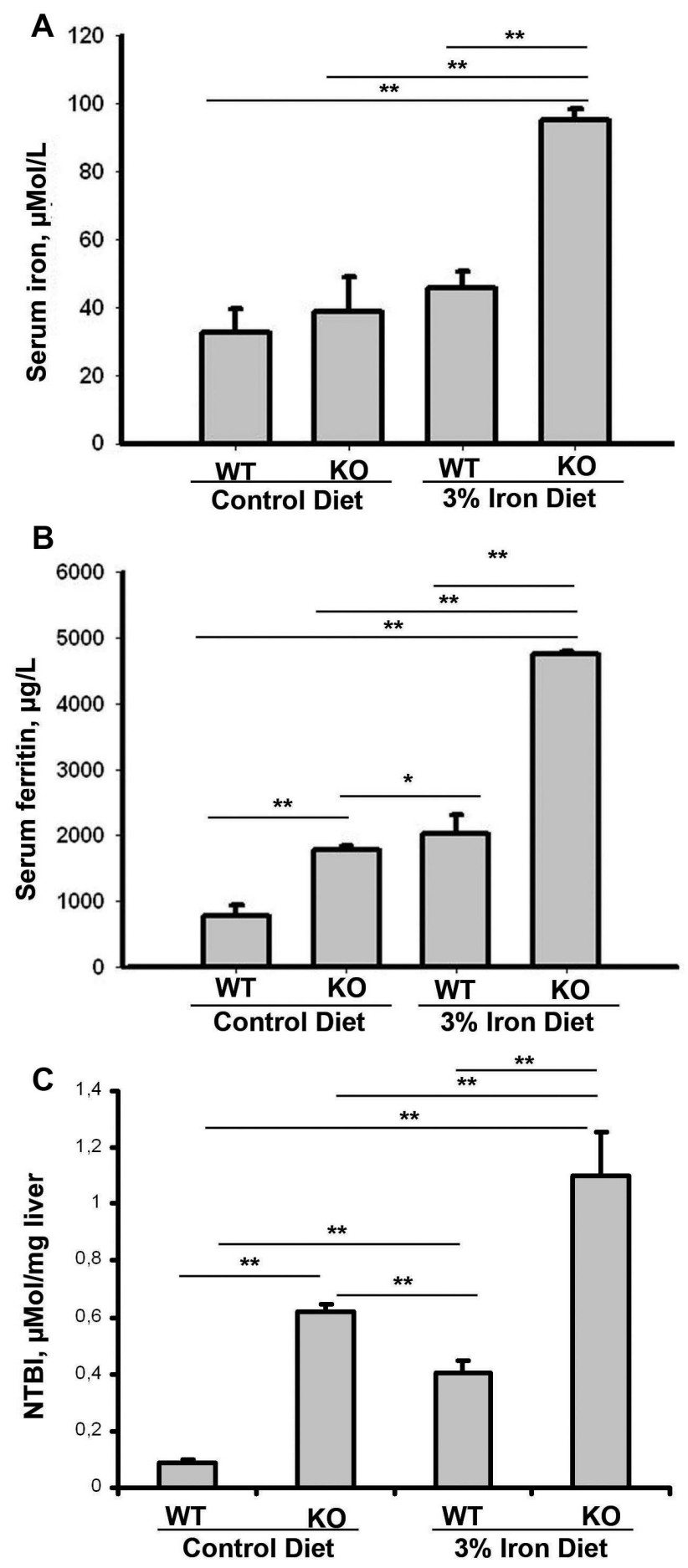

Figure 4.4. Hepcidin knockout mice show elevated serum iron parameters as well as hepatic NTBI levels. The graph summarizes findings obtained from 6 months old hepcidin WT and KO mice kept on normal and iron-rich diet. Note that serum iron (A) and ferritin (B) levels dramatically increased in hepcidin KO mice after treatment with iron-rich diet. C) Hepatic NTBI levels were significantly upregulated in hepcidin KO mice kept on normal diet and further increased in KOs fed iron-rich diet. Results are expressed as mean $\pm S D(n=5)$ and double asterisk indicate results with $\mathrm{p}<0.05$. 


\subsection{Accelerated and ubiquitous iron accumulation in 6 months old hepcidin knockout mice fed iron-rich diet}

To reveal the iron distribution in hepcidin knockout mice, Prussian Blue staining was performed. Hepcidin WT mice kept on standard diet showed no obvious iron accumulation (figure 4.5.A). In contrast to that, hepcidin knockout mice on standard diet displayed a marked iron overload throughout the liver (Figure 4.5.B). Hepcidin WT mice on iron-rich diet developed prominent iron accumulation in the periportal area (Figure 4.5.C). The highest iron accumulation was detected in hepcidin $\mathrm{KO}$ mice fed iron-rich diet (figure 4.5.D). These mice showed a fairly homogeneous iron distribution throughout the liver lobes, but in contrast to the other groups displayed often with rather fine iron staining big iron complexes. To determine the precise extent of iron accumulation total non - heme liver iron content was quantified (Figure 4.5.E). Hepcidin WT mice kept on standard diet harboured low amount of iron (level below $200 \mu \mathrm{g} / \mathrm{mg}$ tissue) comparable to the previously reported values [54]. On the other hand, hepcidin KO mice kept on standard diet displayed significantly increased iron content: $1444 \pm 102 \mu \mathrm{g} / \mathrm{mg}$ (Figure 4.5.E) which was comparable to the amount of iron observed in WT animals on iron-rich diet: $1493 \pm 136$ (Figure 4.5.E). The highest liver iron accumulation was seen in hepcidin KO mice on ironrich diet: $2543 \pm 14$ (figure 4.5.D,E). In summary, hepcidin KO mice displayed accelerated iron accumulation as well as altered iron distribution. 


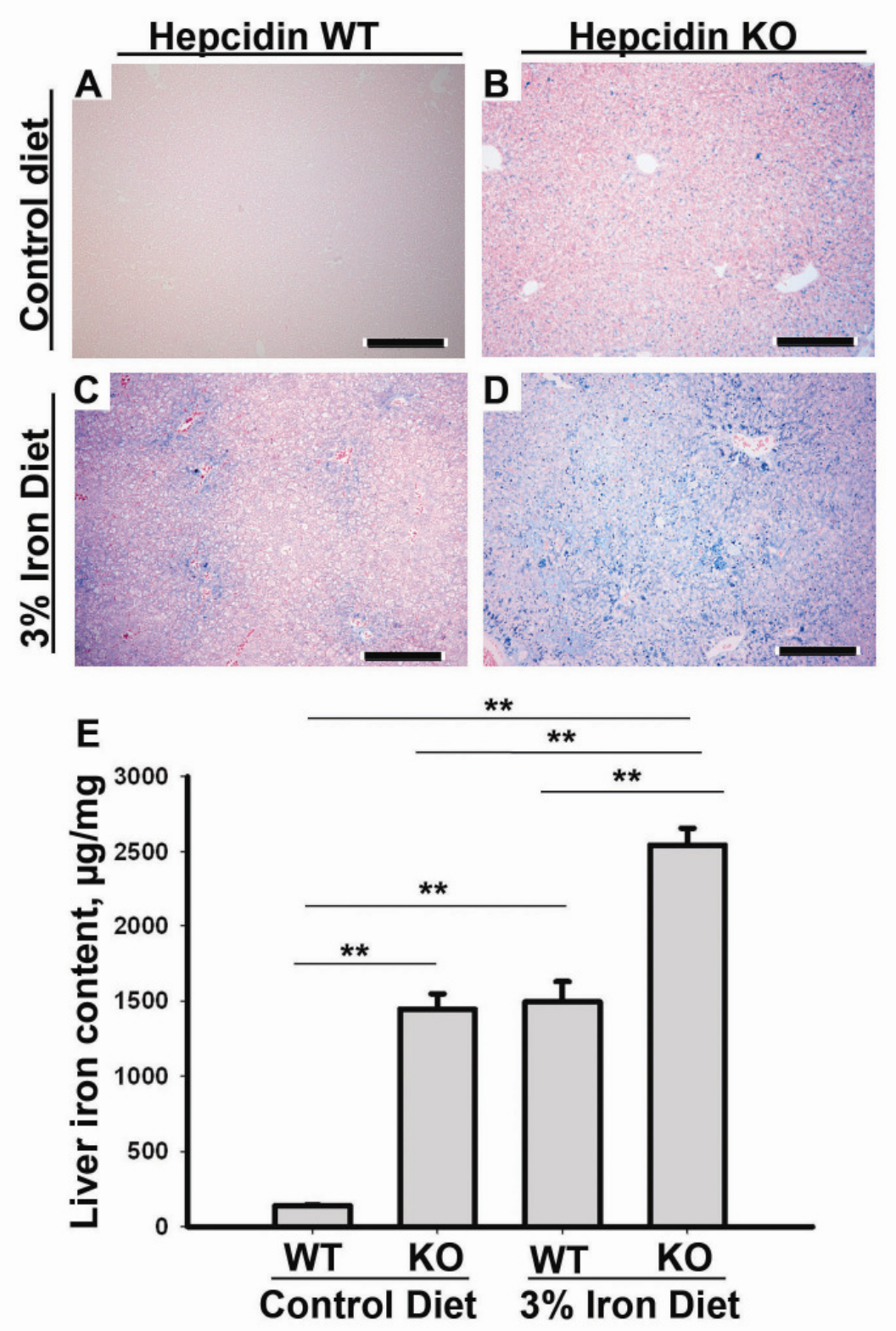

Figure 4.5. Accelerated and ubiquitous iron accumulation in hepcidin knockout mice. Hepcidin WT (A, C) and $\mathrm{KO}$ mice (B, D) were fed normal (A, B) or iron-rich diet (C, D) for 5 months. Scale bar $200 \mu \mathrm{m}$. E) Biochemical determination of non - heme liver iron content. Note, that hepcidin KO mice on iron-rich diet showed dramatic elevation of liver iron content. Results are expressed as mean \pm SD $(n=5)$ and double asterisk highlights $\mathrm{p}<0.05$. Both, hepcidin $\mathrm{KO}$ mice on iron-rich and normal chow developed iron overload, but mice on iron-rich diet accumulated significantly more of iron in the liver. Furthermore, iron is distributed homogeneously throughout the liver in hepcidin $\mathrm{KO}$ mice and occasionally forms large complexes, while WT animals displayed fine and show primary periportal iron staining. 


\subsection{6 months old hepcidin knockout mice develop mild liver injury}

In order to characterize the liver injury in hepcidin KO and WT mice, was performed H\&E staining (figure 4.6.A-D). On normal diet, hepcidin WT as well as hepcidin KO mice did not show any obvious pathologies in the liver (figure 4.6.A,B). After feeding with ironrich diet, hepcidin KO but not WT mice displayed a mild liver inflammation (Figure 4.6.D), which was confirmed by morphometric analysis (Figure 4.6.E).
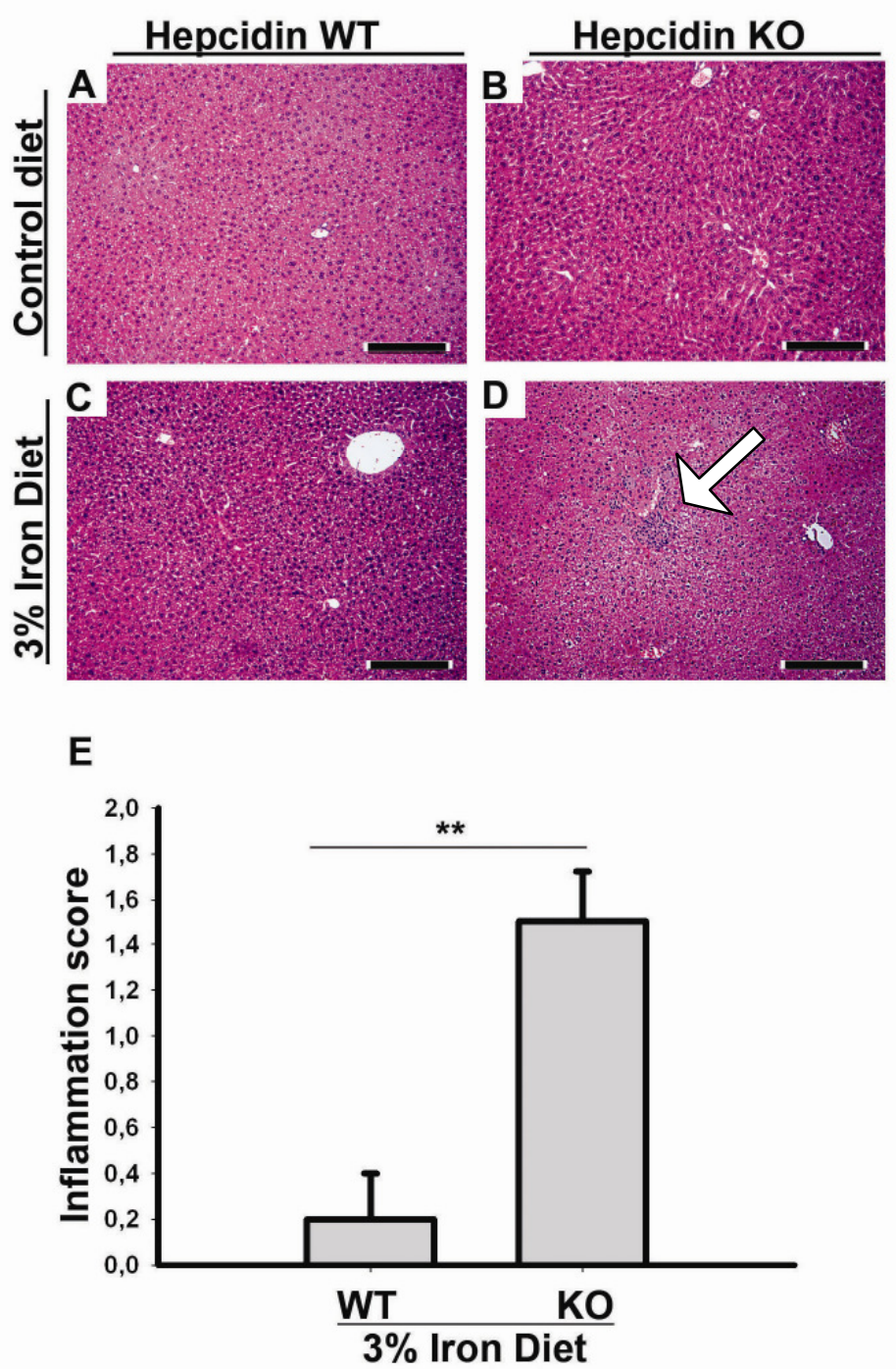

Figure 4.6. Hepcidin knockout mice fed iron-rich diet develop mild liver injury. Representative mouse liver tissues from hepcidin WT mice $(\mathrm{A}, \mathrm{C})$ and hepcidin $\mathrm{KO}$ mice $(\mathrm{B}, \mathrm{D})$ were fed either normal chow (A, B) or iron-rich diet (C, D) for 5 months and were stained with H\&E. Scale bar $200 \mu \mathrm{m}$. E) Morphometric analysis of liver inflammation. Results are shown as mean \pm SD $(n=5)$ and asterisk highlights $\mathrm{p}<0.05$. Note, that hepcidin knockouts fed with iron-rich diet develop liver injury. 


\subsection{6 months old hepcidin knockout mice fed iron-rich diet display a mild chronic elevated expression of inflammatory cytokines}

To study the factors leading to liver inflammation in hepcidin $\mathrm{KO}$ animals, the expression levels of selected proinflammatory cytokines were analyzed by real time PCR. Compared to nontransgenic mice on control diet non - treated hepcidin KOs and WT mice on ironrich diet displayed diminished MCP1 levels, while KOs on iron-rich diet displayed significant increase in MCP1 production (Figure 4.7.). Similarly, TGF $\beta$ was unaltered in mice on control diet or in WT animals fed iron-rich food, but was significantly elevated in hepcidin $\mathrm{KO}$ mice on iron-rich diet. Therefore, it was concluded that hepcidin knockout mice showed production of inflammatory cytokines when fed iron-rich diet.

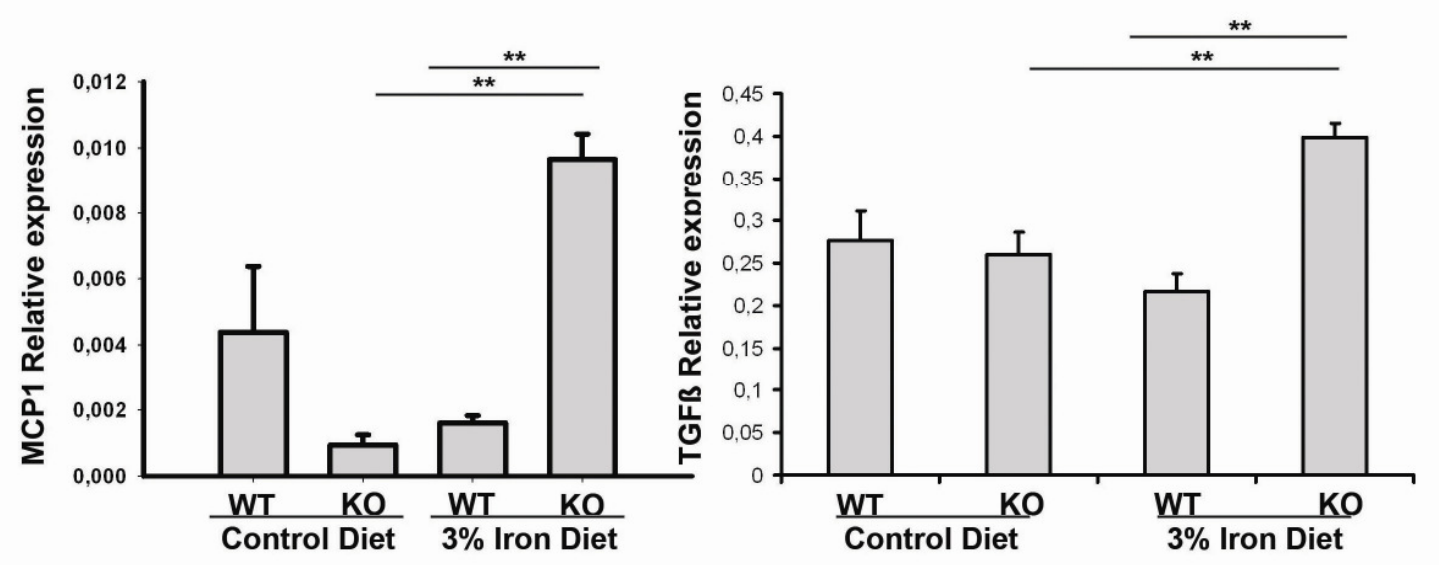

Figure 4.7. Hepcidin knockout mice on iron-rich diet display elevated expression of inflammatory cytokines. Hepcidin $\mathrm{KO}$ mice on iron-rich diet showed significantly increased expression of Monocyte chemoatractant protein - MCP - 1 (A) and Transforming growth factor beta - TGFß (B) as determined by real time RT - PCR. Results are shown as mean \pm SD $(n=5)$ and double asterisk highlights $\mathrm{p}<0.05$.

\subsection{Hepcidin knockout mice on iron-rich diet display elevated liver apoptosis}

The initial histologic evaluation suggested elevated amount of apoptotic hepatocytes in hepcidin $\mathrm{KO}$ mice on iron-rich diet which was supported by morphometric analysis (Figure 4.8.E). To further confirm these findings, was performed IHC staining with D237 antibody (Figure 4.8.A-B), which recognizes the caspase - cleaved keratin 18 fragment [110]. Hepcidin KO mice fed iron-rich diet showed a marked increase in apoptotic level 
(figure 4.8.D), while only minimal apoptosis was seen in the other groups (Figure 4.8. D). These findings were further substantiated by immunoblot analysis with the same antibody, which displayed clearly elevated apoptosis levels in hepcidin KO mice on iron-rich diet, while only moderately elevated apoptosis was seen in hepcidin $\mathrm{KO}$ mice on standard diet or WTs fed iron-rich chow (Figure 4.8.F).

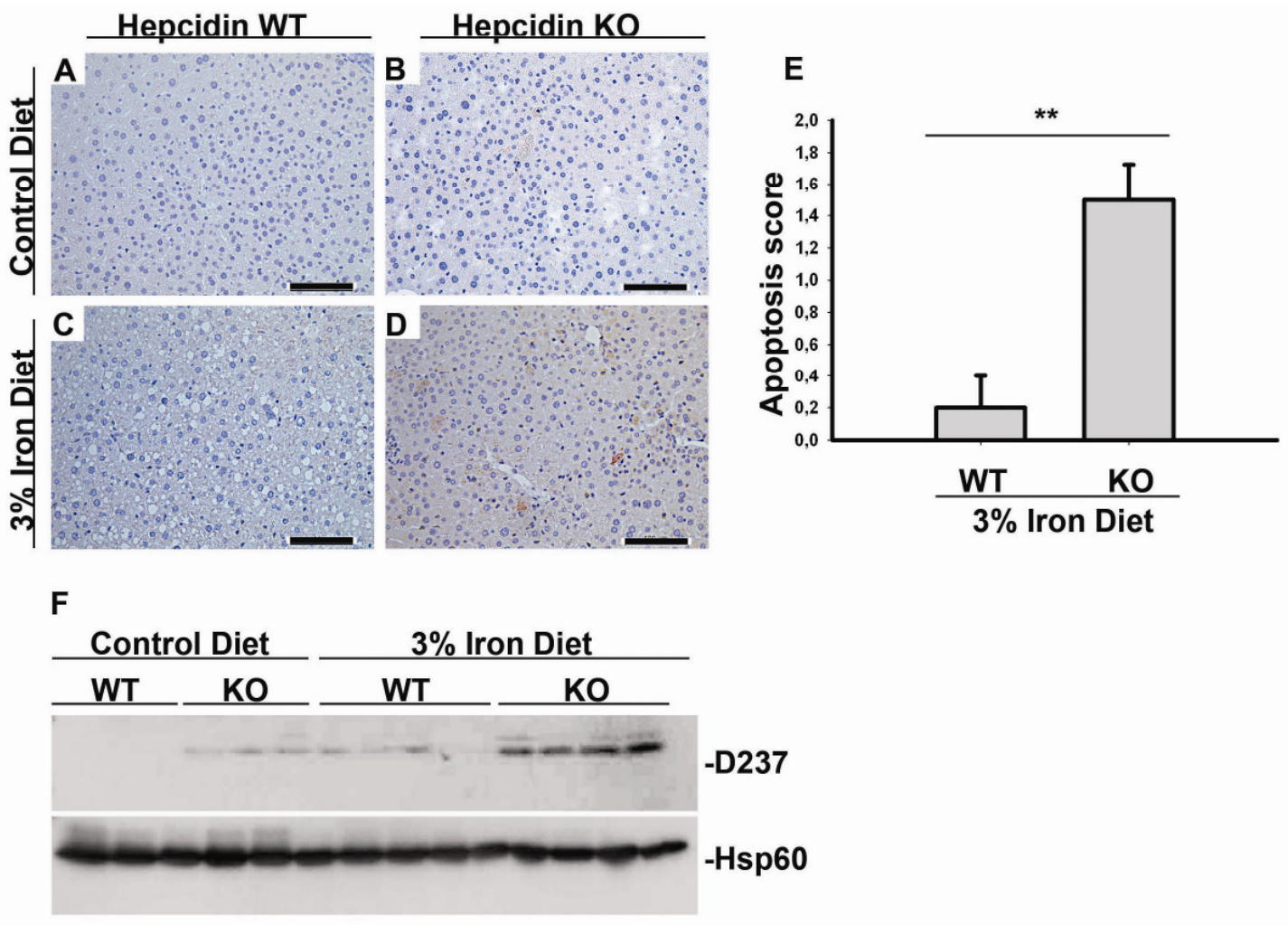

Figure 4.8. Iron-rich diet leads to activation of apoptosis in hepcidin knockout mice. Immunohistochemistry staining was carried out on liver tissues (A - D) with D237 antibody detecting a caspase - cleaved keratin 18 fragment. 6 months old hepcidin WT (A, C) and KO mice (B, D) fed normal chow (A, B) and iron-rich diet (C, D) were analyzed. Scale bar $200 \mu \mathrm{m}$. E) The extent of liver apoptosis was scored in H\&E stained liver sections and results were presented as mean \pm SD $(n=5)$ and asterisk highlights $\mathrm{p}<0.05$. Extent of apoptosis was determined by immunoblot analysis (F) using D237 antibody. Hsp 60 was used as a loading control. 


\subsection{6 months old hepcidin knockout mice fed iron-rich diet show signs of hepatic stellate cells activation, but no significant liver fibrosis}

To test, whether hepcidin KO mice with chronic iron overload develop liver fibrosis, Sirius red staining, hydroxyproline assay, and collagen real time PCR were performed (figure 4.9.A-F). Using these methods, significant elevation of collagen expression in hepcidin knockout mice on iron - rich diet was detected (figure 4.9.F), thereby showing HSCs activation. However, 6 months old hepcidin $\mathrm{KO}$ mice fed iron-rich diet did not show a significant collagen deposition as confirmed by Sirius red staining and hydroxyproline assay (figure 4.9.A-E).

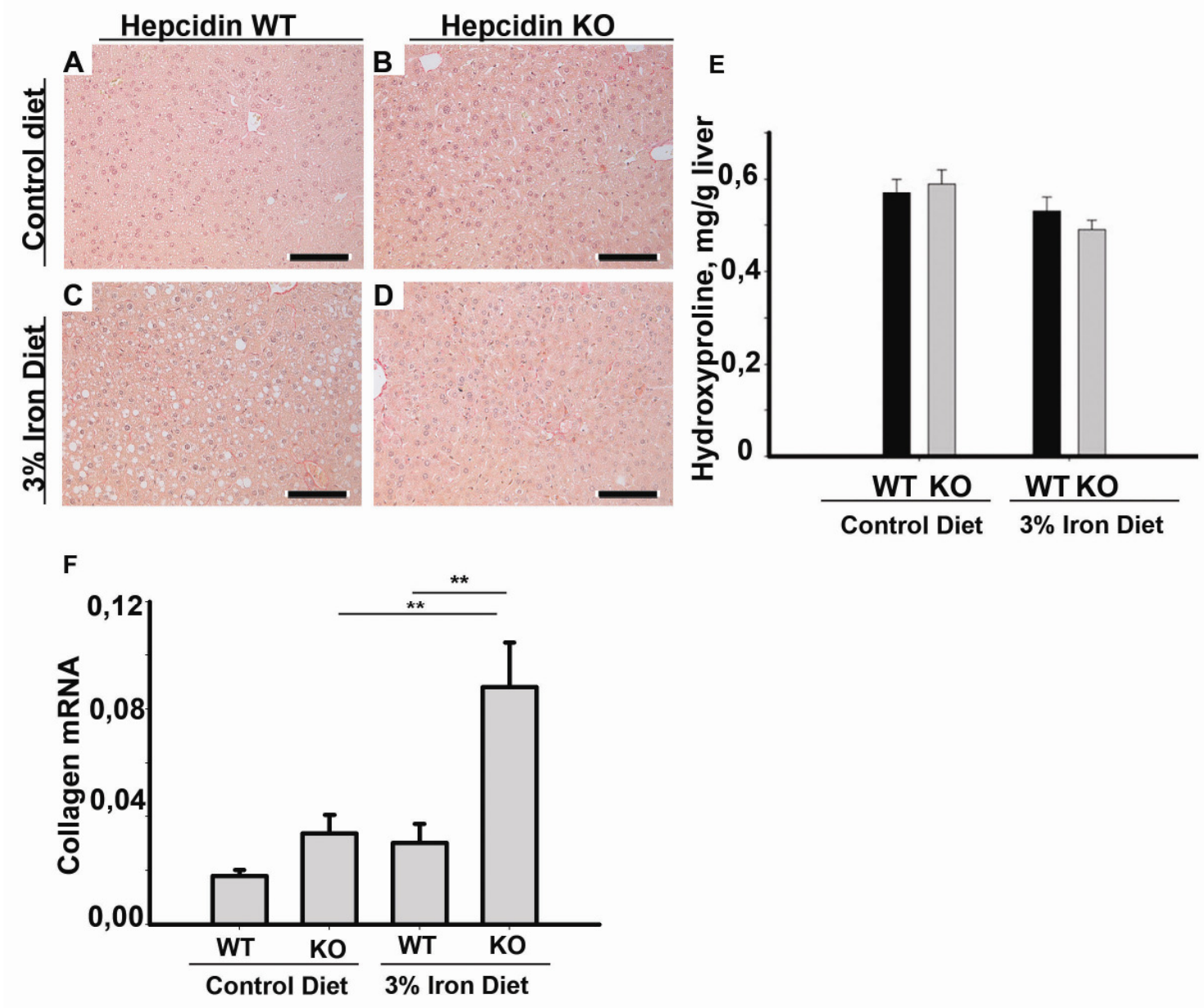

Figure 4.9. 6 months old hepcidin knockout mice fed iron-rich diet show signs of stellate cells activation, but not significant liver fibrosis development. Sirius red staining of liver sections from hepcidin WT (A, C) and KO mice (B, D) fed with iron-rich (C, D) or kept on standard chow (A, B). Scale bar $100 \mu \mathrm{m}$. Liver hydroxyproline content was measured in hepcidin KO and WT mice on both, iron-rich and 
standard chow $(E)$ and results were presented as mean \pm SD $(n=5)$. Collagen mRNA level was determined using real time RT - PCR and data are shown as mean \pm SD. Double asterisk highlights $\mathrm{p}<0.05$.

\subsection{2 months old, iron-rich diet fed hepcidin knockout mice develop moderate liver injury}

To study the effect of even more pronounced iron overload, mice were kept on iron-rich diet until the age of 12 months and serum ALT, AST and AP were measured (Figure 4.10.A, B, C). In mice on normal diet as well as in WT animals on iron-rich diet, ALT, AST, and AP levels were not grossly elevated and did not show any obvious differences between the groups. On the other hand, all parameters were clearly elevated in hepcidin KO mice kept on iron-rich diet (Figure 4.10.A, B, C). Therefore, it was concluded that hepcidin KO mice on iron-rich diet showed significant signs of liver injury.
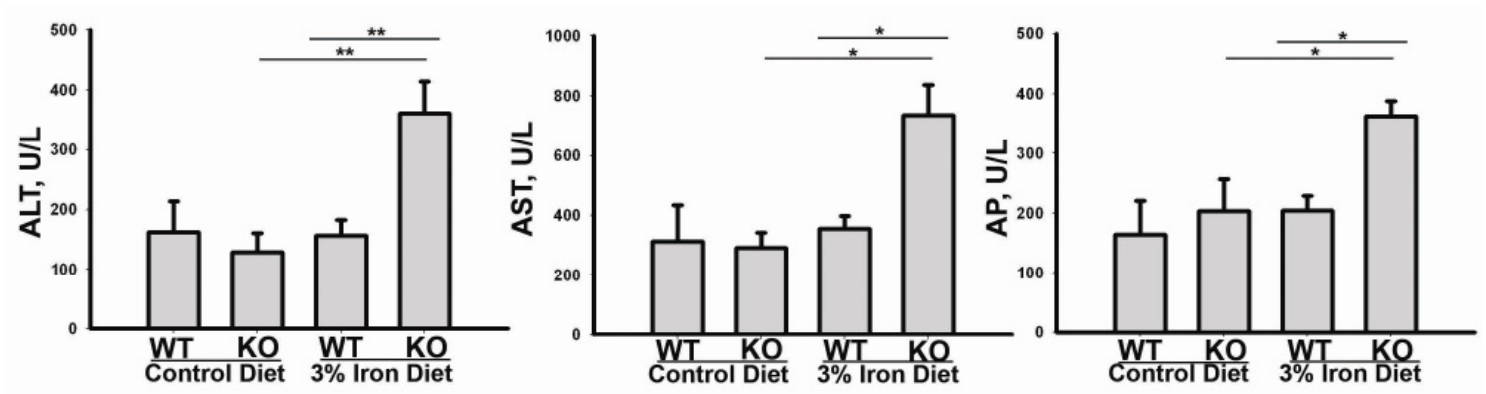

Figure 4.10. 12 months old hepcidin knockout mice fed iron-rich diet develop obvious liver injury.

Serum ALT (A), AST (B), and AP (C) levels were determinated in hepcidin WT and KO mice kept on normal or iron-rich diet. Note, that all parameters are significantly increased in hepcidin knockouts on ironrich diet. Results are presented as mean \pm SD. Asterisk and double asterisk highlights $\mathrm{p}<0.05$ and $\mathrm{p}<0.005$, respectively. 


\subsection{Hepcidin knockout mice develop progressive iron overload at 12 months}

To evaluate the mechanism of liver injury in these animals, selected parameters of iron metabolism were quantified. Serum iron levels in mice kept on standard diet as well as WT mice on iron-rich diet remained within the normal ranges with values below $100 \mu \mathrm{M} / \mathrm{L}$. However, iron-rich diet led to dramatic increase in serum iron levels in hepcidin $\mathrm{KO}$ mice (Figure 4.11.A). Furthermore, hepcidin KO mice and their nontransgenic littermates kept on normal diet show comparable ferritin levels. On the other hand, when fed iron-rich diet, both genotypes developed significant increase of serum ferritin (figure 4.11.B) which was more pronounced in hepcidin KO mice. Moreover, measurement of liver NTBI showed a moderate increase in NTBI levels in hepcidin KO mice on normal as well as WT mice on iron-rich diet, while grossly elevated NTBI levels were seen in hepcidin KO mice on ironrich diet (figure 4.11.C). Taken together, hepcidin $\mathrm{KO}$ mice developed massive iron overload when fed with iron-rich diet over a long period of time. 

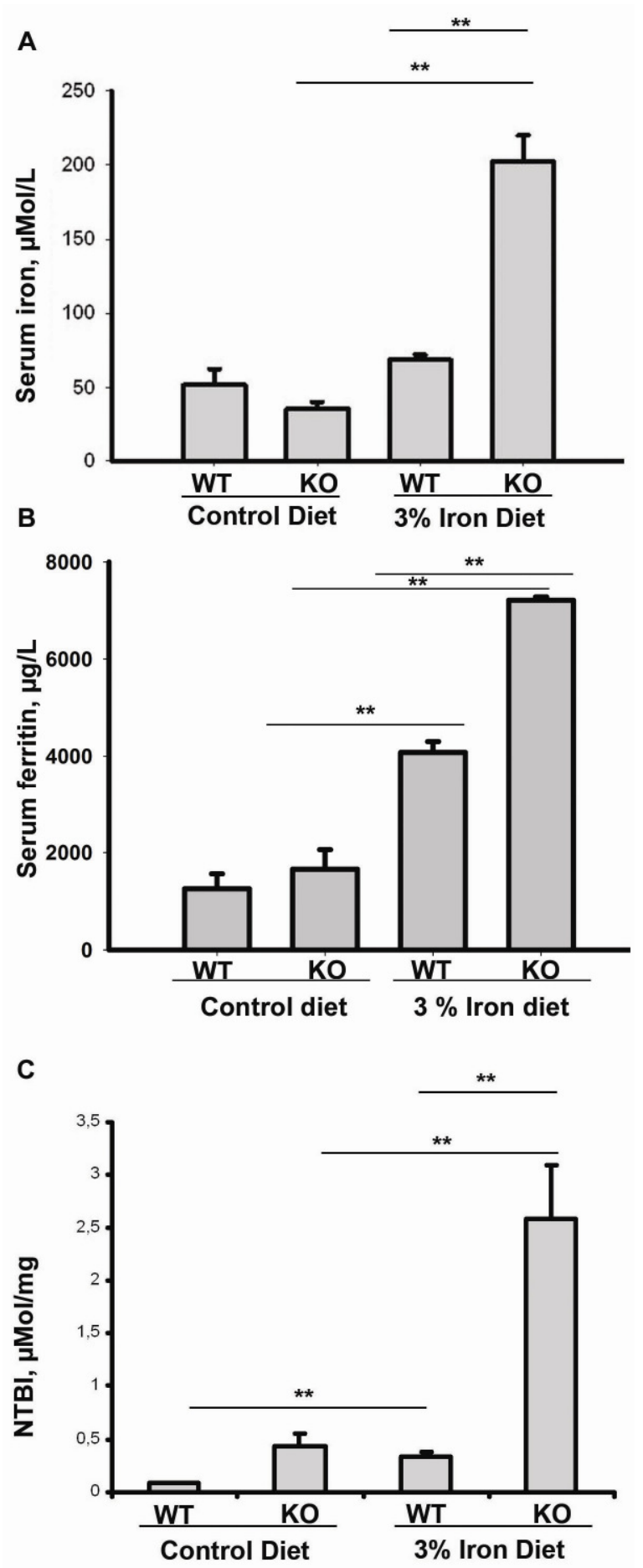

Figure 4.11. 12 months old hepcidin knockout mice kept on iron-rich diet develop massive iron overload. Serum iron (A), serum ferritin (B), and liver NTBI (C) levels were measured in hepcidin WT and KO mice fed with iron-rich and standard chow. Hepcidin KO mice on iron-rich diet showed a dramatic increase in all iron parameters. Result are presented as mean $\pm \mathrm{SD}$, double asterisk highlights $\mathrm{p}<0.05$. 


\subsection{Hepcidin knockout mice show dramatic deposition of iron in liver}

To evaluate iron distribution in 12 months old animals, Prussian Blue staining was performed (figure 4.12.A,C). Liver section from hepcidin WT mice on standard diet did not show any obvious iron accumulation (figure 4.12.A) and the liver non - heme iron content remained below $500 \mu \mathrm{g} / \mathrm{mg}$ of tissue. In contrast to that, hepcidin $\mathrm{KO}$ mice fed standard diet showed iron accumulation equally distributed throughout the liver lobes (Figure 4.12.B). Both genotypes subjected to iron-rich diet accumulated a significant amount of iron in their livers. As noted previously, iron accumulation in WT mice was seen in the periportal area (Figure 4.12.C), while iron accumulation was found in the whole liver in hepcidin $\mathrm{KO}$ mice, where a presence of big iron complexes was also noted (figure 4.12.D). Quantification of non - heme liver iron content revealed in all these experimental groups where iron leads being $\mathrm{KO}$ on iron-rich more than WT on iron-rich more than $\mathrm{KO}$ on control more than WT on control diet (Figure 4.12.E). Therefore, one can conclude that hepcidin $\mathrm{KO}$ mice on iron-rich diet displayed a dramatic iron accumulation in the liver. 

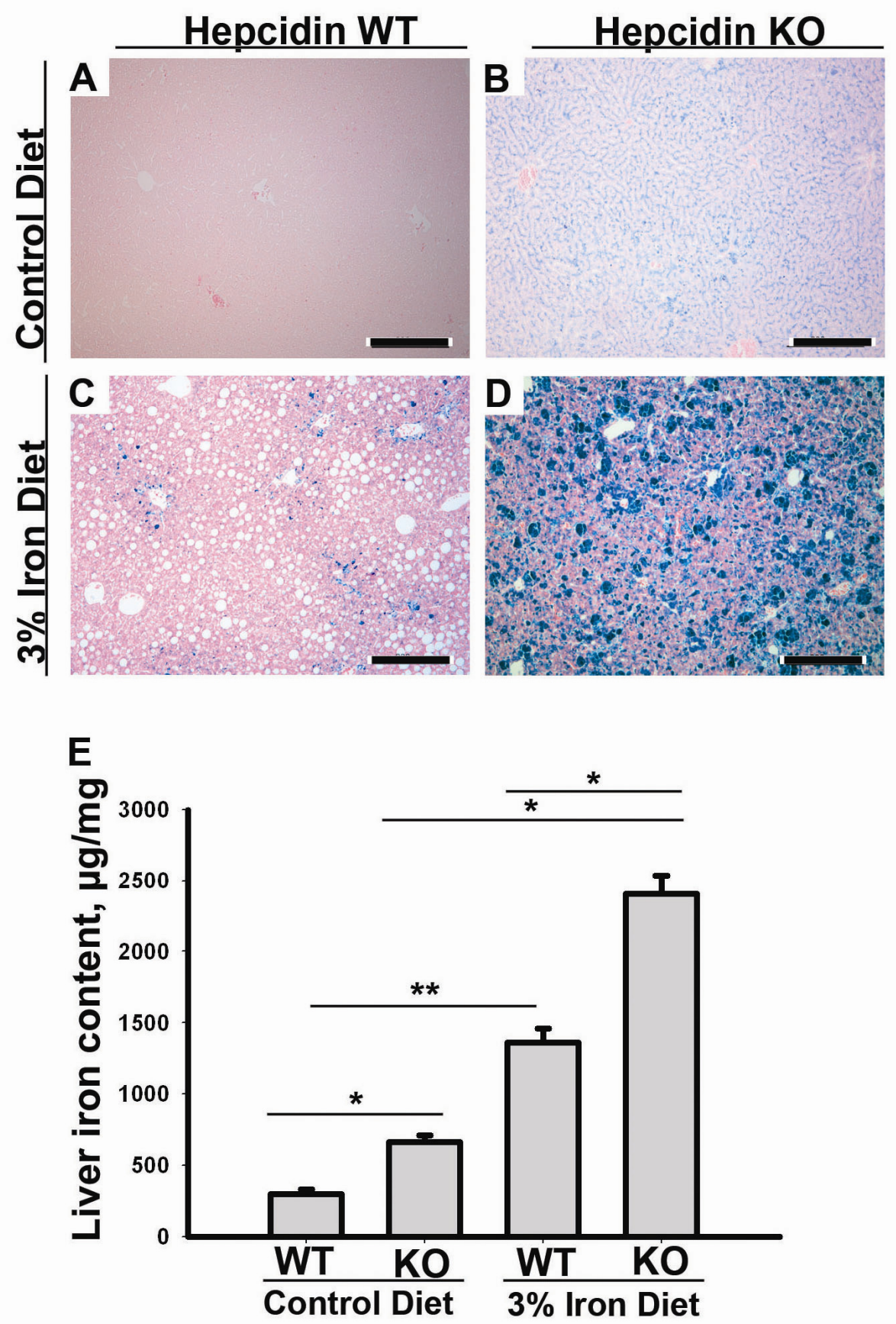

Figure 4.12. 12 months old hepcidin knockout mice fed iron-rich diet show dramatic iron accumulation in the liver. Prussian blue staining was done on liver slides of hepcidin WT (A, C) and KO mice $(B, D)$ fed normal chow $(A, B)$ or iron-rich diet $(C, D)$. Hepcidin KO mice fed iron-rich diet showed presence of large iron complexes in hepatocytes. Scale bar $200 \mu \mathrm{m}$. E) Biochemical determination of non heme liver iron content. Of notes, hepcidin $\mathrm{KO}$ mice on iron-rich diet showed dramatic elevation of liver iron content. Results are expressed as mean \pm SD $(n=5)$. Asterisk and double asterisk highlights $\mathrm{p}<0.05$ and $\mathrm{p}<$ 0.005 , respectively. 


\subsection{2 months old hepcidin knockout mice kept on iron - rich diet develop significant liver fibrosis}

It was questioned, whether the chronic liver injury seen in hepcidin KO mice on iron-rich diet leads to development of liver fibrosis. The mRNA levels of several fibrogenic markers, including collagen 1 (figure 4.13.G) and TGF $\beta$ (data not shown) were significantly increased in hepcidin $\mathrm{KO}$ mice on iron-rich diet. Moreover, collagen deposition was markedly increased in hepcidin $\mathrm{KO}$ mice on iron-rich diet as shown by Sirius Red staining and confirmed by its morphometric quantification (Figure 4.13.A-E). Finally, hydroxyproline content, which is used as biochemical marker of collagen deposition, was enhanced in hepcidin $\mathrm{KO}$ mice kept on iron-rich diet when compared to WT mice on the same feeding regime (Figure 4.13.F). These data demonstrate that massive iron overload seen in hepcidin KO mice on iron-rich diet is sufficient to induce the development of liver fibrosis. 

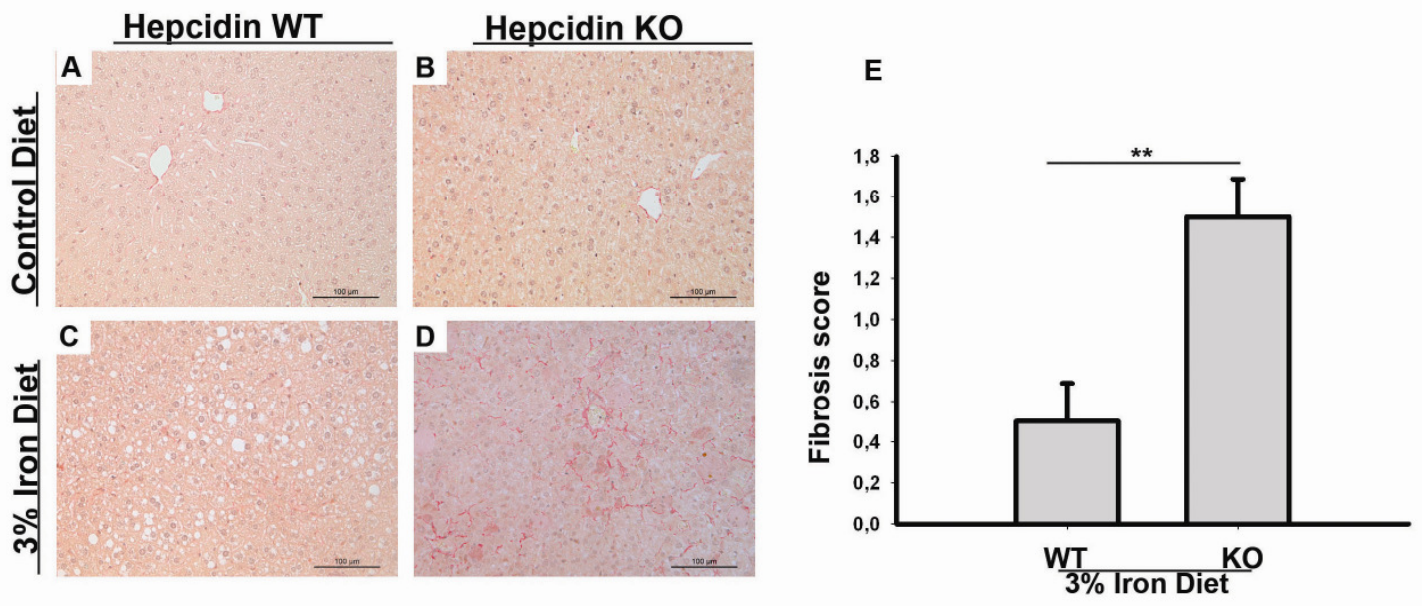

$\mathbf{F}$

G
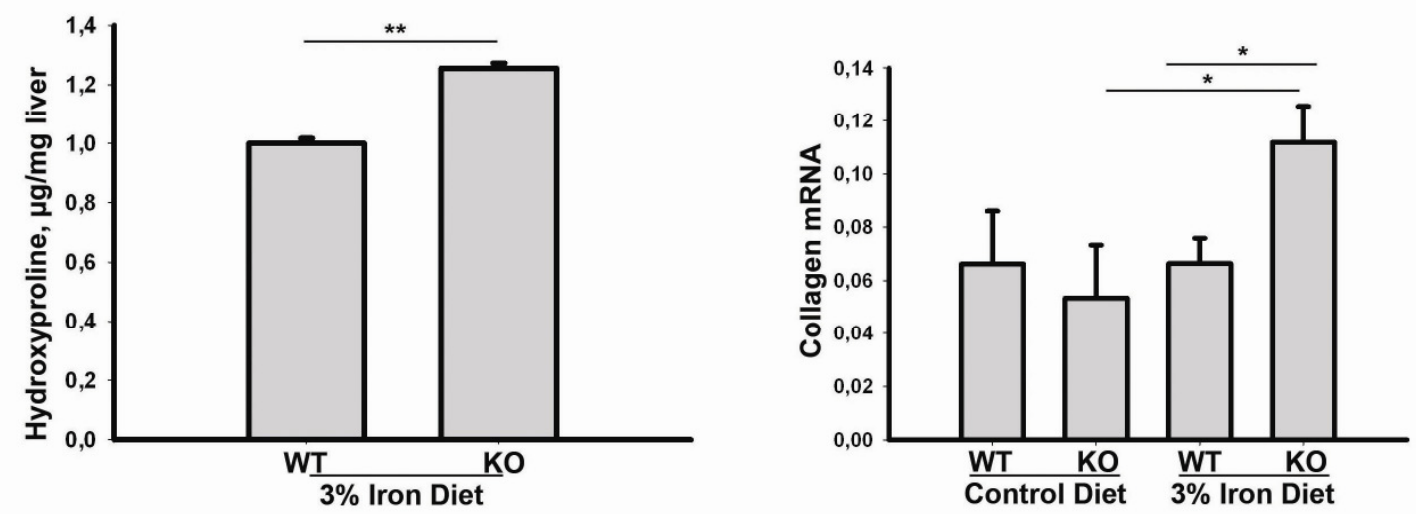

Figure 4.13. Hepcidin knockout mice develop significant liver fibrosis after feeding with iron - rich diet for 11 months. Sirius red staining was performed on liver slides of hepcidin WT (A, C) and KO (B, D) mice fed with control (A, B) and iron-rich diet (C, D). Scale bar $100 \mu \mathrm{m}$. Morphometric quantification of fibrosis deposits (E) seen in Sirius Red staining. Data are presented as mean \pm SD $(n=5)$ and double asterisk highlights $\mathrm{p}<0.05$. Hydroxyproline content $(\mathrm{F})$ was measured in livers of hepcidin KO and WT mice fed with iron-rich diet and shown as mean \pm SD $(n=5)$. Double asterisk highlights $p<0.05$. (G) The extent of collagen mRNA production was quantified using real time RT - PCR. Note that, hepcidin KO mice on ironrich diet show elevation of collagen mRNA production. Results are presented as mean \pm SD $(n=5)$ and asterisk highlights $\mathrm{p}<0.05$. 


\subsection{Hepcidin knockout mice show accumulation of iron in cytoplasm, mitochondria and lysosomes}

To better understand the impact of the described observations on intracellular iron distribution, subcellular fractionation in 6 months old animals was performed (Figure 4.14.). In mice fed control diet, iron was found mainly in cytoplasm, while lower levels were found in mitochondria, nucleus, and lysosomes and similar distribution was seen in WT mice on iron-rich diet. After iron-rich diet, the situation of iron deposition in the cell is changed. However, a profound change in distribution was seen in hepcidin $\mathrm{KO}$ mice subjected to iron-rich diet. These animals showed significant and dramatic increase of iron within lysosomes and smaller in mitochondria, but significant increase of iron content. Finally, a marked increase of iron in nuclear fraction was observed. However, given that no/minimal iron signal in the nucleus was observed in Prussian Blue staining, one can assume that the high nucleus levels are due to precipitation of iron during the fractionation process.

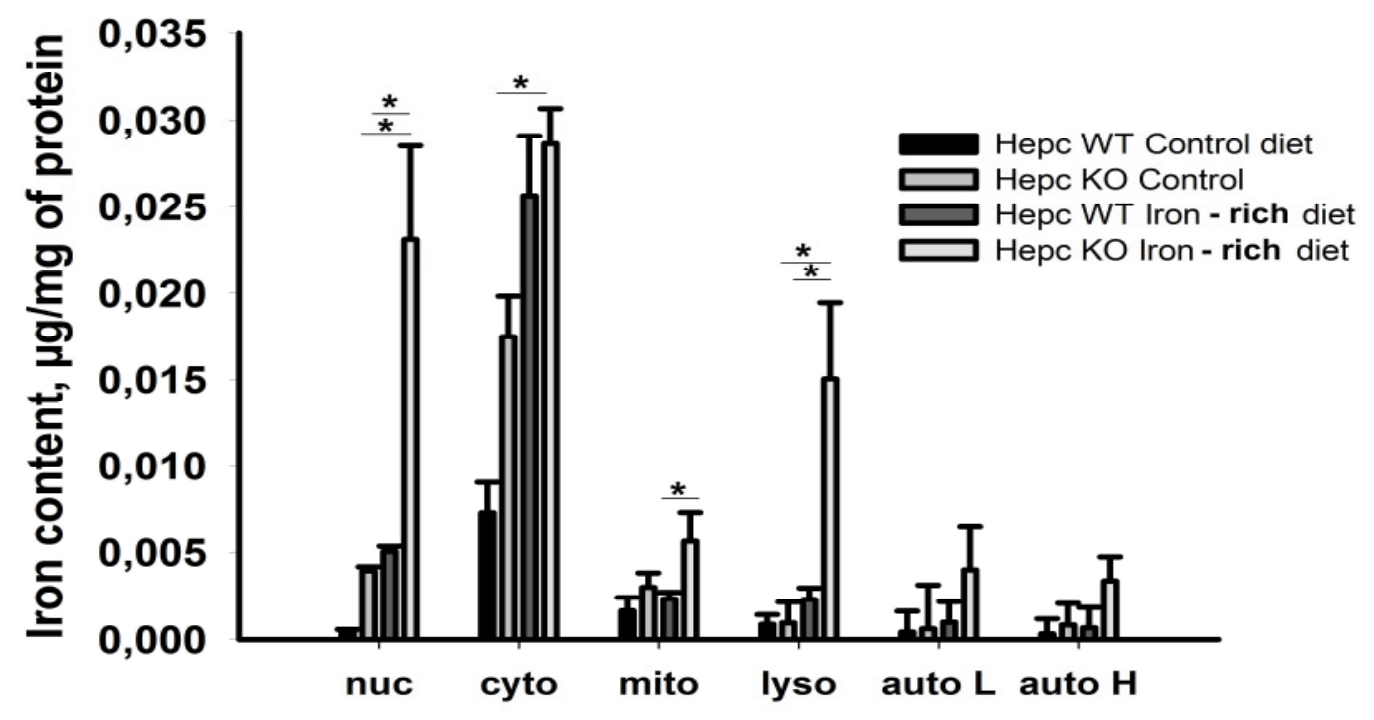

Figure 4.14. 6 months old hepcidin knockout mice kept on iron-rich diet show accumulation of iron in cytoplasm, mitochondria, and lysosomes. Subcellular fractionation of hepcidin WT and KO mice livers obtained from animals fed normal or iron-rich diet with subsequent determination of subcellular iron content. The data are presented as mean \pm SD $(n=3)$ and at least three mice were used per group and asterisk 
highlights $\mathrm{p}<0.05$. Nuc - nuclear fraction; cyto - cytoplasm; mito - mitochondria; lyso - lysosomes; auto L - autophagosomal light fraction; auto $\mathrm{H}$ - autophagosomal heavy fraction.

\subsection{6 months old hepcidin knockout mice fed iron-rich diet display large iron- containing complexes within lysosomes}

To better characterise the large iron complexes seen in hepcidin KO mice fed iron-rich diet, high resolution Electron Microscopy was performed (figure 4.15.A and C). Increased, distributed, presumably ferritin - bound iron signal was observed in hepcidin WT mice fed iron - rich diet (figure 4.15.C), while large intralysosomal iron - containing aggregates were seen in knockout mice on iron-rich chow (figure 4.15.A). The presence of hard metal was confirmed by subcellular fractionation. To further determine the composition of the aggregates, scanning electron microscopy (SEM) was performed, which revealed several peaks corresponding to iron complexes, which were seen in hepcidin $\mathrm{KO}$, but not WT mice subjected to iron-rich diet. 


\section{Hepcidin knockout}

A

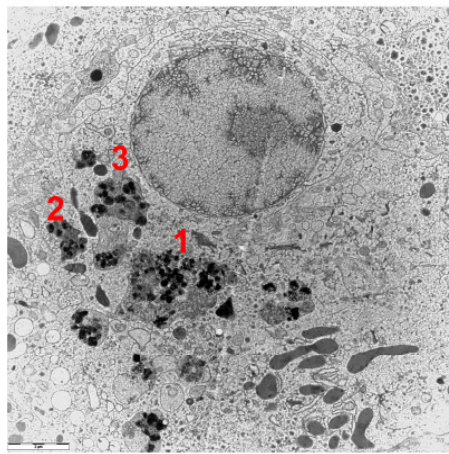

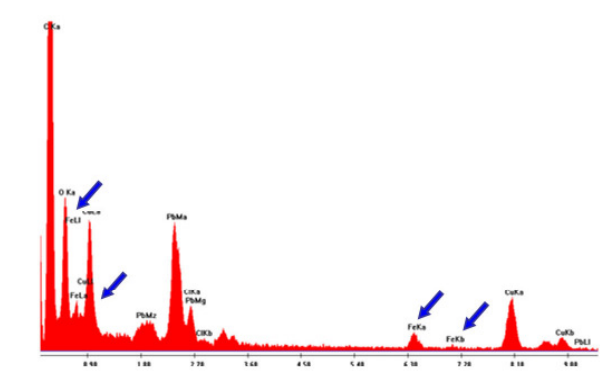

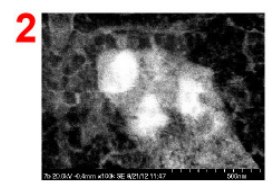

3

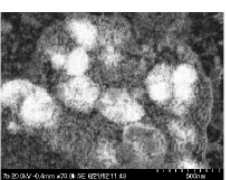

Hepcidin wild type

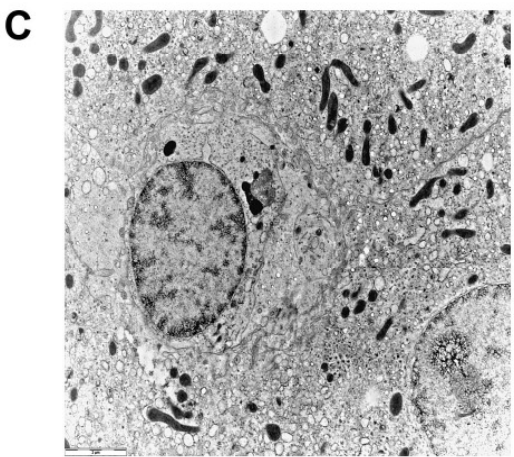

B

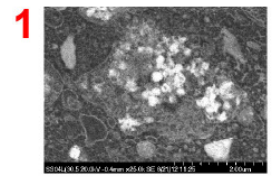

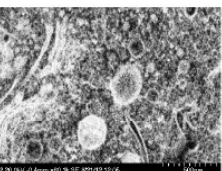

D

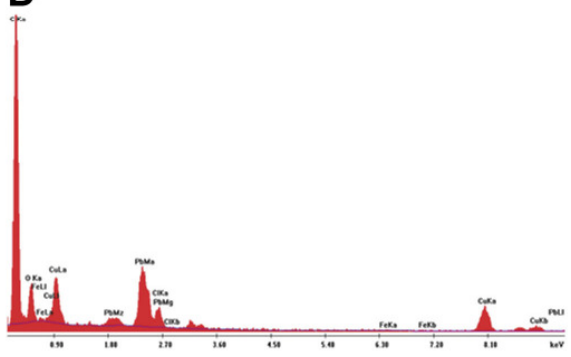

Figure 4.15. 6 months old hepcidin knockout mice fed iron-rich diet display large intralysosomal iron containing complexes. Electron microscopy was obtained from high pressure frozen liver tissues derived from hepcidin WT (A) and KO mice (B) fed iron-rich diet. Hepcidin KO, but not WT mice accumulate large iron - containing complexes in their lysosomes. Scale bar $2 \mu \mathrm{m}$. Electron spectrum from hepcidin KO (B) and WT mouse (D), with blue arrows showing iron. 


\subsection{Hepcidin knockout mice show downregulation of STEAP3 and DMT1}

To test, whether lysosomal iron accumulation in hepcidin $\mathrm{KO}$ mice is due to downregulation of genes responsible for iron transport, real time PCR from liver mRNA samples was performed. Hepcidin KO mice fed iron-rich diet for 5 months displayed downregulation of STEAP3 ferroreductase, which is responsible for iron reduction from FeIII to FeII and a diminished level of DMT1 - the known transporter of FeII from lysosomes to cytoplasm (figure $4.16 \mathrm{~A}, \mathrm{~B}$ ). On the other hand, hepcidin WT mice fed 5 months with iron-rich diet show normal STEAP3 and decreased DMT1 levels (figure 4.16 A,B). The molecular action of both genes is summarized in figure 4.16.C-E. 


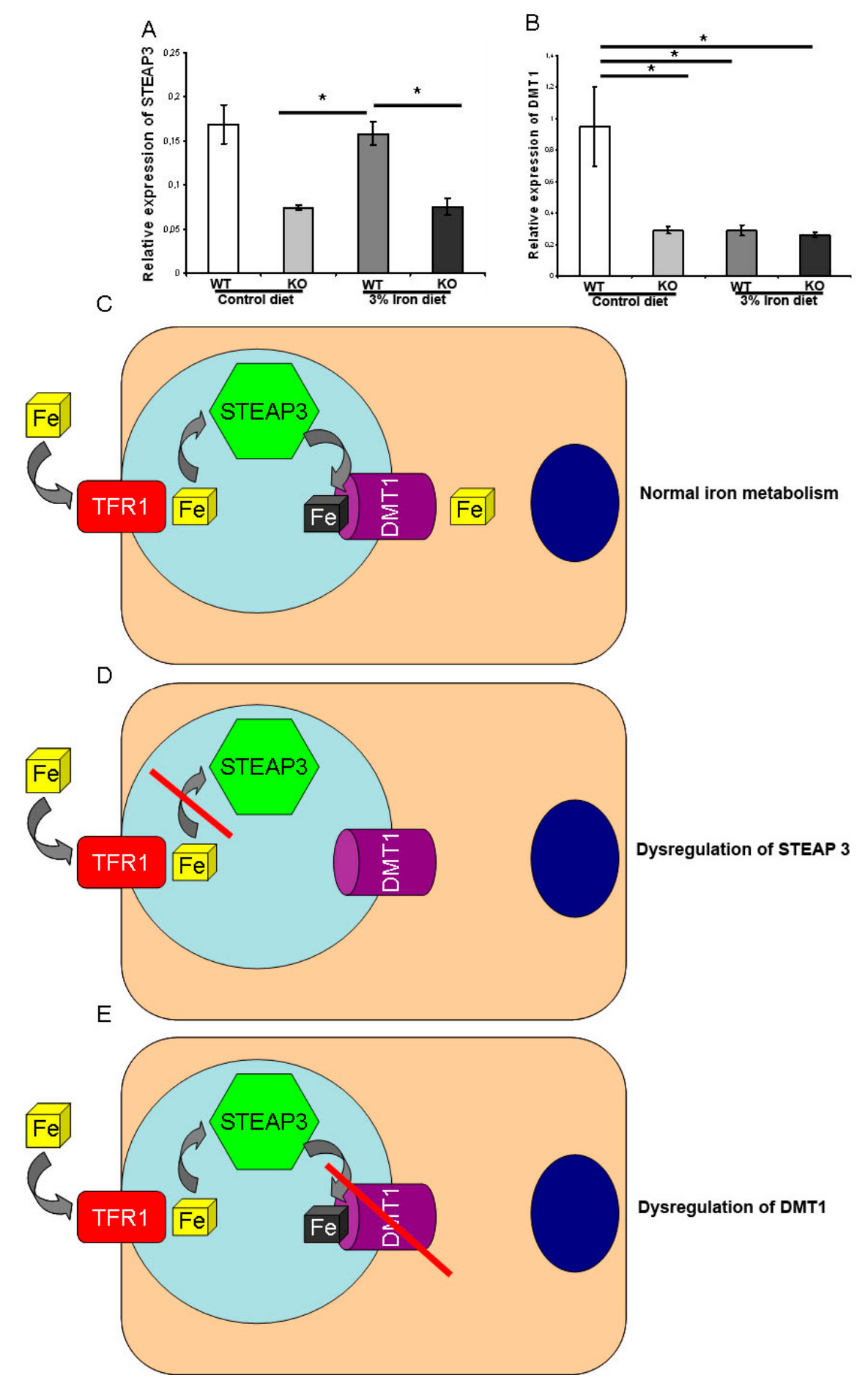

Figure 4.16. Hepcidin knockout mice show downregulation of STEAP3 and DMT1. (A, B) Real time PCR from liver RNA samples detects diminished DMT1 and STEAP3 levels in hepcidin KO mice fed with iron-rich food for 5 months. (C-E) Schematics highlight the iron trafficking under basal conditions, as well as in situations of diminished STEAP3/DMT1 production, which both may contribute to lysosomal iron accumulation. 


\subsection{Hepcidin knockout mice display elevated ferritin}

To test whether iron accumulation in hepcidin $\mathrm{KO}$ is counterbalanced by increased storage capacities immunoblotting was performed which detects the amount of the iron storing protein ferritin in total liver lysate as well as lysate from nuclear fractions. Both hepcidin KO mice on normal diet and WT animals fed iron-rich diet displayed elevated ferritin levels, but these levels were significantly lower than the ones observed in hepcidin KO mice fed iron-rich diet (Figure 4.17). Similar results, i.e. higher ferritin levels in hepcidin KO vs. WT mice kept on iron-rich diet, were seen in the nuclear fraction.

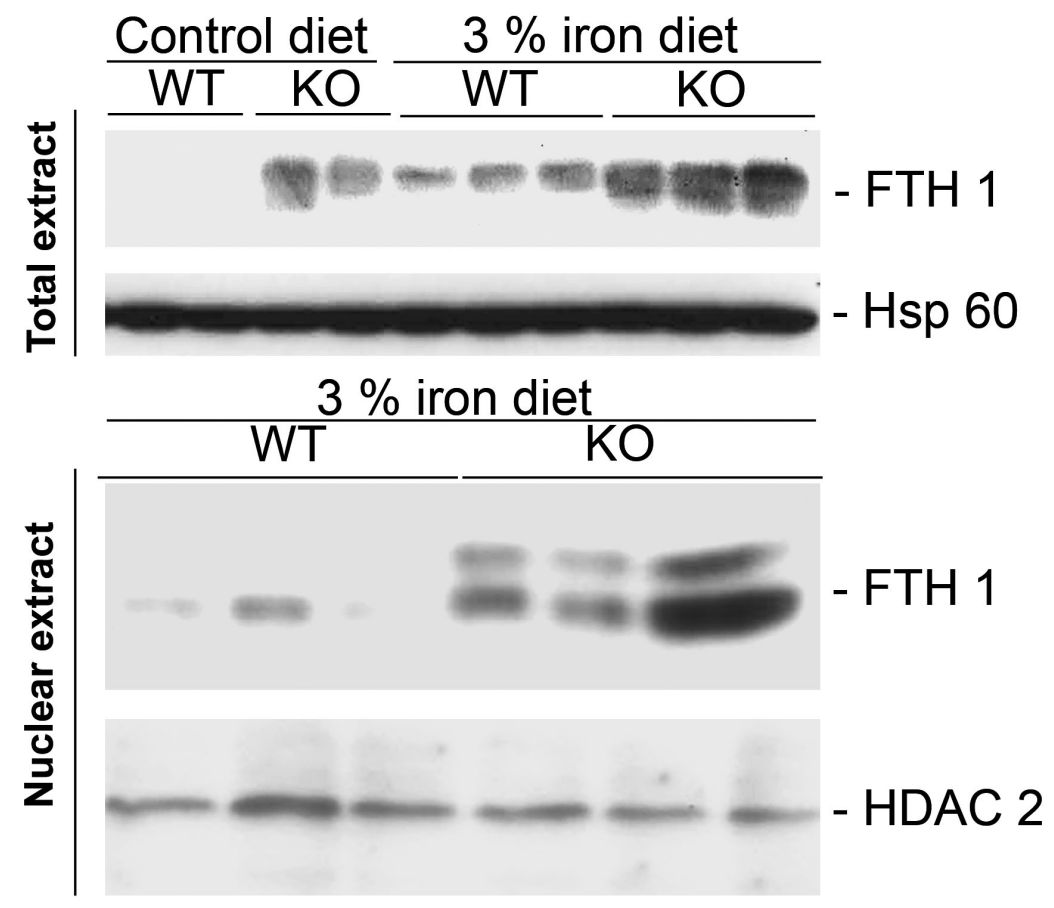

Figure 4.17. 6 months old hepcidin knockout mice show elevated ferritin levels. Ferritin immunoblot of total and nuclear protein extracts displayed elevated level of ferritin in hepcidin KO mice fed iron-rich diet. Hsp60 and HDAC2 were used as loading controls for total cell lysates and nuclear fractions, respectivetely. 


\subsection{Chronic iron overload leads to lysosomal damage in 6 months old hepcidin knockout mice fed iron - rich diet}

Hepcidin $\mathrm{KO}$ mice fed iron-rich diet displayed a marked increase in mitochondrial and lysosomal iron. To test the consequences of the iron accumulation in these organelles, it was analyzed whether this leads to the release of lysosomal or mitochondrial components into the cytoplasm (Figure 4.18.). Only minimal cytochrome C levels were detected in cytoplasm of iron-rich diet fed hepcidin KO and WT mice, suggesting no gross mitochondrial leakiness in these samples. On the other hand, cytoplasmatic levels were significantly elevated in hepcidin $\mathrm{KO}$ mice fed iron-rich diet pointing to a lysosomal damage in these animals.

\section{$3 \%$ iron diet}

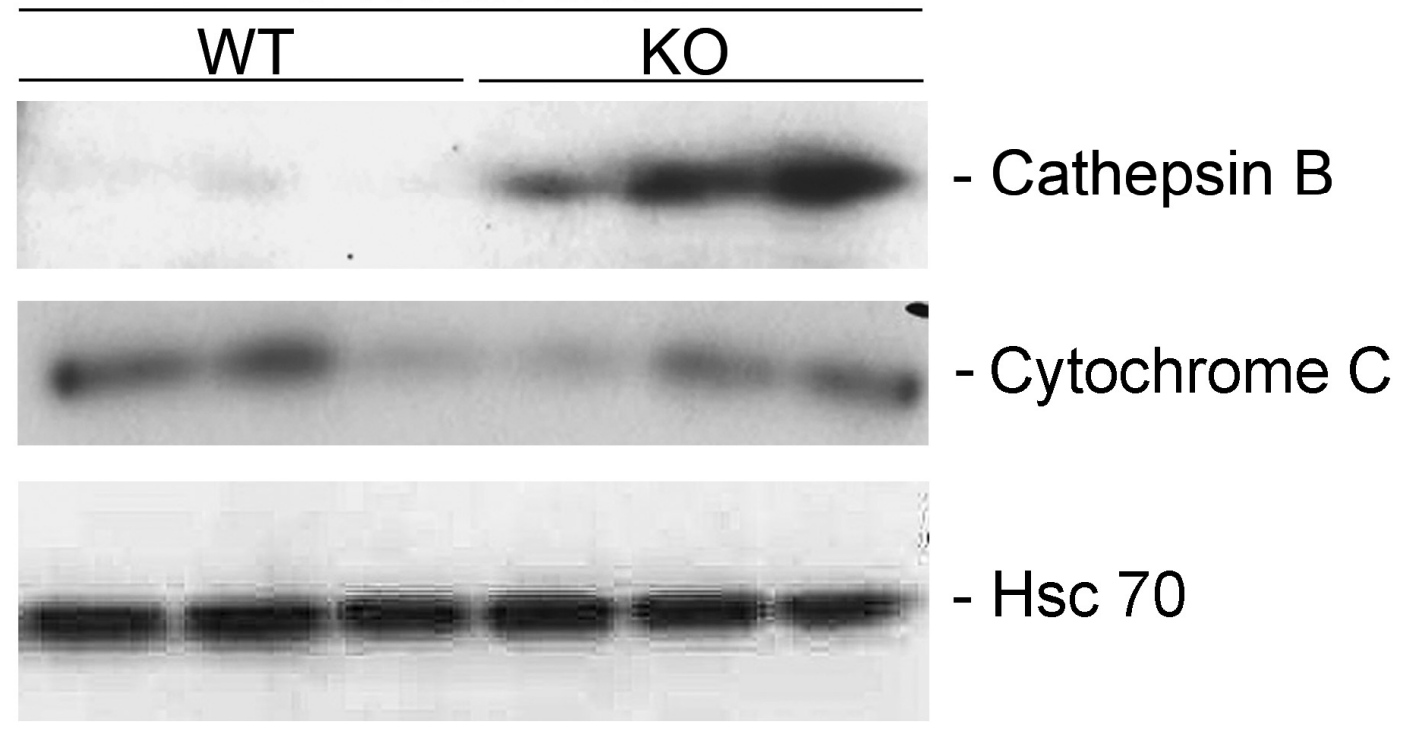

Figure 4.18. Chronic iron overload leads to lysosomal damage in 6 months old hepcidin knockout mice fed iron-rich diet. Liver cytoplasmatic extracts were subjected to antibody against Cathepsin B (top), Cytochrome C (middle), and Hsc 70 (bottom), which was used as a loading control. Note the occurrence of Cathepsin $\mathrm{B}$ in cytoplasm of iron-rich diet hepcidin $\mathrm{KO}$ mice pointing towards a lysosomal damage. 


\subsection{Hepcidin knockouts fed with iron-rich diet for 5 months show an altered autophagy activation}

Hepcidin KO mice fed iron - rich diet displayed a marked iron accumulation within lysosomes. To test, whether lysosomal iron accumulation affects the process of autophagy immunoblot analysis was performed on total liver lysates (figure 4.19 - top). Only hepcidin KO mice fed iron-rich diet showed increased LC3 II levels which point either to increased autophagic flux or an insufficient LC3 II clearance. The elevated p62 levels suggest that the not efficient autophagic response probably occurs in these animals (Figure 4.19 bottom).

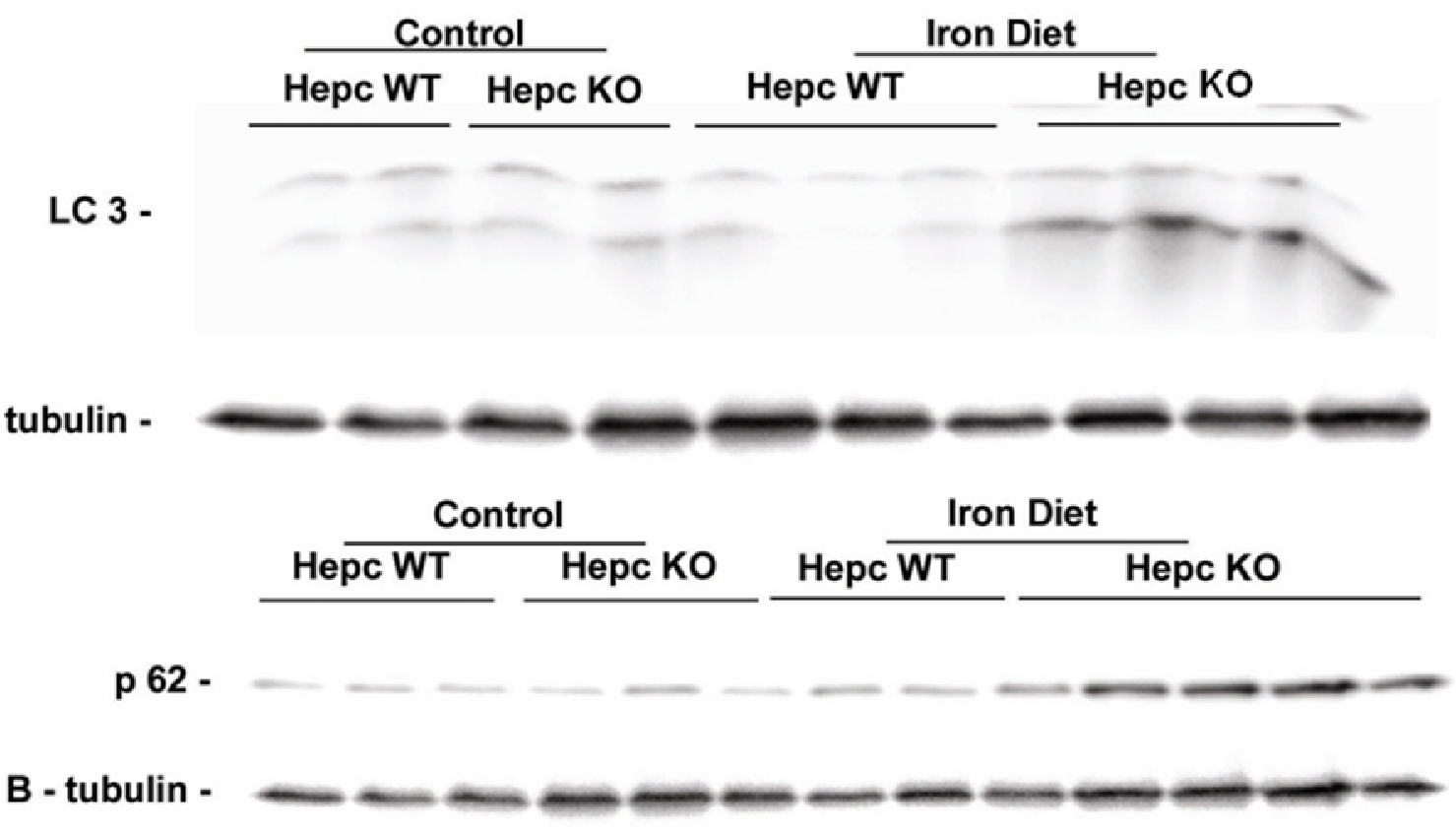

Figure 4.19. Hepcidin knockouts fed iron-rich diet for 6 months display an altered autophagic process. Liver total extracts were subjected to antibody against LC3 II (top), p 62 (bottom), and B-tubulin which was used as a loading control. Note the higher LC3 II and p62 levels, which suggest an activated, but not efficient autophagic response in hepcidin $\mathrm{KO}$ mice fed iron-rich diet. 


\subsection{Hepcidin knockout mice display an elevated oxidative DNA damage}

Finally, it was of interest whether iron accumulation seen in hepcidin KO mice on ironrich diet leads to oxidative DNA damage. Therefore, histological staining for DNA damage was performed, which was clearly present in hepcidin $\mathrm{KO}$ mice kept on iron-rich diet (Figure 4.20.A-D), while their nontransgenic littermates did not show oxidative DNA damage. These data demonstrate that massive iron overload seen in hepcidin $\mathrm{KO}$ mice on iron-rich diet is sufficient to induce oxidative DNA damage.

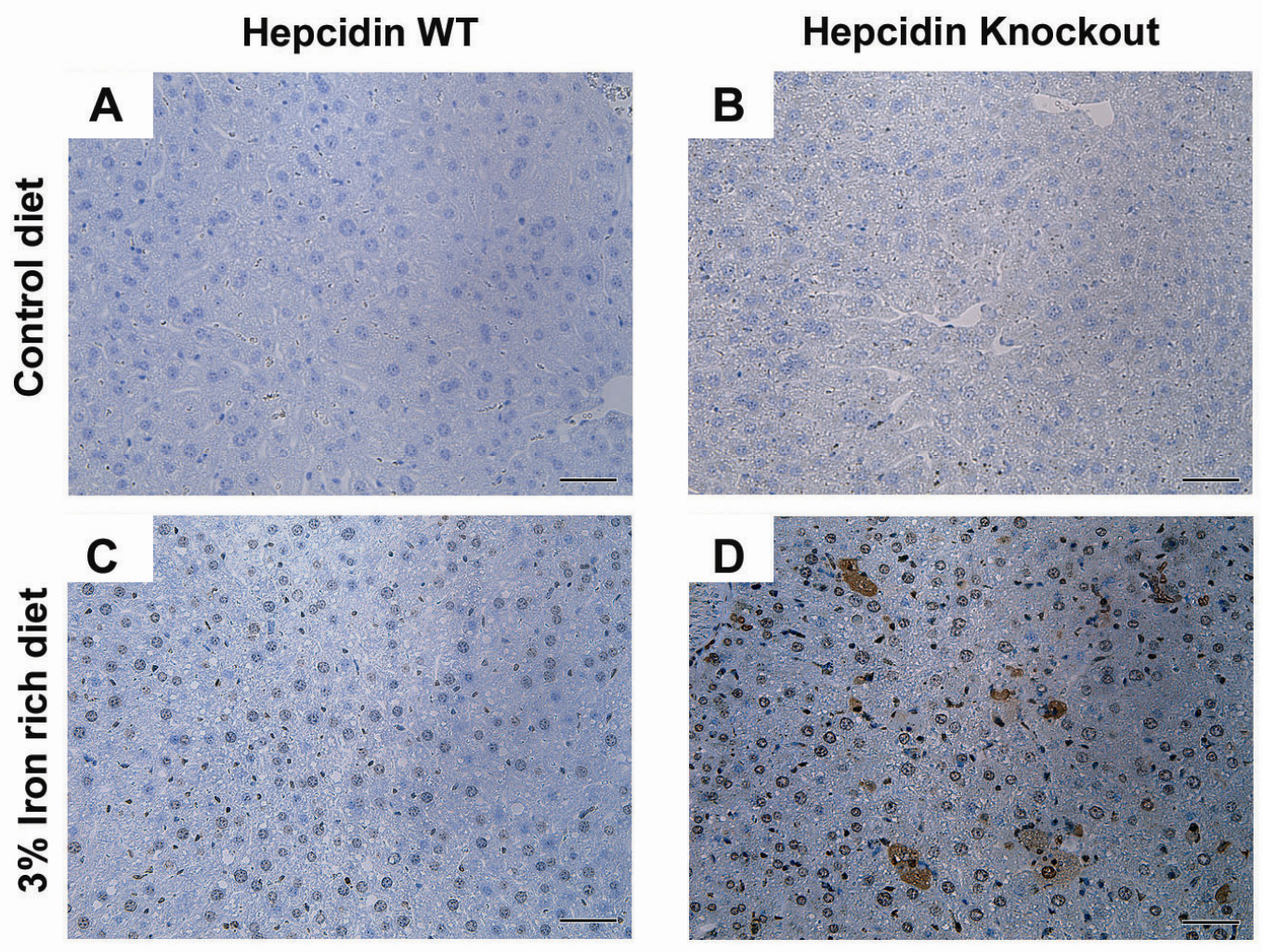

Figure 4.20. Hepcidin knockout mice display signs of oxidative DNA damage. Staining of liver tissues (A

- D) with 'In situ Cell Death Detection Kit, POD' was performed to detect the signs of oxidative DNA damage. 6 months old hepcidin WT (A,C) and KO mice (B,D) fed normal diet (A,B) and iron-rich chow (C,D) were analyzed. Note the presence of oxidative DNA damage in hepcidin KO mice kept on iron-rich diet. Scale bar $50 \mu \mathrm{m}$. 


\section{Discussion}

In this study, hepcidin knockout mice were evaluated as a model of iron-overload associated liver injury. As was also reported previously [54], hepcidin knockout mice developed a spontaneous liver iron overload, which was even more pronounced when they were fed with iron-rich diet. In the latter group, a hepatic iron-content of approximately $45 \mu \mathrm{mol} / \mathrm{g}$ tissue was observed, which lies well above concentration found in most dietaryinduced models of iron-overload. For example, values up to $30 \mu \mathrm{mol} / \mathrm{g}$ were seen in TfR2/HFE double knockout mice, hemojuvelin KO, BMP6-KO or HFE knockout mice while the HFE C282Y knock-in animals, which represent the animal counterpart of the most common hemochromatosis form, displayed even lower hepatic iron contents $[121,122,123]$. The high amount of iron accumulation in hepcidin knockout animals is even more remarkable given that C57BL/6 animals represent a strain which is relatively resistant to iron-overload [119]. On the other hand, comparable or even higher hepatic iron levels were reported in animals fed with ferrocene or receiving intraperitoneal supplementation with iron dextran or ferric ammonium citrate. However, these models are of limited value since they are achieved by non-physiological iron uptake mechanisms and do not mimic the chronic, slow increase of iron levels seen in hemochromatosis subjects $[124,125,126,127,128,129]$.

Despite the massive iron overload observed in hepcidin knockout mice, the iron accumulation is comparable or even lower than the one observed in human $\mathrm{HH}$ subjects [130,131]. For example, HH patients can accumulate more than $1 \mathrm{mmol}$ iron/g liver tissue $[132,133]$, while in healthy subjects hepatic iron content ranges from 10 to $36 \mu \mathrm{mol} / \mathrm{L}$ $[132,134,135]$. Although the association between iron overload and liver disease development is imperfect, Adams et al showed that HH subject with hepatic iron content more than $1 \mathrm{mmol} / \mathrm{g}$ are at high risk for development of liver cirrhosis [136]. 
As a marker of systemic iron overload, hepcidin knockout mice fed with iron-rich diet displayed not only elevated hepatic iron content but also highly increased serum ferritin levels of approximately $5000 \mu \mathrm{g} / \mathrm{L}$. Serum ferritin levels observed in hepcidin knockout mice are comparable with data seen in untreated $\mathrm{HH}$ patients [137]. Measurement of serum ferritin in HFE patients is of clinical importance since HH patients with serum ferritin $<1000 \mu \mathrm{g} / \mathrm{L}$ are unlikely to display advanced liver fibrosis while ferritin values $>1000 \mu \mathrm{g} / \mathrm{L}$ confer more than threefold higher risk for development of advanced fibrosis $[137,138,139,140,141,142]$.

In addition, hepcidin knockouts fed iron-rich diet showed increased levels of hepatic iron and serum NTBI, i.e. approximately $1.2 \mu \mathrm{mol} / \mathrm{mg}$ and $10 \mu \mathrm{mol} / \mathrm{L}$ respectively. Therefore, observed NTBI values in this study are similar to the serum levels seen in $\mathrm{HH}$ subjects (mean serum NTBI $=11.9 \mu \mathrm{mol} / \mathrm{L}$ ) [143]. On the other hand, values observed in hepcidin knockout mice fed iron-rich diet are higher than values seen in other animal models of iron overload, such as HFE KO, TFR2 KO and $\mathrm{HFE}^{-/} / \mathrm{TFR}^{\mathrm{mut}}$ [144]. For example, HFE/TFR2 double knockout mice displayed serum NTBI level of approximately $9 \mu \mathrm{M}$, while HFE and TFR2 knockout mice showed even lower serum NTBI of approximately 3-4 $\mu \mathrm{M}$ [144]. These differences might be particularly important since NTBIs represent the primary toxic iron species [82] and their levels correlate with the extent of liver damage. For instance, McNamara et al 1999 showed that HH patients with NTBI $>2 \mu \mathrm{mol} / \mathrm{L}$ displayed an inflammatory liver disease [145]. In conclusion, the particularly high extent of iron accumulation in hepcidin knockout mice which is evidenced by high NTBIs, ferritin, and liver iron levels likely contributes to the development of liver injury in hepcidin knockout mouse model as it has been observed in HH subjects [144,145].

With respect to the histological signs of liver injury, hepcidin KO mice fed with iron-rich, but not normal diet displayed mild liver inflammation, which was also observed in $\mathrm{HFE}^{-/-}$ /TFR2 ${ }^{\text {mut }}$ mice [144]. On the other hand, no apparent inflammation was seen in HFE KO 
mice and TFR2 ${ }^{\text {mut }}$ mice fed iron-rich diet [144]. Interestingly, both mouse lines showed a predominantly mononuclear infiltration, which is reminiscent of $\mathrm{HH}$ subjects, who present with a similar picture and in whom the presence of inflammation associates with liver fibrosis development [146,147]. While the exact reasons for the predominance of mononuclear infiltration in iron overload syndromes remain unknown, it is well in line with the important role of macrophages in iron metabolism [101,148,149].

In terms of liver injury, moderately increased liver injury marker ALT (of approximately $361 \mathrm{u} / \mathrm{L}$ ) was observed in hepcidin $\mathrm{KO}$ mice fed iron-rich diet and this level was well above those reported in comparable animal models, such as HFE KO, TFR2 KO and $\mathrm{HFE}^{-}$ ${ }^{\text {I- } / T F R 2}{ }^{\text {mut }}$ mice [144] or in HH subjects $[150,151]$. Other liver injury markers such as AST and AP were also higher in hepcidin KOs fed iron-rich diet (the value of approximately $734 \mathrm{u} / \mathrm{L}$ and $362 \mathrm{u} / \mathrm{L}$ respectively) compared to $\mathrm{HH}$ subjects $[151,152]$. However, this is not surprising since it has been shown previously that mice often require a more active disease to develop significant liver alterations within their relatively short life span.

In hepcidin KO mice fed iron-rich diet, elevated apoptosis levels were observed (assessed by D237 tissue labeling and histological scoring). It has been shown previously that elevated apoptosis levels can lead to the development of chronic injury and even to liver fibrosis [153] and increased apoptosis was observed in other animal models of iron overload [153,154]. Furthermore, increased hepatic apoptosis is seen in HH subjects $[155,156]$. Of note, a direct correlation between liver iron amount and the extent of apoptosis was evident both in hepcidin knockout mice and in HH subjects ([155] and data not shown). Moreover, the patterns of apoptosis and iron depositions overlap which further strengthens the mechanistic link between both processes [155].

In addition to liver inflammation and hepatocellular apoptosis, hepcidin $\mathrm{KO}$ mice as well as $\mathrm{HFE}^{-/} / \mathrm{TFR} 2^{\text {mut }}$ mice showed liver fibrosis development [144]. However, both animal models displayed a chicken-wire type of fibrosis (perivenular and pericellular fibrosis) 
which is characteristic for humans with alcoholic or non-alcoholic steatohepatitis but rarely occurs in $\mathrm{HH}[144,155,157]$. The reason for this type of fibrosis might be the fact that hepcidin knockout mice (unlike humans) exhibit an ubiquitous iron overload with an ubiquitous liver injury while the iron accumulation and liver injury is observed predominantly in periportal area in humans $[50,155]$. Moreover, the higher activity of liver disease in mice versus humans might be responsible for this observation.

Given that the association between the extent of iron overload and development of liver injury is imperfect, one can hypothesize that an improper iron distribution affects the development of liver disease. In this respect, marked iron overload was detected in lysosomes of hepcidin $\mathrm{KO}$ mice fed iron-rich diet compared to all other treatment groups. Obviously, a loss of hepcidin alone was not sufficient to induce this accumulation, therefore, it was concluded that it is a consequence of an extreme iron overload rather than a genetic defect per se. What might be the mechanisms underlying this observation? In hepatocytes, transferrin receptor 1 represents the major way of intracellular iron uptake and after endocytosis of the iron-receptor complex, it brings iron into lysosomes $[91,158]$. After release from the transferrin complex, iron is reduced via STEAP3 in order to be exported to cytoplasm via DMT1 [91]. While the TfR1 levels did not change (data not shown) in hepcidin knockout mice, both STEAP3 and DMT1 levels were lower in hepcidin KO mice fed iron-rich diet suggesting that a disturbed processing and release of iron might be responsible for the observed overload. Additional studies are needed to find out whether the release of iron from transferrin complex, which represents a highly regulated process requiring acidification of lysosomes among others might also be affected [91]. Finally, iron is taken up from cytoplasm into lysosomes to remove redox-active iron [159]. In this respect, signs of elevated autophagy which likely contribute to the intralysosomal iron burden were found [160]. 
The lysosomal iron overload observed in hepcidin knockout mice is well in line with other animal models such as the feeding with ferrocene or iron carbonyl which also displayed lysosomal iron accumulation [159,161,162]. Furthermore, lysosomal iron overload of hepatocytes is commonly seen in $\mathrm{HH}$ patients $[163,164]$. Consequently, Peters and colleagues proposed that iron overload due to either primary $\mathrm{HH}$ or transfusional siderosis represents a form of acquired lysosomal storage disease [165].

On the other hand, hepcidin knockout mice fed iron-rich diet showed only minor changes in mitochondrial and cytoplasmatic iron content and similarly, mitochondrial iron accumulation is uncommon in $\mathrm{HH}$ [95] as well as in animals fed with ferrocene or ironcarbonyl containing diet $[159,162]$. These findings are not surprising since mitochondrial iron trafficking seems to be controlled independently on systemic iron levels and mitochondrial iron overload develops primarily due to defect in genes responsible for heme biosynthesis, iron-sulfur clusters biogenesis or mitochondrial iron transport $[2,166,167]$. Several mechanisms may account for the steady hepatic iron levels in cytoplasm. For example, ferroportin constitutes a potent cytoplasmatic iron exporter which is expressed in hepatocytes and becomes increasingly active in the absence of hepcidin [23]. Autophagy process may also counteract the iron accumulation in cytoplasm $[160,168]$ and this study indicated that hepcidin knockout mice displayed signs of activated autophagy (i.e. LC3 II activation and p62 accumulation).

Besides the lysosomal iron overload, hepcidin $\mathrm{KO}$ mice also displayed lysosomal damage as evidenced by the release of cathepsin B into the cytoplasm as well as intralysosomal accumulation of indigestible autofluorescent material (data not shown). Similar events were shown in ferrocene and iron-carbonyl fed animals $[159,162]$ as well as in HH patients [95]. These findings are not surprising, since lysosomes often contain iron in the form of the reactive Fe (II), which can catalyze the Fenton reaction and thereby lead to hydroxyl radical formation [160]. These hydroxyl radicals may then attack biomolecules and 
interfere with their proper degradation [98]. The pronounced oxidative injury present in iron-overloaded lysosomes may in turn cause lysosomal membrane damage and release of cathepsins [160]. It has been shown previously that cathepsin release into cytoplasm can activate caspases and may therefore account for the increased apoptosis levels observed in hepcidin knockout mice $[169,170]$.

In summary, these data suggest that hepcidin knockout mice develop chronic liver injury and liver fibrosis as a consequence of lysosomal iron overload and consequent lysosomal damage. In this respect, several other studies as well as human data showed that lysosomal damage plays an important role in development of chronic liver disease. To that end, Canbay et al reported that inactivation of cathepsin B reduced hepatic inflammation and fibrogenesis in an experimental model of cholestatic liver disease [171]. Further studies are needed to find out whether the described liver phenotype is due to hepatocellular cathepsins or whether the cathepsin expression in stellate cells, which has been shown to increase during hepatic injury, plays the pivotal role in this process [172].

Another evidence, that lysosomal injury directly contributes to development of liver disease comes from lysosomal storage disorders. They constitute a group of approximately 50 rare inherited metabolic disorders leading to lysosomal dysfunction and are typically caused by mutations in a single lysosomal enzyme such as alpha- and betta-galactosidases, alpha- glucosidase and aspartylglucosaminidase [173]. Lysosomal storage diseases typically lead to neurological abnormalities, developmental delay, but also to enlarged livers, pulmonary and cardiac as well as kidney, and skeletal phenotype [173]. Among them, Niemann-Pick type $\mathrm{C}$ disease represents a best characterized lysosomal storage disorder resulting in a marked liver phenotype [173]. It is caused by mutations in NPC1 or NPC2, which participate in trafficking of proteins from lysosomes [174] and leads to accumulation of several molecules such as cholesterol, glycosphingolipids, and sphingosine within lysosomes [174]. Interestingly, similar to the hepcidin knockout mice, 
an increased activation of the innate immune system represents the major feature of liver phenotype while elevated apoptosis and oxidative stress are observed later on $[175,176,177]$.

In conclusion, hepcidin knockout mice constitute a convenient model of human iron overload-associated liver disease and further support the importance of lysosomes in this process. This is well in line with human observations, which detected obvious lysosomal alterations in close proximity to the fibrotic lesions in $\mathrm{HH}$ subjects while there are no or only minimal mitochondrial abnormalities $[163,178]$. On the other hand, further studies are needed to delineate the precise relationship between the lysosomal iron overload and lysosomal dysfunction on one side and the hepatocellular apoptosis, hepatic inflammation, and liver fibrosis development on the other. In fact, there may not be only a single mechanism going on but rather a myriad of processes contributing to the observed phenotype. For example, leakage of lysosomal enzymes into the cytoplasm may lead to hepatocellular apoptosis [160] and the subsequent engulfment of apoptotic bodies may result both, in macrophage activation and a direct activation of hepatic stellate cells [156]. Furthermore, hepatocellular iron overload can also stimulate stellate cells in a paracrine way [179]. While the current evidence indicates that loss of hepcidin results in a diminished macrophage iron content, further studies are on the way to determine the macrophage and hepatic stellate cell iron content in hepcidin knockout mice fed iron-rich diet. These studies will clarify whether the observed liver phenotype is a sole consequence of hepatocellular iron overload or whether loss of hepcidin may also induce iron overload in other cell types. Last but not least, elevated serum iron may also contribute to the observed phenotype via activation of endothelial cells [180]. 


\section{Summary}

Hepcidin is the central regulatory hormone of iron metabolism. Disrupted hepcidin signalling is seen in multiple genetic disorders termed as hereditary hemochromatosis $(\mathrm{HH})$ where it leads to hepatic iron overload. Acquired iron overload is observed in several chronic diseases such as hepatitis $\mathrm{C}$ or alcoholic liver disease and seems to promote disease progression. While the association between iron overload and development of end-stage liver disease is well established, the precise underlying mechanisms remain to be defined. Although there is a number of animal models that mimic the genetic defects found in humans, none of them replicates the iron overload-associated liver disease. To develop such a model, we analyzed hepcidin knockout (KO) and wild type (WT) mice were fed with iron-rich diet for 5 or 11 months and compared them to age matched mice kept on standard chow. Harvested livers and serum samples were used for evaluation of liver injury and fibrosis. To determine the iron localization, a subcellular fractionation and electron microscopy was performed.

Hepcidin KOs kept on standard diet developed spontaneous hepatic iron overload, which was even more pronounced in KOs fed iron-rich chow (KO:2543 \pm 114 vs. WT: $1493 \pm 136$ $\mathrm{p}<0,005)$ who reached levels similar to the ones observed in $\mathrm{HH}$ patients. Elevated serum liver enzymes (AST: KO 261 \pm 15 , WT 142 $\pm 34 \mathrm{p}<0,05$ ), serum iron levels, mild hepatocellular inflammation (predominantly mononuclear infiltration) and apoptosis were observed in hepcidin KOs fed iron-rich diet. After 11 months of iron-rich chow, hepcidin KOs developed moderate liver fibrosis as demonstrated via Sirius red staining and increased hydroxyproline levels. The liver injury was accompanied by a marked lysosomal iron overload and lysosomal fragility with release of cathepsins (e.g. Cathepsin B) into the cytoplasm. No major differences were seen in mitochondrial morphology or injury markers. As a potential mechanism leading to lysosomal iron overload, the expression of 
DMT1 and STEAP3, i.e. the molecules needed for lysosomal iron export, was greatly reduced. Increased LC3-II and p62 levels pointed towards an activated autophagy which likely contributes to the lysosomal iron overload. On the other hand, large indigestible iron complexes were found in hepcidin knockout mice fed iron-rich diet thereby suggesting a defect in protein degradation as it is observed in lysosomal storage diseases.

In conclusion, hepcidin $\mathrm{KO}$ mice represent an attractive animal model which mimics both iron overload and associated liver injury observed in humans with HH. Therefore hepcidin knockout mice constitute an important tool to study the mechanism of iron overload-related liver diseases and implicate lysosomal injury as a crucial event in iron hepatotoxicity. 


\section{References}

1. Evstatiev R, Gasche C (2012) Iron sensing and signalling. Gut 61: 933-952.

2. Sheftel A, Stehling O, Lill R (2010) Iron-sulfur proteins in health and disease. Trends in Endocrinology \&amp; Metabolism 21: 302-314.

3. Lill R (2009) Function and biogenesis of iron-sulphur proteins. Nature 460: 831-838.

4. Khan AA, Quigley JG (2011) Control of intracellular heme levels: Heme transporters and heme oxygenases. Biochimica et Biophysica Acta (BBA) - Molecular Cell Research 1813: 668-682.

5. Anderson GJ, Frazer DM (2005) Hepatic Iron Metabolism. Semin Liver Dis 25: 420432.

6. Pantopoulos K, Porwal SK, Tartakoff A, Devireddy L (2012) Mechanisms of Mammalian Iron Homeostasis. Biochemistry.

7. Zhang A-S, Enns CA (2009) Iron Homeostasis: Recently Identified Proteins Provide Insight into Novel Control Mechanisms. Journal of Biological Chemistry 284: 711715.

8. Ganz T (2008) Iron Homeostasis: Fitting the Puzzle Pieces Together. Cell Metabolism 7: 288-290.

9. Krause A, Neitz S, Mägert H-J, Schulz A, Forssmann W-G, et al. (2000) LEAP-1, a novel highly disulfide-bonded human peptide, exhibits antimicrobial activity1 1 The nucleotide sequence data reported in this paper have been submitted to the GenBank/EBI Data Bank with accession number AJ277280. Scanning of this sequence against the data base resulted in the identification of related sequences with the accession numbers AD000684 and P81172. FEBS Letters 480: 147-150.

10. Ganz T (2003) Hepcidin, a key regulator of iron metabolism and mediator of anemia of inflammation. Blood 102: 783-788.

11. Park CH, Valore EV, Waring AJ, Ganz T (2001) Hepcidin, a Urinary Antimicrobial Peptide Synthesized in the Liver. Journal of Biological Chemistry 276: 7806-7810.

12. Nemeth E, Tuttle MS, Powelson J, Vaughn MB, Donovan A, et al. (2004) Hepcidin Regulates Cellular Iron Efflux by Binding to Ferroportin and Inducing Its Internalization. Science 306: 2090-2093.

13. Ganz T (2011) Hepcidin and iron regulation, 10 years later. Blood 117: 4425-4433.

14. Deugnier YY (2010) The iron driven pathway of hepcidin synthesis. Gastroenterol Clin Biol 34: 351-354. 
15. Ganz T, Nemeth E (2011) Hepcidin and Disorders of Iron Metabolism Annual Review of Medicine 62: 347-360.

16. Camaschella C, Silvestri L (2011) Molecular Mechanisms Regulating Hepcidin Revealed by Hepcidin Disorders. The Scientific World Journal 11: 1357-1366.

17. Ganz T, Nemeth E (2012) Hepcidin and iron homeostasis. Biochimica et Biophysica Acta (BBA) - Molecular Cell Research 1823: 1434-1443.

18. Prentice AM, Doherty CP, Abrams SA, Cox SE, Atkinson SH, et al. (2012) Hepcidin is the major predictor of erythrocyte iron incorporation in anemic African children. Blood 119: 1922-1928.

19. Theurl I, Schroll A, Nairz M, Seifert M, Theurl M, et al. (2011) Pathways for the regulation of hepcidin expression in anemia of chronic disease and iron deficiency anemia in vivo. Haematologica 96: 1761-1769.

20. Leong W-I, Lönnerdal B (2004) Hepcidin, the Recently Identified Peptide that Appears to Regulate Iron Absorption. The Journal of Nutrition 134: 1-4.

21. Liu Q, Davidoff O, Niss K, Haase VH (2012) Hypoxia-inducible factor regulates hepcidin via erythropoietin-induced erythropoiesis. The Journal of Clinical Investigation 122: 4635-4644.

22. De Domenico I, Ward DM, Kaplan J (2011) Hepcidin and Ferroportin: The New Players in Iron Metabolism. Semin Liver Dis 31: 272-279.

23. Ramey G, Deschemin J-C, Durel B, Canonne-Hergaux F, Nicolas G, et al. (2010) Hepcidin targets ferroportin for degradation in hepatocytes. Haematologica 95: 501-504.

24. Luo X, Jiang Q, Song G, Liu Y-L, Xu Z-G, et al. (2012) Efficient oxidative folding and site-specific labeling of human hepcidin to study its interaction with receptor ferroportin. FEBS Journal: 3166-3175.

25. Preza GC, Ruchala P, Pinon R, Ramos E, Qiao B, et al. (2011) Minihepcidins are rationally designed small peptides that mimic hepcidin activity in mice and may be useful for the treatment of iron overload. The Journal of Clinical Investigation 121: 4880-4888.

26. Knutson MD, Oukka M, Koss LM, Aydemir F, Wessling-Resnick M (2005) Iron release from macrophages after erythrophagocytosis is up-regulated by ferroportin 1 overexpression and down-regulated by hepcidin. Proceedings of the National Academy of Sciences of the United States of America 102: 1324-1328. 
27. Ramey G, Deschemin JC, Durel B, Canonne-Hergaux F, Nicolas G (2010) Hepcidin targets ferroportin for degradation in hepatocytes. Haematologica 95: 501-504.

28. Pietrangelo A (2004) Hereditary Hemochromatosis — A New Look at an Old Disease. New England Journal of Medicine 350: 2383-2397.

29. D'Alessio F, Hentze MW, Muckenthaler MU (2012)The hemochromatosis proteins hfe, tfr2 and hjv form a membrane-associated protein complex For hepcidin regulation. Journal of Hepatology 57: 1052-1060.

30. Pietrangelo A, Camaschella C (1998) Molecular genetics and control of iron metabolism in hemochromatosis. Haematologica 83: 456-461.

31. Fleming RE, Sly WS (2002) Mechanisms of iron accumulation in hereditary hemochromatosis. Annual Review of Physiology 64: 663-680.

32. Cohen AR, Glimm E, Porter JB (2008) Effect of transfusional iron intake on response to chelation therapy in $\beta$-thalassemia major. Blood 111: 583-587.

33. Tung BY, Emond MJ, Bronner MP, Raaka SD, Cotler SJ, et al. (2003) Hepatitis C, iron status, and disease severity: Relationship with HFE mutations. Gastroenterology 124: 318-326.

34. Friedman IM, Kraemer HC, Mendoza FS, Hammer LD (1988) Elevated serum iron concentration in adolescent alcohol users. Am J Dis Child 142: 156-159.

35. Porter JB (2001) Practical management of iron overload. British Journal of Haematology 115: 239-252.

36. Finberg KE (2009) Iron-Refractory Iron Deficiency Anemia. Seminars in Hematology 46: 378-386.

37. Feder JN (1996) A novel MHC class I - like gene is mutated in patients with hereditary hemochromatosis. Nat Genet 13: 399-408.

38. Merryweather-Clarke AT, Pointon JJ, Shearman JD, Robson KJ (1997) Global prevalence of putative haemochromatosis mutations. Journal of Medical Genetics 34: $275-278$.

39. European Association for the Study of the L (2010) EASL clinical practice guidelines for HFE hemochromatosis. Journal of Hepatology 53: 3-22.

40. McLaren GD, Gordeuk VR (2009) Hereditary hemochromatosis: insights from the Hemochromatosis and Iron Overload Screening (HEIRS) Study. ASH Education Program Book 2009: 195-206. 
41. Nadakkavukaran IM, Gan EK, Olynyk JK (2012) Screening for hereditary haemochromatosis. Pathology - Journal of the RCPA 44: 148-152.

42. Olynyk JK, Cullen DJ, Aquilia S, Rossi E, Summerville L, et al. (1999) A PopulationBased Study of the Clinical Expression of the Hemochromatosis Gene. New England Journal of Medicine 341: 718-724.

43. Ajioka RS, Levy JE, Andrews NC, Kushner JP (2002) Regulation of iron absorption in Hfe mutant mice. Blood 100: 1465-1469.

44. Bacon B (1999) Molecular medicine and hemochromatosis: at the cross road. gastroenterology 116: 193-207.

45. Risch N (1997) Haemochromatosis, HFE and genetic complexity. Nat Genet 17: 375376.

46. Nelson JE, Bhattacharya R, Lindor KD, Chalasani N, Raaka S, et al. (2007) HFE C282Y mutations are associated with advanced hepatic fibrosis in Caucasians with nonalcoholic steatohepatitis. Hepatology 46: 723-729.

47. Moodie SJ, Ang L, Stenner JMC, Finlayson C, Khotari A, et al. (2002) Testing for haemochromatosis in a liver clinic population: relationship between ethnic origin, HFE gene mutations, liver histology and serum iron markers. European Journal of Gastroenterology \& Hepatology 14: 223-229.

48. Camashella (2000) The gene TFR2 is mutated in a new type of haemochromatosis mapping to 7q22. Nature Genetics 25: 14-15.

49. Chua ACG, Delima RD, Morgan EH, Herbison CE, Tirnitz-Parker JEE, et al. (2010) Iron uptake from plasma transferrin by a transferrin receptor 2 mutant mouse model of haemochromatosis. Journal of Hepatology 52: 425-431.

50. Pietrangelo A (2010) Hereditary Hemochromatosis: Pathogenesis, Diagnosis, and Treatment. Gastroenterology 139: 393-408.

51. Roetto A, Totaro A, Piperno A, Piga A, Longo F, et al. (2001) New mutations inactivating transferrin receptor 2 in hemochromatosis type 3. Blood 97: 25552560.

52. Roetto A, Totaro A, Cazzola M, Cicilano M, Bosio S, et al. (1999) Juvenile Hemochromatosis Locus Maps to Chromosome 1q. The American Journal of Human Genetics 64: 1388-1393. 
53. Roetto A, Daraio F, Porporato P, Caruso R, Cox TM, et al. (2004) Screening hepcidin for mutations in juvenile hemochromatosis: identification of a new mutation (C70R). Blood 103: 2407-2409.

54. Lesbordes-Brion J-C, Viatte L, Bennoun M, Lou D-Q, Ramey G, et al. (2006) Targeted disruption of the hepcidin 1 gene results in severe hemochromatosis. Blood 108: 1402-1405.

55. Montosi G, Donovan A, Totaro A, Garuti C, Pignatti E, et al. (2001) Autosomaldominant hemochrom-atosis is associated with a mutation in the ferroportin (SLC11A3) gene. The Journal of Clinical Investigation 108: 619-623.

56. Pietrangelo A (2004) The ferroportin disease. Blood Cells, Molecules, and Diseases 32: 131-138.

57. Pietrangelo A (2004) Non-HFE hemochromatosis. Hepatology 39: 21-29.

58. Galanello R, Origa R (2010) Beta-thalassemia. Orphanet $\mathrm{J}$ Rare Dis 21: 5- 11.

59. Higgs DR, Engel JD, Stamatoyannopoulos G Thalassaemia. The Lancet 379: 373-383.

60. Papanikolaou G, Pantopoulos K (2005) Iron metabolism and toxicity. Toxicology and Applied Pharmacology 202: 199-211.

61. Ginzburg Y, Rivella S (2011) $\beta$-thalassemia: a model for elucidating the dynamic regulation of ineffective erythropoiesis and iron metabolism. Blood.

62. Lee PL, Beutler E (2009) Regulation of Hepcidin and Iron-Overload Disease. Annual Review of Pathology: Mechanisms of Disease 4: 489-515.

63. Nai A, Pagani A, Mandelli G, Lidonnici MR, Silvestri L, et al. (2012) Deletion of TMPRSS6 attenuates the phenotype in a mouse model of $\beta$-thalassemia. Blood 119: 5021-5029.

64. Mueller S, Millonig G, Seitz HK (2009) Alcoholic liver disease and hepatitis C: a frequently underestimated combination. World J Gastroenterol 15: 3462-3471.

65. Bridle KR, Cheung T-K, Murphy TL, Walters MM, Anderson GJ, et al. (2006) Hepcidin Is Down-regulated in Alcoholic Liver Injury: Implications for the Pathogenesis of Alcoholic Liver Disease. Alcoholism: Clinical and Experimental Research 30: 106-112.

66. Harrison-Findik DD, Klein E, Crist C, Evans J, Timchenko N, et al. (2007) Ironmediated regulation of liver hepcidin expression in rats and mice is abolished by alcohol. Hepatology 46: 1979-1985. 
67. Harrison-Findik DD, Schafer D, Klein E, Timchenko NA, Kulaksiz H, et al. (2006) Alcohol Metabolism-mediated Oxidative Stress Down-regulates Hepcidin Transcription and Leads to Increased Duodenal Iron Transporter Expression. Journal of Biological Chemistry 281: 22974-22982.

68. Wu D, Cederbaum AI (2009) Oxidative Stress and Alcoholic Liver Disease. Semin Liver Dis 29: 141-154.

69. Kohgo Y, Ikuta K, Ohtake T, Torimoto Y, Kato J (2007) Iron overload and cofactors with special reference to alcohol, hepatitis $\mathrm{C}$ virus infection and steatosis/insulin resistance. World J Gastroenterol 13: 4699-4706.

70. Ma Y-S, Wu S-B, Lee W-Y, Cheng J-S, Wei Y-H (2009) Response to the increase of oxidative stress and mutation of mitochondrial DNA in aging. Biochimica et Biophysica Acta (BBA) - General Subjects 1790: 1021-1029.

71. Aisen P, Enns C, Wessling-Resnick M (2001) Chemistry and biology of eukaryotic iron metabolism. Int J Biochem Cell Biol 33: 940-959.

72. De Domenico I, McVey Ward D, Kaplan J (2008) Regulation of iron acquisition and storage: consequences for iron-linked disorders. Nat Rev Mol Cell Biol 9: 72-81.

73. Aisen P (2004) Transferrin receptor 1. The International Journal of Biochemistry \&amp; Cell Biology 36: 2137-2143.

74. Kawabata H, Yang R, Hirama T, Vuong PT, Kawano S, et al. (1999) Molecular Cloning of Transferrin Receptor 2. A new member of the transferrin receptor-like family. J Biol Chem 274: 20826-20832.

75. Ikuta K, Yersin A, Ikai A, Aisen P, Kohgo Y (2010) Characterization of the Interaction between Diferric Transferrin and Transferrin Receptor 2 by Functional Assays and Atomic Force Microscopy. Journal of Molecular Biology 397: 375-384.

76. van Renswoude J, Bridges KR, Harford JB, Klausner RD (1982) Receptor-mediated endocytosis of transferrin and the uptake of fe in K562 cells: identification of a nonlysosomal acidic compartment. Proceedings of the National Academy of Sciences 79: 6186-6190.

77. Eckenroth BE, Steere AN, Chasteen ND, Everse SJ, Mason AB (2011) How the binding of human transferrin primes the transferrin receptor potentiating iron release at endosomal pH. Proceedings of the National Academy of Sciences 108: 13089-13094.

78. Luck AN, Mason AB (2012) Transferrin-mediated cellular iron delivery. Curr Top Membr 69: 3-35. 
79. Knutson MD (2007) Steap Proteins: Implications for Iron and Copper Metabolism. Nutrition Reviews 65: 335-340.

80. Mims MP, Prchal JT (2005) Divalent metal transporter 1. Hematology 10: 339-345.

81. Sipe D, Murphy R (1991) Binding to cellular receptors results in increased iron release from transferrin at mildly acidic pH. J Biol Chem 266: 8002-8007.

82. Brissot P, Ropert M, Le Lan C, Loréal O (2012) Non-transferrin bound iron: A key role in iron overload and iron toxicity. Biochimica et Biophysica Acta (BBA) - General Subjects 1820: 403-410.

83. Chua ACG, Olynyk JK, Leedman PJ, Trinder D (2004) Nontransferrin-bound iron uptake by hepatocytes is increased in the Hfe knockout mouse model of hereditary hemochromatosis. Blood 104: 1519-1525.

84. Trinder D, Oates PS, Thomas C, Sadleir J, Morgan EH (2000) Localisation of divalent metal transporter 1 (DMT1) to the microvillus membrane of rat duodenal enterocytes in iron deficiency, but to hepatocytes in iron overload. Gut 46: 270276.

85. Knöpfel M, Schulthess G, Funk F, Hauser H (2000) Characterization of an Integral Protein of the Brush Border Membrane Mediating the Transport of Divalent Metal Ions. Biophysical journal 79: 874-884.

86. Gehrke SG, Riedel H-D, Herrmann T, Hadaschik B, Bents K, et al. (2003) UbcH5A, a member of human E2 ubiquitin-conjugating enzymes, is closely related to SFT, a stimulator of iron transport, and is up-regulated in hereditary hemochromatosis. Blood 101: 3288-3293.

87. Scheiber-Mojdehkar B, Sturm B, Plank L, Kryzer I, Goldenberg H (2003) Influence of parenteral iron preparations on non-transferrin bound iron uptake, the iron regulatory protein and the expression of ferritin and the divalent metal transporter DMT-1 in HepG2 human hepatoma cells. Biochemical Pharmacology 65: 19731978.

88. Meyron-Holtz E, Moshe-Belizowski S, Cohen L (2011) A possible role for secreted ferritin in tissue iron distribution. Journal of Neural Transmission 118: 337-347.

89. Miyazaki E, Kato J, Kobune M, Okumura K, Sasaki K, et al. (2002) Denatured Hferritin subunit is a major constituent of haemosiderin in the liver of patients with iron overload. Gut 50: 413-419. 
90. Harrison PM, Arosio P (1996) The ferritins: molecular properties, iron storage function and cellular regulation. Biochimica et Biophysica Acta (BBA) - Bioenergetics 1275: 161-203.

91. Graham RM, Chua AC, Herbison CE, Olynyk JK, Trinder D (2007) Liver iron transport. World J Gastroenterol 13: 4725-4736.

92. Drysdale J, Arosio P, Invernizzi R, Cazzola M, Volz A, et al. (2002) Mitochondrial Ferritin: A New Player in Iron Metabolism. Blood Cells, Molecules, and Diseases 29: $376-383$.

93. Ramm GA, Ruddell RG (2005) Hepatotoxicity of Iron Overload: Mechanisms of IronInduced Hepatic Fibrogenesis. Semin Liver Dis 25: 433-449.

94. Peters TJ, Seymour CA (1976) Acid hydrolase activities and lysosomal integrity in liver biopsies from patients with iron overload. Clin Sci Mol Med 50: 75-78.

95. Seymour CA, Peters TJ (1978) Organelle pathology in primary and secondary haemochromatosis with special reference to lysosomal changes. Br J Haematol 40: 239-253.

96. Kurz T, Terman A, Gustafsson B, Brunk U (2008) Lysosomes in iron metabolism, ageing and apoptosis. Histochemistry and Cell Biology 129: 389-406.

97. Iancu TC, Shiloh H (1994) Morphologic observations in iron overload: an update. Adv Exp Med Biol 356: 255-265.

98. Terman A, Brunk UT (2004) Lipofuscin. The International Journal of Biochemistry \&amp; Cell Biology 36: 1400-1404.

99. Kalyanaraman B (2007) Iron signaling and oxidant damage. Cardiovascular Toxicology 7: 92-94.

100. Galaris D, Pantopoulos K (2008) Oxidative Stress and Iron Homeostasis: Mechanistic and Health Aspects. Critical Reviews in Clinical Laboratory Sciences 45: 1-23.

101. Pietrangelo A (1996) Metals, Oxidative Stress, and Hepatic Fibrogenesis. Semin Liver Dis 16: 13-30.

102. Britton RS (1996) Metal-Induced Hepatotoxicity. Semin Liver Dis 16: 3-12.

103. Poli G (2000) Pathogenesis of liver fibrosis: role of oxidative stress. Molecular Aspects of Medicine 21: 49-98.

104. Hübscher SG (2003) Iron overload, inflammation and fibrosis in genetic haemochromatosis. Journal of Hepatology 38: 521-525. 
105. Pietrangelo A, Gualdi R, Casalgrandi G, Montosi G, Ventura E (1995) Molecular and cellular aspects of iron-induced hepatic cirrhosis in rodents. The Journal of Clinical Investigation 95: 1824-1831.

106. Penz-Österreicher M, Österreicher CH, Trauner M (2011) Fibrosis in Autoimmune and Cholestatic Liver Disease. Best Practice \&amp; Research Clinical Gastroenterology 25: 245-258.

107. Bataller R, Brenner DA (2005) Liver fibrosis. The Journal of Clinical Investigation 115: 209-218.

108. Hernandez-Gea V, Friedman SL (2011) Pathogenesis of Liver Fibrosis. Annual Review of Pathology: Mechanisms of Disease 6: 425-456.

109. Viatte L, Nicolas G, Lou D-Q, Bennoun M, Lesbordes-Brion J-C, et al. (2006) Chronic hepcidin induction causes hyposideremia and alters the pattern of cellular iron accumulation in hemochromatotic mice. Blood 107: 2952-2958.

110. Tao GZ, Li DH, Zhou Q, Toivola DM, Strnad P, et al. (2008) Monitoring of epithelial cell caspase activation via detection of durable keratin fragment formation. The Journal of Pathology 215: 164-174.

111. Wattiaux R, Wattiaux-De Coninck S, Ronveaux-dupal MF, Dubois F (1978) Isolation of rat liver lysosomes by isopycnic centrifugation in a metrizamide gradient. The Journal of Cell Biology 78: 349-368.

112. Strnad P, Tao GZ, Zhou Q, Harada M, Toivola DM, et al. (2008) Keratin Mutation Predisposes to Mouse Liver Fibrosis and Unmasks Differential Effects of the Carbon Tetrachloride and Thioacetamide Models. Gastroenterology 134: 11691179.

113. Desmet VJ, Gerber M, Hoofnagle JH, Manns M, Scheuer PJ (1994) Classification of chronic hepatitis: Diagnosis, grading and staging. Hepatology 19: 1513-1520.

114. Lunova M, Zizer E, Kucukoglu O, Schwarz C, Dillmann WH, et al. (2012) Hsp72 Overexpression Accelerates the Recovery from Caerulein-Induced Pancreatitis. PLoS ONE 7: e39972.

115. Walther P (2003) Cryo-Fracturing and Cryo-Planing for In-Lens Cryo-SEM, Using a Newly Designed Diamond Knife. Microscopy and Microanalysis 9: 279-285.

116. Rad AM, Janic B, Iskander AS, Soltanian-Zadeh H, Arbab AS (2007) Measurement of quantity of iron in magnetically labeled cells: comparison among different UV/VIS spectrometric methods. BioTechniques 43: 627-636. 
117. Gosriwatana I, Loreal O, Lu S, Brissot P, Porter J, et al. (1999) Quantification of Non-Transferrin-Bound Iron in the Presence of Unsaturated Transferrin. Analytical Biochemistry 273: 212-220.

118. Lebeau A, Frank J, Biesalski HK, Weiss G, Srai SKS, et al. (2002) Long-term sequelae of HFE deletion in C57BL/6 $\times 129 / \mathrm{O} 1 \mathrm{a}$ mice, an animal model for hereditary haemochromatosis. European Journal of Clinical Investigation 32: 603612.

119. Fleming RE, Holden CC, Tomatsu S, Waheed A, Brunt EM, et al. (2001) Mouse strain differences determine severity of iron accumulation in Hfe knockout model of hereditary hemochromatosis. Proceedings of the National Academy of Sciences 98: 2707-2711.

120. Kautz L, Meynard D, Besson-Fournier C, Darnaud V, Al Saati T, et al. (2009) $\mathrm{BMP} / \mathrm{Smad}$ signaling is not enhanced in Hfe-deficient mice despite increased Bmp6 expression. Blood 114: 2515-2520.

121. Ramos E, Kautz L, Rodriguez R, Hansen M, Gabayan V, et al. (2011) Evidence for distinct pathways of hepcidin regulation by acute and chronic iron loading in mice. Hepatology 53: 1333-1341.

122. Meynard D, Kautz L, Darnaud V, Canonne-Hergaux F, Coppin H, et al. (2009) Lack of the bone morphogenetic protein BMP6 induces massive iron overload. Nat Genet 41: 478-481.

123. Levy JE, Montross LK, Cohen DE, Fleming MD, Andrews NC (1999) The C282Y Mutation Causing Hereditary Hemochromatosis Does Not Produce a Null Allele. Blood 94: 9-11.

124. Valerio Jr LG, Petersen DR (2000) Characterization of Hepatic Iron Overload Following Dietary Administration of Dicyclopentadienyl Iron (Ferrocene) to Mice: Cellular, Biochemical, and Molecular Aspects. Experimental and Molecular Pathology 68: 1-12.

125. Dexter DT, Ward RJ, Florence A, Jenner P, Crichton RR (1999) Effects of desferrithiocin and its derivatives on peripheral iron and striatal dopamine and 5hydroxytryptamine metabolism in the ferrocene-loaded rat. Biochemical Pharmacology 58: 151-155.

126. Golberg L, Smith JP, Martin LE (1957) The effects of intensive and prolonged administration of iron parenterally in animals. Br J Exp Pathol 38: 297-311. 
127. Richter GW (1974) Effects of cyclic starvation-feeding and of splenectomy on the development of hemosiderosis in rat livers. Am J Pathol 74: 481-506.

128. Ramm GA (2000) Hemochromatosis: Cambridge University Press.

129. Moon S, Han J, Hwang H, Kim M, Lee S, et al. (2011) Establishment of Secondary Iron Overloaded Mouse Model: Evaluation of Cardiac Function and Analysis According to Iron Concentration. Pediatric Cardiology 32: 947-952.

130. Olynyk JK, Luxon BA, Britton RS, Bacon BR (1998) Hepatic iron concentration in hereditary hemochromatosis does not saturate or accurately predict phlebotomy requirements. Am J Gastroenterol 93: 346-350.

131. Bacon BR, Adams PC, Kowdley KV, Powell LW, Tavill AS (2011) Diagnosis and management of hemochromatosis: 2011 Practice Guideline by the American Association for the Study of Liver Diseases. Hepatology 54: 328-343.

132. Frazer DM, Anderson GJ, Ramm GA, Subramaniam VN, Powell LW (2008) How much iron is too much? Expert Review of Gastroenterology \& Hepatology 2: 287290.

133. Deugnier Y, Turlin B (2007) Pathology of hepatic iron overload. World J Gastroenterol 13: 4755-4760.

134. Ramm GA, Crawford DHG, Powell LW, Walker NI, Fletcher LM, et al. (1997) Hepatic stellate cell activation in genetic haemochromatosis: Lobular distribution, effect of increasing hepatic iron and response to phlebotomy. Journal of hepatology 26: 584-592.

135. Adams PC (1990) Hepatic iron in hemochromatosis. Dig Dis Sci 35: 690-692.

136. Adams PC (2001) Is there a threshold of hepatic iron concentration that leads to cirrhosis in C282Y hemochromatosis? Am J Gastroenterol 96: 567-569.

137. Waalen J, Felitti VJ, Gelbart T, Beutler E (2008) Screening for hemochromatosis by measuring ferritin levels: a more effective approach. Blood 111: 3373-3376.

138. Allen KJ, Bertalli NA, Osborne NJ, Constantine CC, Delatycki MB, et al. (2010) HFE Cys282Tyr homozygotes with serum ferritin concentrations below $1000 \mu \mathrm{g} / \mathrm{L}$ are at low risk of hemochromatosis. Hepatology 52: 925-933.

139. Jacobs EMG, Hendriks JCM, van Deursen CTBM, Kreeftenberg HG, de Vries RA, et al. (2009) Severity of iron overload of proband determines serum ferritin levels in families with HFE-related hemochromatosis: The HEmochromatosis FAmily Study. Journal of Hepatology 50: 174-183.

140. Pietrangelo A (2003) "Haemochromatosis.". Gut 52: ii23-ii30. 
141. Maxwell KL, Kowdley KV (2012) Metals and the liver. Current Opinion in Gastroenterology 28: 217-222.

142. Barton JC, Barton JC, Acton RT, So J, Chan S, et al. (2012) Increased Risk of Death From Iron Overload Among 422 Treated Probands With HFE Hemochromatosis and Serum Levels of Ferritin Greater Than $1000 \mu \mathrm{g} / \mathrm{L}$ at Diagnosis. Clinical gastroenterology and hepatology : the official clinical practice journal of the American Gastroenterological Association 10: 412-416.

143. Breuer W, Ronson A, Slotki IN, Abramov A, Hershko C, et al. (2000) The assessment of serum nontransferrin-bound iron in chelation therapy and iron supplementation. Blood 95: 2975-2982.

144. Delima RD, Chua ACG, Tirnitz-Parker JEE, Gan EK, Croft KD, et al. (2012) Disruption of hemochromatosis protein and transferrin receptor 2 causes ironinduced liver injury in mice. Hepatology 56: 585-593.

145. McNamara L, Macphail A, Mandishona E, Bloom P, Paterson A, et al. (1999) Nontransferrin-bound iron and hepatic dysfunction in African dietary iron overload. Journal of Gastroenterology and Hepatology 14: 126-132.

146. Brunt EM (2005) Pathology of Hepatic Iron Overload. Semin Liver Dis 25: 392-401.

147. Bridle KR, Crawford DHG, Fletcher LM, Smith JL, Powell LW, et al. (2003) Evidence for a sub-morphological inflammatory process in the liver in haemochromatosis. Journal of Hepatology 38: 426-433.

148. Ganz T (2012) Macrophages and Systemic Iron Homeostasis. Journal of Innate Immunity 4: 446-453.

149. Pietrangelo A (1998) Iron, oxidative stress and liver fibrogenesis. J Hepatol 1: 8-13.

150. Bhavnani M, Lloyd D, Bhattacharyya A, Marples J, Elton P, et al. (2000) Screening for genetic haemochromatosis in blood samples with raised alanine aminotransferase. Gut 46: 707-710.

151. Allen KJ, Gurrin LC, Constantine CC, Osborne NJ, Delatycki MB, et al. (2008) IronOverload-Related Disease in HFE Hereditary Hemochromatosis. New England Journal of Medicine 358: 221-230.

152. Lin E, Adams PC (1991) Biochemical liver profile in hemochromatosis. A survey of 100 patients. J Clin Gastroenterol 13: 316-320.

153. Philippe MA, Ruddell RG, Ramm GA (2007) Role of iron in hepatic fibrosis: one piece in the puzzle. World J Gastroenterol 13: 4746-4754. 
154. Takehara T, Tatsumi T, Suzuki T, Rucker Iii EB, Hennighausen L, et al. (2004) Hepatocyte-specific disruption of Bcl-xL leads to continuous hepatocyte apoptosis and liver fibrotic responses. Gastroenterology 127: 1189-1197.

155. Zhao M, Laissue JA, Zimmermann A (1997) Hepatocyte apoptosis in hepatic iron overload diseases. Histol Histopathol 12: 367-374.

156. Olynyk JK, Trinder D, Ramm GA, Britton RS, Bacon BR (2008) Hereditary hemochromatosis in the post-HFE era. Hepatology 48: 991-1001.

157. Gao B, Bataller R (2011) Alcoholic Liver Disease: Pathogenesis and New Therapeutic Targets. Gastroenterology 141: 1572-1585.

158. Hentze MW, Muckenthaler MU, Galy B, Camaschella C (2010) Two to Tango: Regulation of Mammalian Iron Metabolism. Cell 142: 24-38.

159. LeSage GD, Kost LJ, Barham SS, LaRusso NF (1986) Biliary excretion of iron from hepatocyte lysosomes in the rat. A major excretory pathway in experimental iron overload. The Journal of Clinical Investigation 77: 90-97.

160. Terman A, Kurz T (2012) Lysosomal Iron, Iron Chelation, and Cell Death. Antioxid Redox Signal 9: 9.

161. Myers BM, Prendergast FG, Holman R, Kuntz SM, LaRusso NF (1991) Alterations in the structure, physicochemical properties, and $\mathrm{pH}$ of hepatocyte lysosomes in experimental iron overload. The Journal of Clinical Investigation 88: 1207-1215.

162. Ward RJ, Florence AL, Baldwin D, Abiaka C, Roland F, et al. (1991) Biochemical and biophysical investigations of the ferrocene-iron-loaded rat. European Journal of Biochemistry 202: 405-410.

163. Stal P, Glaumann H, Hultcrantz R (1990) Liver cell damage and lysosomal iron storage in patients with idiopathic hemochromatosis. A light and electron microscopic study. J Hepatol 11: 172-180.

164. Iancu TC, Deugnier Y, Halliday JW, Powell LW, Brissot P (1997) Ultrastructural sequences during liver iron overload in genetic hemochromatosis. Journal of Hepatology 27: 628-638.

165. Peters TJ, Selden C, Seymour CA (1976) Lysosomal disruption in the pathogenesis of hepatic damage in primary and secondary haemochromatosis. Ciba Found Symp 9: 317-329.

166. Sebastiani G, Pantopoulos K (2011) Disorders associated with systemic or local iron overload: from pathophysiology to clinical practice. Metallomics 3: 971-986. 
167. Ganz T, Nemeth E (2012) Iron Metabolism: Interactions with Normal and Disordered Erythropoiesis. Cold Spring Harbor Perspectives in Medicine 2: a011668.

168. Ramm G, Ruddell R (2010) Iron homeostasis, hepatocellular injury, and fibrogenesis in hemochromatosis: the role of inflammation in a noninflammatory liver disease. Seminars in liver disease 30: 271-287.

169. Baumgartner HK, Gerasimenko JV, Thorne C, Ashurst LH, Barrow SL, et al. (2007) Caspase-8-mediated apoptosis induced by oxidative stress is independent of the intrinsic pathway and dependent on cathepsins. American Journal of Physiology Gastrointestinal and Liver Physiology 293: G296-G307.

170. Bröker LE, Huisman C, Span SW, Rodriguez JA, Kruyt FAE, et al. (2004) Cathepsin B Mediates Caspase-Independent Cell Death Induced by Microtubule Stabilizing Agents in Non-Small Cell Lung Cancer Cells. Cancer Research 64: 27-30.

171. Canbay A, Guicciardi ME, Higuchi H, Feldstein A, Bronk SF, et al. (2003) Cathepsin $\mathrm{B}$ inactivation attenuates hepatic injury and fibrosis during cholestasis. The Journal of Clinical Investigation 112: 152-159.

172. Moles A, Tarrats N, Fernández-Checa JC, Marí M (2009) Cathepsins B and D drive hepatic stellate cell proliferation and promote their fibrogenic potential. Hepatology 49: 1297-1307.

173. Platt FM, Boland B, van der Spoel AC (2012) Lysosomal storage disorders: The cellular impact of lysosomal dysfunction. The Journal of Cell Biology 199: 723734.

174. Subramanian K, Balch WE (2008) NPC1/NPC2 function as a tag team duo to mobilize cholesterol. Proceedings of the National Academy of Sciences 105: 15223-15224.

175. Beltroy EP, Richardson JA, Horton JD, Turley SD, Dietschy JM (2005) Cholesterol accumulation and liver cell death in mice with Niemann-Pick type C disease. Hepatology 42: 886-893.

176. Cluzeau CVM, Watkins-Chow DE, Fu R, Borate B, Yanjanin N, et al. (2012) Microarray expression analysis and identification of serum biomarkers for Niemann-Pick disease, type C1. Human Molecular Genetics 21: 3632-3646.

177. Alam MS, Getz M, Safeukui I, Yi S, Tamez P, et al. (2012) Genomic Expression Analyses Reveal Lysosomal, Innate Immunity Proteins, as Disease Correlates in Murine Models of a Lysosomal Storage Disorder. PLoS ONE 7: e48273. 
178. Iancu TC, Neustein HB, Landing BH (1976) The liver in thalassaemia major: ultrastructural observations. Ciba Found Symp 9: 293-316.

179. Svegliati Baroni G, D'Ambrosio L, Ferretti G, Casini A, Di Sario A, et al. (1998) Fibrogenic effect of oxidative stress on rat hepatic stellate cells. Hepatology 27: 720-726.

180. Yachie A, Niida Y, Wada T, Igarashi N, Kaneda H, et al. (1999) Oxidative stress causes enhanced endothelial cell injury in human heme oxygenase-1 deficiency. The Journal of Clinical Investigation 103: 129-135. 


\section{Curriculum Vitae}

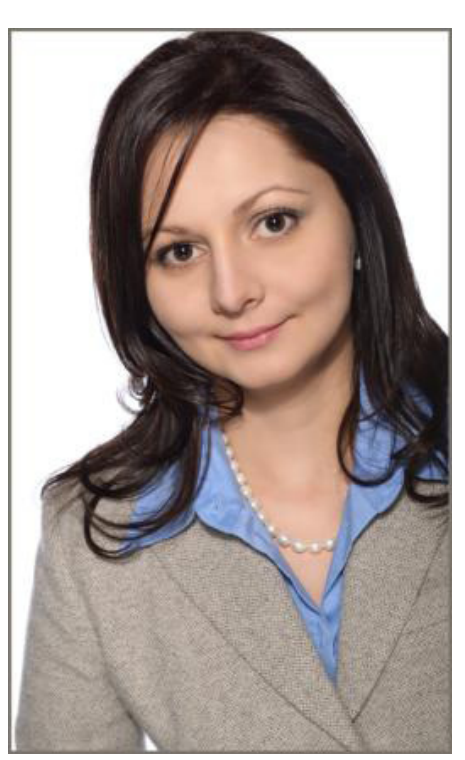

Name:

Lunova, Mariia

Current Position: Ph.D student in the group of PD Dr. Pavel Strnad

Birth date:

July 13, 1985

Working address: Clinic for Internal Medicine,

University Hospital Ulm

Albert Einstein Allee 23,

D-89081 Ulm, Germany

Telefone:

working +49 (731) 500-44 553

Mobile +49176 63849590

\section{Education}

6/2009-

present Ph.D student in Clinic for Internal Medicine I Ulm, Internal medicine I, AG Strnad.

2/2009-6/2009 Volunteered in Institute of Natural Products and Clinical Pharmacology.

2007-12/2008 Worked in Ukraine as leading analyst of research laboratory at the plant "Artemovsk Winery".

Master Degree in Chemical Sciences, Donetsk National University, Department of Organic Chemistry, Donetsk, Ukraine.

Bachelor Degree in Chemical Sciences. Donetsk National University, Department of Organic Chemistry, Donetsk, Ukraine.

2002-2007 Student of Chemical faculty of Donetsk National University, Department of Organic Chemistry.

2002

Graduation in natural sciences class of secondary school №5

Artemosk, Ukraine.

\section{Working experience}

2009-

present $\mathrm{PhD}$ student in Clinic for Internal Medicine I Ulm

$2 / 2009$

Volunteered in Institute of Natural products and clinical

Pharmacology, Ulm. 
2007-2008

Leading analyst of research laboratory at the plant "Artemovsk Winery", Artemovsk, Ukraine.

2006

Analyst of the research laboratory in research institute "Institute of physic and organic chemistry" department of "Physic and organic carbon compounds"”, Donetsk, Ukraine.

2005 Analyst of laboratory of the confectionery "Kiev-Konty", Donetsk,

Ukraine.

\section{Honors and Awards}

2013

Fellowship, 48th Annual Meeting of the European Association for the Study of the Liver, Amsterdam, Netherlands

Honored member of EASL society 2013

2012

Fellowship, 47th Annual Meeting of the European Association for the Study of the Liver, Barcelona, Spain

2012 Honoured member of EASL society 2012

2012

Honoured member of Hepatology society 2012

2011

Fellowship, "The Role of Notch Signalling, Intermediate Filaments and Cell Vesicle Trafficking in Cell Differentiation', Sweeden

Award "Best Scientific Work of University Students", The National Academy of Sciences of Ukraine

2001

Winner "Scientific Works in Medicine", High School Student Competition of all secondary schools of Ukraine

\section{Research Interests}

- To study the relationship between human disorders and animal models of liver disease, pancreatitis, and colitis, using different animal models, to find the potential mechanisms and corresponding treatments.

- Clinical studies of genetic disorders. Genetic mutations in human iron overload diseases

- The role of hepcidin in liver iron metabolism

- The role of heat shock proteins on pancreatitis and inflammatory liver diseases

\section{Publications}

1. Usachov V, Nahon P, Lunova M, Ziol M, Rufat P, Sutton A, Beaugrand M, Strnad P. Keratin 8 variants are infrequent in patients with alcohol-related liver cirrhosis and do not associate with development of hepatocellular carcinoma. BMC Gastroenterol. 2012 Oct $18 ; 12(1): 147$. 
2. Lunova M, Zizer E, Kucukoglu O, Schwarz C, Dillmann WH, Wagner M, Strnad P. Hsp72 overexpression accelerates the recovery from caerulein-induced pancreatitis. PLoS One. 2012;7(7):e39972. Epub 2012 Jul 5.

3. Strnad P, Kucukoglu O, Lunova M, Guldiken N, Lienau TC, Stickel F, Omary MB. Non-coding keratin variants associate with liver fibrosis progression in patients with hemochromatosis. PLoS One. 2012;7(3):e32669. Epub 2012 Mar 7.

4. M Lunova, S Vaulont, J Haybaeck, C. Lackner, P Strnad. Hepcidin knockout mice as a model of iron - overload associated liver fibrosis development. Journal of Hepatology vol. 56 April, 2012. p. S154-S155

5. M. Lunova, S Vaulont, J Haybaeck, C. Lackner, P Strnad. Hepcidin knockout mice as a model of iron-overload associated liver disease. Hepatology. 2011; volume 54, Suplement:1, pages: 928A-928A.

\section{Selected presentations}

1. M. Lunova, U. Wilgelmson, M. Pekny, P.Strnad. 'Loss of GFAP / Vimentin protects from DSS - induced colitis. The Role of Notch Signaling, Intermediate Filaments and Cell Vesicle Trafficking in Cell Differentiation’, GOTEBORG 2011

2. M. Lunova, K. Mueller, S. Vaulont, J. Haybaeck, C. Lackner, C. Trautwein, P. Strnad. "Hepcidin knockout mice develop chronic liver injury and liver fibrosis as a consequence of lysosomal iron overload", EASL 2013, Amsterdam, Netherlands

\section{Selected posters}

1. M. Lunova, K. Mueller, S. Vaulont, J. Haybaeck, C. Lackner, C. Trautwein, P. Strnad. Hepcidin knockout mice develop chronic liver injury and liver fibrosis as a consequence of lysosomal iron overload. GASL 2013, Hannover

2. M Lunova, S Vaulont, J Haybaeck, C. Lackner, P Strnad. Hepcidin knockout mice as a model of iron-overload associated liver disease. GASL 2012

3. M. Lunova, S Vaulont, J Haybaeck, C. Lackner, P Strnad. Hepcidin knockout mice as a model of iron-overload associated liver disease. Gastroenterologie, Viszeralchirurgie, Viszeralmedizin, 14-17 September 2011, Leipzig

4. M. Lunova, S Vaulont, J Haybaeck, C. Lackner, P Strnad. Hepcidin knockout mice as a model of iron-overload associated liver disease. GASL 2011

5. M. Lunova, U. Wilgelmson, M. Pekny, P.Strnad. 'Loss of GFAP / Vimentin protects from DSS - induced colitis. The Role of Notch Signaling, Intermediate Filaments and Cell Vesicle Trafficking in Cell Differentiation', GOTEBORG 2011 
6. Pavel Strnad, Özlem Kücükoglu, Mariia Lunova, Tim C. Lienau, Felix Stickel, M. Bishr Omary. "Non-coding keratin variants associate with fibrosis progression in hemochromatosis patients. GASL 2011

7. M. Lunova, Özlem Kücükoglu, Eugen Zizer, Guido Adler, Martin Wagner, Pavel Strnad. Genetic Hsp72 overexpression accelerates recovery from caerulein-induced pancreatitis. Inflammatory Mechanisms and Functional Gastrointestinal Diseases: Implications for Pathophysiology, Diagnosis and Therapy, June 4th-5th, 2010, Berlin

8. P. Strnad, O. Kucukoglu, M. Lunova, Tim C. Lienau, Felix Stickel, M. Bishr Omary. Keratin variants associate with fibrosis progression in hemochromatosis patients. January Amsterdam, 2010

\section{Reviewing work}

2012 reviewer in Journal of Experimental Lung Research

\section{Other activities}

2004-2007 Leader of the Students Scientific Association of the Faculty of Chemistry, Donetsk National University

2005 Part-time teacher of biology and chemistry, "Erydit" school, Donetsk, Ukraine

\section{Skils}

1. Extensive expertise in animal models of human gastroenterological diseases (liver, pancreas, colon)

2. Isolation of primary cells, work with cell culture

3. Nucleic acid methods: PCR and Q-PCR, DHPLC, analysing of microarray data

4. Biochemical assays: Western Blot, ELISA, MPO measurement, oxidative stress assays, XTT/MTT cytotoxicity, immunochistochemistry and immunofluorescence, histology staining (H\&E, Sirius Red, Prussian Blue), detection of iron and NonTransferinBound iron, subcellular fractionation.

5. Computer skills: MathCad, Statistica, Origin, HyperChem, ChemOffice, Sigma Plot, ImageJ, MS Office (MS-Word, MS- Excel, MS- Access, MS Power- Point etc.).

\section{Languages}

English (fluently), Russian (native), Ukrainian (native), German (limited speaking and writing skills). 


\section{References}

PD Dr. Pavel Strnad

Department of Medicine III,

University Hospital Aachen,

Aachen, Germany

Tel.: +49 0241-8035324

email : pstrnad@ukaachen.de

Prof Dr. Thomas Simmet

Institute of Natural Products

and Clinical Pharmacology

Helmholtzstraße 20 D-89081 Ulm

Tel: (0731) 500-65600 Fax: (0731) 500-65602

email: thomas.simmet@uni-ulm.de 


\section{Acknowledgments}

I could not imagine that time can go so fast and I am already writing this last chapter of my thesis. It would not have been possible to write this doctoral thesis without the motivation, help and support of the kind people around me.

First of all, I would like to thank my advisor PD Dr. Pavel Strnad for the great support, helpful guidance, motivation and patience all the time during my $\mathrm{PhD}$ work. His knowledge and advice have helped me to keep on track and work at a smooth pace.

I will newer forget huge help of Claudia Laengle, Caroline Schwarz and Claudia Goehring. In addition, I would like to thank to all of my colleagues which are still in Ulm (Nurdan, Özlem, Peggy, Elke, Anke and Katrin) and to colleagues which moved to Aachen (Kateryna, Yu Chen and Valentyn) for great time together.

I would like to thank to my family, which is now in Ukraine, and to my husband Oleg, for their understanding, patience and support.

I dedicate this thesis to my family (my husband Oleg, my mother Margarita, my father Victor and my brother Sergey) which was always with me and gave moral support. 